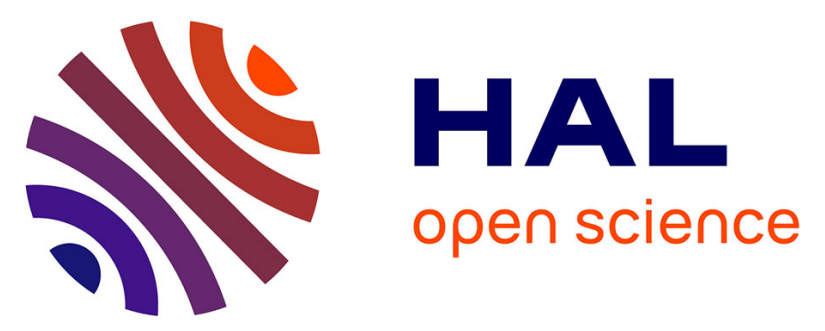

\title{
Late-Hercynian Intrusion-related gold deposits: an integrated model on the Tighza polymetallic district, central Morocco
}

Eric Marcoux, Khadija Nerci, Yannick Branquet, Claire Ramboz, Gilles Ruffet, Jean-Jacques Peucat, Ross Stevenson, Michel Jebrak

\section{To cite this version:}

Eric Marcoux, Khadija Nerci, Yannick Branquet, Claire Ramboz, Gilles Ruffet, et al.. Late-Hercynian Intrusion-related gold deposits: an integrated model on the Tighza polymetallic district, central Morocco. Journal of African Earth Sciences, 2015, 107, pp.65-88. 10.1016/j.jafrearsci.2015.01.011 . insu-01117246

\section{HAL Id: insu-01117246 \\ https://hal-insu.archives-ouvertes.fr/insu-01117246}

Submitted on 16 Feb 2015

HAL is a multi-disciplinary open access archive for the deposit and dissemination of scientific research documents, whether they are published or not. The documents may come from teaching and research institutions in France or abroad, or from public or private research centers.
L'archive ouverte pluridisciplinaire HAL, est destinée au dépôt et à la diffusion de documents scientifiques de niveau recherche, publiés ou non, émanant des établissements d'enseignement et de recherche français ou étrangers, des laboratoires publics ou privés. 


\section{Accepted Manuscript}

Late-Hercynian Intrusion-related gold deposits: an integrated model on the Tighza polymetallic district, central Morocco

Marcoux Éric, Nerci Khadija, Branquet Yannick, Ramboz Claire, Ruffet Gilles, Peucat Jean-Jacques, Stevenson Ross, Jebrak Micheld

PII:

S1464-343X(15)00019-9

DOI: http://dx.doi.org/10.1016/j.jafrearsci.2015.01.011

Reference: AES 2212

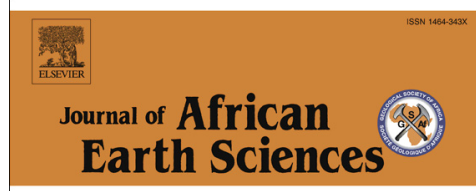

To appear in:

African Earth Sciences

Received Date:

29 September 2014

Revised Date:

26 January 2015

Accepted Date:

27 January 2015

Please cite this article as: Éric, M., Khadija, N., Yannick, B., Claire, R., Gilles, R., Jean-Jacques, P., Ross, S., Micheld, J., Late-Hercynian Intrusion-related gold deposits: an integrated model on the Tighza polymetallic district, central Morocco, African Earth Sciences (2015), doi: http://dx.doi.org/10.1016/j.jafrearsci.2015.01.011

This is a PDF file of an unedited manuscript that has been accepted for publication. As a service to our customers we are providing this early version of the manuscript. The manuscript will undergo copyediting, typesetting, and review of the resulting proof before it is published in its final form. Please note that during the production process errors may be discovered which could affect the content, and all legal disclaimers that apply to the journal pertain. 


\section{Late-Hercynian Intrusion-related gold deposits: an integrated model on the Tighza polymetallic district, central Morocco}

\section{Revised version for Journal of African Earth Sciences}

Monday, 9 February 2015

Marcoux Éric (1)

Nerci Khadija (2)

Branquet Yannick (1)

Ramboz Claire (1)

Ruffet Gilles (3)

Peucat Jean-Jacques (3)

Stevenson Ross (4)

Jébrak Michel (4)

(1) Université d'Orléans, Campus Géosciences, OSUC/ISTO, 1 A rue de la Férollerie, 45071 Orléans, France

(2) École Normale Supérieure Avenue Mohamed Belhassan El Ouazzani-Takaddoum BP 5118 Rabat, Maroc

(3) Géosciences Rennes, UMR CNRS 6118, Campus de Beaulieu, Université de Rennes1, 35042 Rennes Cedex, France

(4) Département des Sciences de la Terre et de l'Atmosphère, UQAM, CP 8888, centre-ville, Montréal, QC, H4A1N4, Canada

Corresponding author: eric.marcoux@univ-orleans.fr 


\section{Abstract}

Gold have been recently recognized in the Tighza (formerly Jebel Aouam) district, in the Hercynian belt of central Morocco. This district has long been known for its W mineralization, as well as major $\mathrm{Pb}-\mathrm{Ag}-\mathrm{Zn}$, and minor $\mathrm{Sb}-\mathrm{Ba}$ deposits, all geographically associated with lateHercynian calc-alkaline magmatism. Gold mineralization in the district is mainly hosted by thick W-Au quartz veins located around the "Mine granite" small granitic plug. Within the veins, gold grade is highest (up to $70 \mathrm{~g} / \mathrm{t}$ ) close to the granite but rapidly decreases going outward from the granite, defining a perigranitic zoning. Anomalous gold grades have also been measured in hydrothermal skarn layers close to two other granitic plugs (Kaolin granite and Mispickel granite), associated with disseminated As-Fe sulfides. The paragenetic sequence for the W-Au quartz veins shows three stages: 1) an early oxidized stage with wolframite-scheelite associated with early quartz $\left.\left(\mathrm{Q}_{1}\right), 2\right)$ an intermediate $\mathrm{Bi}-\mathrm{As}-\mathrm{Te}-\mathrm{Mo}-\mathrm{Au}$ sulfide stage with loellingite, bismuth minerals and native gold with a later quartz $\left(\mathrm{Q}_{2}\right)$, restricted to a narrow distance from the granite, and 3) a late lower temperature As-Cu- $\mathrm{Zn}-(\mathrm{Pb})$ stage with abundant massive pyrrhotite, arsenopyrite and sphalerite, locally forming independent veins ("pyrrhotite vein"). Both $\mathrm{Q}_{1}$ hyaline and $\mathrm{Q}_{2}$ saccharoidal gold-bearing quartz display aqua-carbonic fluids with minor $\mathrm{H}_{2} \mathrm{~S}$ and $\mathrm{Cu}$ and an homogeneous composition ( 81 mole $\% \mathrm{H}_{2} \mathrm{O}, 18$ mole $\% \mathrm{CO}_{2}$ and about 1 mole $\% \mathrm{NaCl}$ ). The trapping pressure is estimated to 1.5 to $2 \mathrm{kbar}$ with temperature ranging from $300^{\circ}$ to $350^{\circ} \mathrm{C}$. $\mathrm{Q}_{1}$ inclusions have exploded indicating an uplift of the Tighza block, that lead to saccharoidal $\mathrm{Q}_{2}$ quartz deposition with multiphase $\mathrm{NaCl}$-saturated fluid inclusions. ${ }^{40} \mathrm{Ar} /{ }^{39} \mathrm{Ar}$ dating demonstrates that the "Mine granite", tungsten skarnoid, scheelite-molybdenite veins, and very likely goldbearing veins are coeval, emplaced at $286 \pm 1$ Ma. Multiple and widespread metal sources are indicated by radiogenic isotope studies. $\mathrm{Nd}$ and $\mathrm{Sr}$ isotope compositions of scheelite and granites 
suggest the participation of a juvenile component while lead isotopes demonstrate a major participation of the basement.

Both gold mineralization and zoning suggest that the system developed at the end of the magmatic activity, accompanying a major transition in magmatic fluid composition. The morphology of the gold-bearing mineralization is dependent of the permeability and the reactivity of host-rocks: focus circulation of fluids through pre-existing tectonic corridors, reactivated by late-Hercynian intrusions favor the formation of large W-type gold veins, while infiltration of fluid within reactive stratigraphic layers gives rise to skarn mineralization. $\mathrm{A}{ }^{40} \mathrm{Ar} /{ }^{39} \mathrm{Ar}$ date (W1 north vein: $291.8 \pm$ $0.3 \mathrm{Ma}$ ) indicates that hydrothermal circulation predates gold and tungsten deposition in open fractures as well as Mine granite emplacement.

The $\mathrm{W}-\mathrm{Au}$ mineralization preceded the onset of a large convective hydrothermal cell around the intrusion that led to the formation of the $\mathrm{Pb}-\mathrm{Ag}-\mathrm{Zn}$ mined veins. The Tighza polymetallic district displays numerous similarities with the R-IRG model that was defined in the American Cordillera, such as thermal and zonation patterns, carbonic hydrothermal fluids and chronology of intrusion and related deposits, but also provides new insight to the R-IRG model such as wide Au-quartz veins instead of sheeted Au-veins, oxidation state of the magma, and $\mathrm{Sr}-\mathrm{Nd}$ isotopic data. These results establish a major magmatic contribution and discard a direct genetic relationship between gold mineralization and major neighboring $\mathrm{Pb}-\mathrm{Ag}-\mathrm{Zn}$ veins. A large number of classic $\mathrm{Pb}-\mathrm{Zn}$ district of the Western Hercynides belong to the same clan.

Keywords: gold, R-IRG, Tighza, Morocco, Hercynian, perigranitic 


\section{1 - Introduction}

The strong demand for gold and the maturity of several major mining districts have prompted new research on gold deposits associated with plutonic systems. Three main gold deposit types include: (1) porphyry copper-gold (Sillitoe, 2000); (2) Reduced intrusion-related gold (Lang and Baker, 2001); and (3) Iron Oxide Copper Gold deposits (Groves et al., 2010). Reduced Intrusion-related gold deposits (R-IRG) have been mainly described in the American Cordillera, and especially in the Tintina belt, such as the Fort Knox and Dublin Gulch deposits (Hollister, 1992; Sillitoe and Thompson, 1998; Thompson et al., 1999, Hart, 2005). They were previously described under the name of Thermal Aureole Gold (Wall and Taylor, 1991). The R-IRG type has been extended to the late Paleozoic Tianshan deposits, such as Muruntau, Vasilkovskoye, Amantaitau, and Kumtor), not without some controversies (Mao et al., 2004; Morelli et al., 2007). Several European gold deposits of the Hercynian belt have also been associated with the R-IRG type, such as the Mokskro (Czech Republic), Salsigne (France) and Rio Narcea (Spain) (Lang et al., 2000), and define a major metallogenic event around $300 \mathrm{Ma}$ (Gloaguen et al., 2003; Bouchot et al., 2005).

R-IRG deposits are characterized by: (1) a location within a deformed shelf sequence; (2) an association with relatively reduced plutons, of calc-alkaline composition, transitional between ilmenite and magnetite series with Sn-W mineralization; (3) a post-deformation emplacement, like orogenic gold deposits; (4) a low sulfide content, and 5) an association of proximal gold ore with distal base metal-rich veins. Fluids associated with the gold mineralization are $\mathrm{CO}_{2}$-rich hydrothermal fluids carrying Au, Bi, W, As, Mo, Te, and/or Sb (Hart, 2005). The genesis of these deposits remains, however, poorly understood. The limit of this new family of deposits, as the concept is more and more used outside its early definition. Major uncertainties remain concerning the genetic link between intrusion and mineralization including: i) the origin of fluids and 
elements, coming from the mantle or the crust, derived from magmas or by convection in the host rocks, ii) the thermal role of intrusion and the duration of the hydrothermal stage; iii) the connection between gold and associated ore deposits. The main objective of this paper is to better constrain the R-IRG model based on the example of the classic lead-zinc-silver Tighza mining district (formerly Jebel Aouam, Central Morocco Massif) where gold was recently discovered.

The Central Morocco Massif is the largest outcropping segment of the Hercynian belt in Morocco. It is part of the large Variscan belt of the Circum-Atlantic regions extended over $6000 \mathrm{~km}$ long between the Laurasia and Gondwana super-continents (Michard et al., 2010). It displays mainly Paleozoic rocks folded and locally thrust toward the West, cut by Late Carboniferous granitic massifs. Numerous mineral deposits have been mined, including tin and tungsten (Oulmes; Tahiri et al., 2007), fluorite (El Hammam), and lead-zinc-silver in Tighza (Agard et al., 1958; Jébrak, 1984; Cheilletz, 1984). After more than 40 years of Pb-Ag-Zn mining (6 Mt @ $8 \% \mathrm{~Pb}$, plus Ag and Zn; Wadjinny, 1998), gold was discovered in the Tighza district using drillings and limited underground workings. The Tighza gold mineralization provides details of the early metallogenic processes that occur in association with calc-alkaline plutonism in an I-IRG system. These metallogenic processes are studied by integrating field observations, detailed mineralogy, fluid inclusion and isotopic data within the structural evolution framework of the area at the end of the pluton emplacement.

\section{2 - Geology and ore deposits of the Tighza district}

\section{1 - Geology}

The Central Morocco Massif belongs to the Meseta domain of the Hercynian belt. This domain results from the Late Devonian-Late Carboniferous accretion of several Paleozoic sub-domains 
that reflect the development of a passive margin on the edge of the African craton during Early Paleozoic. Tighza is located in Ordovician to Carboniferous sedimentary units of the Nappe zone of eastern Central Morocco (Piqué et al., 1993). Tectonic shortening of the units during the Late Visean-Early Namurian occurred in association with the emplacement of gravity-driven synsedimentary nappes. Tectonic vergency is dominantly toward the WNW, with upright or NWverging folds associated with flat-ramp faults (Michard et al., 2010).

The Central Morocco Massif is crosscut by dextral transpressional NE-SW faults of Carboniferous to Permian in age that controlled the location of granodioritic intrusions and subsequently, the location of detrital basins. The granodioritic intrusions are interpreted to have formed from mixing between anatectic magmas derived from partial melting of continental crust and mantle-derived magmas (Gasquet et al., 1996; El Hadi et al., 2006). The intrusions were emplaced at supracrustal levels as late-tectonic elongated massifs between the Visean-Autunian period (ca 330 to 300-290 Ma). Late activation on the NE-SW faults resulted in the formation of pull-apart basins (Saidi et al., 2002) and associated alkaline felsic volcanism (Mrini et al., 1992). To our knowledge, no lowangle normal fault accommodating the collapse of the orogeny has yet been recognized.

In the Tighza area, upper Ordovician units are mainly detrital and composed of micaceous shales, with beds of sandstone, grading into quartzite units associated with fine conglomerates. Silurian sequences are composed of clay-rich detrital units and limestone. The amount of calcareous sedimentation increased during Early and Middle Devonian time. Above a regional unconformity (Fig. 1), Tournaisian sandstones (360 - $350 \mathrm{Ma}$ ) conglomerates, and greywackes are overlain by marine sedimentary rocks including Middle Visean bioclastic limestones and marls ( $340 \mathrm{Ma})$ and a thick pile of Visean-age flysch. 
Figure 1- Location and geology of the Tighza mining district with its various ore deposits

Late to post-Hercynian felsic intrusions can be divided in three groups (Cheilletz, 1984, Ntarmouchant, 1991): (1) an early calc-alkaline magmatic suite, composed of dikes of microgranodiorite, microgranite and rhyolite, with biotite granitic/granodioritic stocks, dated between $293.0 \pm 3.0$ and $287.9 \pm 5.1 \mathrm{Ma}$; (2) late tholeiitic microdioritic and microtonalitic dikes; and (3) sparse leucogranitic dikes.

Granitic stocks of the first group are mainly represented by three small bodies, about $1 \mathrm{~km}^{2}$ each, called from north to south: Mispickel granite (also named Bou-Iqualouchène), Mine granite, and Kaolin granite (Fig. 1). Although they appear slightly different in composition, these granitic stocks are considered as apexes of a larger magmatic body at depth (Agard et al., 1958; Eldursi, 2009; Branquet et al., in prep.). A broad zone of contact metamorphism (3 x $2 \mathrm{~km}$ on surface, Fig. 1) includes the three granite stocks supporting the presence of a unique magmatic body at depth.

Contact metamorphism is marked by the transformation of pelitic sediments to spotted hornfels showing a quartz, biotite, muscovite, andalusite and cordierite association. These mineral assemblages suggest a maximum temperature of $650^{\circ} \mathrm{C}$, with a lithostatic pressure around $2 \mathrm{kbar}$ (Cheilletz and Giuliani, 1988). Locally, small-sized skarns are enriched in scheelite in Visean and Ordovician carbonate layers.

The low $\mathrm{Fe}^{3+} /\left(\mathrm{Fe}^{3+}+\mathrm{Fe}^{2+}\right)$ ratios for the three granite (Table 1), their relative high modal amount of primary sulfides and the lack of primary magnetite (Nerci, 2006), suggest that they belong to the S-type granites of the ilmenite series (Whalen and Chapell, 1988) However, on a regional scale, Giuliani et al. (1989) show that the Jebel Aouam plutons, such as the Zaer biotite granodiorite unit 
west of the Tighza area, have geochemical characteristics characteristic of a mixture of felsic (crustal) and mafic (mantle) sources. Based on geochemistry and other arguments, Giuliani et al. (1989) qualified this calc-alkaline suite as a "post collisional, uplift environment" type.

Tholeiitic microdioritic dikes of the second group crosscut the $\mathrm{W}$ mineralized veins without movement along strike, but do not cross the $\mathrm{Pb}-\mathrm{Ag}-\mathrm{Zn}$ veins. Their orientation is compatible with the late tectonic event recorded throughout the area (D3 event, see below). The dikes correspond to a tholeiitic series with a calc-alkaline component that has no clear genetic relationships with other magmatic rocks of the Moroccan Central Massif (Ntarmouchant, 1991).

Dikes of leucogranites from silico-aluminous magmatic suites have been reported in the Tighza area (Ntarmouchant, 1991). These dikes postdate the calc-alkaline suite and are likely correlated to numerous and widespread two-mica granites in Central Morocco (e.g. the Zaer two-mica granite unit, the peraluminous Oulmès granite; Giuliani et al., 1989) derived from partial melting of metasediments after crustal thickening (i.e. S-type granites).

The structural evolution of the district has been deciphered by Desteucq (1974), Cheilletz (1983), and Branquet et al. (in prep.). Three main deformation events can be distinguished:

i) A thin-skinned event (D1) leading to the stacking of an allochtonous thrust sheet unit to the east over a relative autochthonous unit to the west (Fig. 1). Sparse stretching lineations along the sole thrust suggest that the transport direction is NE-SW;

ii) A ductile-brittle event associated with a NW-SE horizontal shortening (D2). This deformation is responsible for the NE-SW folding and related cleavage development which characterizes the present-day structure of the area. Reverse limbs also formed 
during this shortening event. E-W fractures and veins (such as the W1) and the major Tighza fault (Fig. 1) formed as oblique-slip dextral normal faults and hybrid extensional-shear- fractures (Branquet et al. in prep.). Tighza granitic stocks are associated with the D2 event, and thus D2 happened at about 290 Ma.

iii) Stress variations lead to a late brittle transtensive left-lateral wrenching event (D3) that is documented along the Tighza fault and compatible with the formation of the Pb-Ag$\mathrm{Zn}$ vein system (Desteucq, 1974; Cheilletz, 1983). A ${ }^{40} \mathrm{Ar} /{ }^{39} \mathrm{Ar}$ age of $205 \pm 1 \mathrm{Ma}$ is indicated based on dating of contemporaneous major fluorite deposits in the region such as El Hammam (Cheilletz et al., 2010). However, in the Central Morocco Massif, isotopic systems have been strongly reset by several thermal events related to the opening of the Atlantic Ocean (Jébrak, 1984; Ghorbal et al., 2008; Barbero et al., 2011) invoking a note caution in the interpretation of radiometric ages of weak minerals associated with the vein mineralization.

\section{2 - Mineral Deposits}

The Tighza district displays three types of mineral deposits: i) W-Au occurrences in the core of the district; ii) Widely distributed and exploited $\mathrm{Pb}-\mathrm{Ag}-\mathrm{Zn}$ veins (Sidi Ahmed, Signal, Ighem Aousser...); and iii) Sb-Ba veins, located at the periphery of the district (Figs. 1 and 2).

Figure 2 - Gold and tungsten-bearing structures of the Tighza mining district. See text for discussion 
Several large $\mathrm{Pb}-\mathrm{Ag}-\mathrm{Zn}$ vein deposits (Signal, Ighem Ousser, Sidi Ahmed...) striking N50 ${ }^{\circ}$ to $\mathrm{N} 80^{\circ} \mathrm{E}$ and dipping $\mathrm{N}$ to $\mathrm{NW}$ (average $65^{\circ}$ ) collectively contain more than $11 \mathrm{Mt}$ of ore, with $1 \mathrm{Mt}$ $\mathrm{Pb}$ and more than 1,000 $\mathrm{t} \mathrm{Ag}$ (Wadjinny, 1998), giving a grade of 9\% $\mathrm{Pb}$ and $90 \mathrm{~g} / \mathrm{t} \mathrm{Ag}$; zinc is now recovered since few years. They also yield significant amounts of zinc that was not recovered. The veins extend for more than $6 \mathrm{~km}$, with an average thickness of $2 \mathrm{~m}$, displaying pinch-andswell structures related to transtensional faulting. These veins are hosted by Paleozoic sediments, and cut across the granitic stocks (Kaolin and Mine granites) as well as tungsten veins (Desteucq, 1974). They are associated with conjugate strike-slip faults resulting from the NE-SW shortening (i.e. D3 event). An ${ }^{40} \mathrm{Ar} /{ }^{39} \mathrm{Ar}$ age of $267.7 \pm 2.3 \mathrm{Ma}$ was measured by Watanabe (2002) on hydrothermal illite from the Ighem Aousser vein. Two successive mineralization stages have been recognized: an early stage with siderite, quartz, silver-bearing galena, sphalerite, chalcopyrite, pyrite and traces of $\mathrm{Ni}, \mathrm{Sn}$ and $\mathrm{Bi}$ minerals, and a later stage with calcite, chalcedony, barite and less silver-rich galena, often exhibiting a banded texture, and collapse breccias (Jébrak, 1984).

Small silicified stibnite veins with barite are hosted by Paleozoic sediments in the outer parts of the district. They have been actively mined in the past, but are now not accessible. Dissemination of stibnite also appears in association within felsic dikes.

Tungsten-bearing mineral occurrences have been described by Cheilletz (1984) and Cheilletz and Isnard (1985) within the metamorphic aureole of the mine granite. Two types were distinguished (Figs. 1, 2 and 3):

- Stratabound, lens-shaped, skarnoid deposits in Ordovician terranes, with scheelite, Mgbiotite and quartz, only known at depth (Figs. $3 \mathrm{c}$ and $\mathrm{d}$ ): The association comprises actinolite, plagioclase, K-feldspar, pyrrhotite, chalcopyrite, ilmenite, sphalerite and titanite (Cheilletz and Giuliani, 1988). These skarns were interpreted to have resulted fromf 
metasomatic process induced by magmatic fluids (Cheilletz, 1984); they are crosscut by small dykes of diorite-tonalite of the late magmatic group, reflecting their early emplacement;

- Vein-type deposits that cross-cut the skarnoid deposits (Figs. 2 and 3) such as W1 tungsten and gold vein (see below).

Biotite from the $\mathrm{W} 1$ vein yielded ${ }^{40} \mathrm{Ar} /{ }^{39} \mathrm{Ar}$ ages of $288.4 \pm 3.1 \mathrm{Ma}$ and $285 \pm 3.8 \mathrm{Ma}$ whereas biotite from the stratabound lens-shaped skarnoids gave ages of $285.3 \pm 3 \mathrm{Ma}$ and $284.1 \pm 4.2 \mathrm{Ma}$ (Cheilletz et Zimmermann, 1982; Cheilletz, 1984), demonstrating their association with the first magmatic stage.

The T-P conditions of emplacement of these tungsten mineralization events were determined by fluid inclusion study to be $580^{\circ} \mathrm{C}$ and $1.8 \mathrm{kbar}$ for the stratabound lens-shaped skarnoids, and $400^{\circ}$ to $450^{\circ} \mathrm{C}$ and $1 \mathrm{kbar}$ for vein-style deposit (Cheilletz and Isnard, 1985). Skarnoids fluids were of moderate to high salinity (6-18 wt \% NaCl equiv.; Cheilletz and Giuliani, 1988).

\section{3 - Geology and mineralogy of gold deposits}

Although tungsten-bearing veins have been documented since mineral exploration of the district began 60 years ago, the potential for gold has only been recognized over the past 20 years. Gold occurrences have been discovered in i) tungsten-bearing quartz veins (the "W veins", ii) quartzscheelite stockwork, and iii) As-Fe-(Au) dissemination in Visean skarn (Figs. 2, 3).

\section{1 - Au-W quartz veins}


$\mathrm{Au}-\mathrm{W}$-bearing veins are found immediately adjacent to the Mine granite. They form a regular, locally anastomosed, network, with a strike varying from $\mathrm{N} 90^{\circ} \mathrm{E}$ to $\mathrm{N} 120^{\circ} \mathrm{E}$. Major veins include W1, W1 north, WO3, W4, W5 and W6 (Figs. 2, 3a). W1 north and W4 have been intersected in drill hole at depths of up to $220 \mathrm{~m}$. Their thickness reaches locally $2 \mathrm{~m}$. Two minor arsenopyrite veins, located at the southwestern edge of the Mispickel Granite, and a decimetric quartzscheelite-bismuth-molybdenite vein at level $707 \mathrm{~m}$ belong probably to the same $\mathrm{W}$ vein system (Fig. 2).

The largest vein system is the W1-W1 north vein that can be followed over a distance of $1400 \mathrm{~m}$. It dips $50^{\circ} \mathrm{N}$ to $85^{\circ} \mathrm{N}$, and displays a large virgation toward the north in it western part. From the contact with the Mine granite, the fracture continues within the granite. It appears as a microgranite dike with rhyolitic texture that was subsequently strongly silicified and sericitized and now appears as a greisen (Fig. 3f). This zone is meters thick, strikes N130 $\mathrm{E}$, and shows a significant gold enrichment ( $>0.4 \mathrm{ppm})$. The W1-W1 north vein system crosscuts rhyolitic dykes but is itself cut by dark tonalite dykes, and several dextral and sinistral wrench faults. On the south-east side of the Mine granite, two others veins (W4 and W5) display similar characteristics with a slightly different strike $\left(\mathrm{N} 125^{\circ} \mathrm{E}\right.$ for $\left.\mathrm{W} 4\right)$. The complex geometry of the $\mathrm{W}$ veins is indicative of a transtentional dextral fault systems with a horsetail pattern, a structure suggestive of fracture reactivation during NW-SE shortening.

The $\mathrm{W}$ veins are mainly composed of massive hyaline quartz, becoming white grey $(\mathrm{Q} 1)$ and then saccharoidal $\left(\mathrm{Q}_{2}\right)$ due to tectonic activity and new silica input. Quartz is associated with muscovite (W1-W1north) or biotite, phlogopite (WO3, W4 and W5), sulfides and native gold. Detailed gold analyses of the vein demonstrate a strong zoning: highest grades occur immediately near the Mine granite (up to $50 \mathrm{ppm}$ ), and decrease outward: 9 ppm from the contact to $200 \mathrm{~m}, 3 \mathrm{ppm}$ at $400 \mathrm{~m}$ 
(mean values) (Fig. 4). The highest grades have been measured in the W1 north near the granite (average grade of $4.36 \mathrm{ppm}$ on $500 \mathrm{~m}$ in surface, and $9.3 \mathrm{ppm}$ on $363 \mathrm{~m}$ starting from the granite), and in the WO3 (average $166 \mathrm{ppm}$ ).

Figure 3 - Rock Field exposures in Tighza mining district

a -W1 north Au-W quartz vein. Overburden was removed to allow a precise grab sampling, yielding the highest gold values of the district.

b - Scheelite-quartz stockwork within the Mine granite, near Signal shaft. Note the regularity of the veins systems.

c - Skarnoid with scheelite within layered Ordovician formations. Scheelite occurs in both stratiform lenses and crosscutting veinlets. Signal mine, level 707.

d - Same skarnoid with a metric fold showing a phlogopite-rich layer. Phlogopite yields a 40Ar/39Ar age of 285.3 Ma.

e - Facies of the skarn with disseminated sulfides. Visean formation near Kaolin granite $\mathrm{f}$ - Greisen veins and stockwork. This muscovite-quartz stockwork is a continuation of the W1 north vein within Mine granite.

$\mathrm{g}$ - Pyrrhotite vein (about 0.8 meter thick) with pyrrhotite-arsenopyrite veinlets at footwall and hanging wall. Signal vein level 707.

$\mathrm{h}$ - North side of Mispickel granite (main summit) with Visean (right side). The brownish part between granite and Visean outlines the oxidation zone of the pyrrhotite vein crosscutting the Mispickel granite skarn. Two small galleries have been dug here.

i - Silica breccia from the Tighza structure (photo width: $1 \mathrm{~m}$ )

(all photographs by E Marcoux, except photograph a by K. Nerci) 
Figure 4 - Gold content of the W-type gold veins near the Mine granite (gold analyses by ICP; CMT documents)

Infillings of these veins consist of three stages (Fig. 5):

(1) Stage 1 is an early association of $\mathrm{Q}_{1}$ quartz with wolframite (crystals of $1 \mathrm{~mm}$ to $1 \mathrm{~cm}$ ) turning to scheelite that reflects a high-temperature oxidizing environment (Figs. 6a, 6b);

(2) Stage 2 is an intermediate stage with gold, bismuth and tellurides, and few sulfides, mostly Assulfides, coeval with a brittle tectonic event and the $\mathrm{Q}_{2}$ quartz deposition. Stage 2 is the most abundant in the veins. The near-granite zone (W1 north vein) displays an association of early loellingite and gold, with native bismuth, bismuthinite, tetradymite, joséite $\mathrm{B}\left(\mathrm{Bi}_{4} \mathrm{Te}_{2} \mathrm{~S}\right)$, hedleyite $\left(\mathrm{Bi}_{7} \mathrm{Te}_{3}\right)$, followed by later minor arsenopyrite (Nerci, 2006) (Figs. 6c to 6h). These mineralogical associations are consistent with the strong statistical correlation between $\mathrm{Au}$ and $\mathrm{Bi}(0.88)$ and $\mathrm{Au}$ and Te (0.95) found among more than one hundred of vein ore samples (Nerci, 2006). These minerals do not occur in the distal zone of the W1-W1 north vein system (W1 vein) displaying a low grade in gold, and more abundant arsenopyrite and chalcopyrite. The strong association of gold with loellingite, and not with arsenopyrite, explains the low As-Au correlation (0.13). Grain (10 à $200 \mu \mathrm{m})$ of native gold are associated with bismuth and tetradymite. Electronic microprobe analyses of 18 grains show that gold has homogeneous electrum composition ( $84 \% \mathrm{Au}, 16 \% \mathrm{Ag})$, with regular low Bi values averaging $0.4 \%$. No gold was detected in pyrrhotite and arsenopyrite by ICP/MS laser analysis (detection level: 1 ppm).

(3) Stage 3 is the final stage with massive pyrrhotite - chalcopyrite and sphalerite (Figs. 5, 7). This stage is mainly observed in drill-holes intersecting W1 north and W4. It is composed of veinlets and veins of massive pyrrhotite, chalcopyrite, with locally abundant sphalerite. Stage 3 form 
veinlets cutting earlier grey quartz veins enriched in loellingite-bismuth-gold, or appears as a cement of arsenopyrite-loellingite-native bismuth, or wolframite-bearing quartz clasts (Figs. 7e to $7 h)$.

The "Pyrrhotite vein" strikes $\mathrm{N} 150^{\circ}$ and dips $50-60^{\circ} \mathrm{NE}$, with a mean width of $0.8 \mathrm{~m}$. It has been observed in the mine at the 707 and 857 levels and reaches the surface to the south of Signal shaft, where it is marked by strong magnetic anomalies, indicating a vertical extent of at least $580 \mathrm{~m}$ (Fig. 3g). This vein is dominated by pyrrhotite, sphalerite and arsenopyrite (Figs. 7c, 7d). At the 857 mine level, both the footwall and hanging wall are silicified and show abundant clasts of arsenopyrite bearing numerous early corroded minerals (loellingite, native bismuth and bismuthinite, no gold). Sn and W are also present. Tin occurs as small ovoid patches (average of $200 \mu \mathrm{m}$ ) of cassiterite in quartz or sphalerite (Fig. 7c), sometimes with a crown of stannite. Tungsten forms interstitial scheelite among sulfides. This "Pyrrhotite vein" is thus dominantly part of stage 3 paragenesis of $\mathrm{W}$ veins, and includes relicts of stages 1 and 2 as fragments (Figs. 5, 7h). It is interpreted to belong to the Au-W quartz vein system.

Figure 5 - Paragenetic sequences of the main gold-bearing structures. Most prominent features are illustrated in figures 6 and 7

Figure 6 - Mineralogy of Tighza: ore from early stages

a - Pseudomorphic crystal of scheelite $(\mathrm{Sc})$ after ferberite $(\mathrm{Fb})$ within quartz (dark grey). A few relicts of ferberite are still preserved. W1 north Au-W quartz vein (sample NK 82 b).

$\mathrm{b}$ - Ferberite $(\mathrm{Fb})$ and loellingite (Lo) within quartz (dark grey). W1 north $\mathrm{Au}-\mathrm{W}$ quartz vein (sample NK 74). 
c - Gold (yellow) and native bismuth (Bi) infilling a quartz crack. Enlargement of the gold particle shows the close association with bismuth (Bi). Drill core on W1 north Au-W quartz vein (DDH SW1N-3 bis).

$\mathrm{d}$ - Association of gold (yellow, $14 \mu \mathrm{m}$ in size) and native bismuth (Bi) within loellingite (Lo). A small patch of pyrrhotite (grey-brown) is also visible. Quartz-scheelite stockwork in the Mispickel granite.

e - Association of gold (yellow), native bismuth (Bi) and bismuthinite (Bs) within loellingite (Lo). Drill core on W1 north $\mathrm{Au}-\mathrm{W}$ quartz vein (DDH SW1N).

f - Idiomorphic loellingite (Lo) and small patches of gold (circles) within quartz (dark grey). W1 north $\mathrm{Au}-\mathrm{W}$ quartz vein (sample NK 74)

$\mathrm{g}$ - Native bismuth (Bi) with hedleyite $(\mathrm{Hd})$ in quartz (dark grey). Drill core on W1 north Au-W quartz vein (DDH SW1N).

$\mathrm{h}$ - Loellingite (Lo) as relicts within arsenopyrite (Apy). Drill core on W1 north Au-W quartz vein (DDH SW1N)

\section{2 - Quartz-scheelite stockwork}

Quartz-scheelite stockwork corresponds to minor uneconomic occurrences that are developed on the north-eastern edge of the Mispickel granite and within the Mine granite (see Figs. 2, 3b). Three main families of veinlets are distinguished: $\mathrm{N} 170-180^{\circ} \mathrm{E}, \mathrm{N} 110-120^{\circ} \mathrm{E}$ and $\mathrm{N} 70-80^{\circ} \mathrm{E}$. The mineral association is dominated by wolframite in centimetric crystals, often retromorphosing into scheelite, and loellingite-arsenopyrite. This latter association shows numerous inclusions of native bismuth (up to $300 \mu \mathrm{m}$ ), without bismuthinite, at the contact between the two minerals, and locally with native gold $(20 \mu \mathrm{m})$. 


\section{3 - As-Fe-(Au) dissemination in skarn}

Significant gold anomalies (up to $5 \mathrm{~g} / \mathrm{t} \mathrm{Au}$ ) have been reported in two sites: i) to the southeast of the Kaolin granite, in surface rock samples and in drill-core (S II-4, see Fig. 2); and ii) in drillcores located north of "Au-W-type" veins near the Mispickel granite (FNJ 4, Fig. 2). At both sites, these anomalous gold-bearing disseminated sulfides are linked to Visean carbonate layers, up to one metre thick, which have been hydrothermally metasomatised into skarn facies. The concentration of the sulfides in specific layers leads to a stratabound habit, systematically associated with crosscutting sub-coeval veinlets, filled with the same minerals.

Near the Kaolin granite, at the surface, these anomalies extend for more than $1500 \mathrm{~m}$ and are characterized by strong grey silicification (up to $10 \mathrm{~m}$ thick), with minor arsenopyrite-pyrrhotite (Fig. 3e). They are hosted within a skarn dominated by garnetite (grossular), hedenbergite and wollastonite that is locally replaced by F-bearing vesuvianite (up to $2.2 \mathrm{wt} \%$ ), epidote and chlorite. Sulfides, more abundant in drill holes, are fine-grained and disseminated, dominated by pyrrhotite and arsenopyrite coming from the destabilization of early loellingite. Accessory minerals are chalcopyrite, loellingite, native bismuth (abundant at the contact loellingitearsenopyrite), marcasite, primary and secondary pyrite, bismuthinite, sphalerite, and very rare gersdorffite and nickeline (Fig. 7a). Native gold has not been observed. Hydrothermal alteration is dominated by chlorite. Near the Mispickel granite, similar mineralization has been observed in drill-core (FNJ-4) with abundant pyrrhotite, arsenopyrite and pyrite, less bismuth and no loellingite.

In addition, a calc-silicate skarn have been recognized at the contact of Visean limestones with the Mispickel granite (called "skarn of Mispickel granite" on Fig. 2). The mineralogical association shows four successive stages of calc-silicates: 1) abundant green zoned andradite $\left(\mathrm{An}_{59}-\mathrm{Gr}_{38}\right)$ with 
small amounts of tin $\left(0.12 \% \mathrm{SnO}_{2}\right)$, vesuvianite, wollastonite and diopside; 2) hedenbergite, 3$)$ hydrogrossular and 4) a retrograde evolution giving an actinolite, chlorite and epidote assemblage.

This calc-silicate skarn itself is barren, but it is crosscut by a sulfide-rich vein that contained massive pyrrhotite, chalcopyrite and cubanite (Fig. 2, 3h, 7b). These minerals strongly suggest that the vein is of the same type as the "Pyrrhotite vein" and thus belongs to stage 3 of Au-W quartz veins. Pyrrhotite locally shows abundant small inclusions of early loellingite, native bismuth and arsenopyrite, with some gold (equivalent to stage 2 of the veins). Anomalous gold grades were measured in a very small number of samples from the skarn (3 out of more than 200 samples) and reflect the presence of quartz-loellingite-gold bearing-clasts, indicating a tectonic brecciation of the early W-Au quartz veins with the angular clasts having been reworked and cemented by the late pyrrhotite of stage 3 .

The pyrrhotite-arsenopyrite-sphalerite assemblage of this As-Fe-(Au) association is fairly similar to stages 2 and 3 observed in the Au-W quartz veins and could thus represent the end of gold deposition process.

Figure 7 - Mineralogy of Tighza: ore from late stages

a - As-Fe-( $\mathrm{Au})$ dissemination in skarn showing early arsenopyrite crystals (Apy) corroded by pyrrhotite (Po) within quartz. Noticeable gold grades ( $>5 \mathrm{~g} / \mathrm{t})$ have been measured in this facies. South-East of Kaolin granite (drill-core S II 138 m, sample NK 116).

b - Massive pyrrhotite (Po, grey-brown) with chalcopyrite (Cpy) and residual arsenopyrite (Apy). Pyrrhotite-sphalerite-(chalcopyrite) vein crosscutting the Mispickel granite skarn. 
c - Mineralogy of the pyrrhotite vein. Dominant pyrrhotite (Po) and sphalerite (Sp) are accompanied by chalcopyrite exsolutions (Cpy) and rare cassiterite (Cs). Signal mine, level 707, sample NK 109.

d - Mineralogy of the pyrrhotite vein. Pyrrhotite (Po) and sphalerite (Sp) show residual patches of arsenopyrite-loellingite (Apy). Black patches are silicates. Signal mine, level 707, sample NK 109. e - Clast of arsenopyrite-loellingite (Apy) and quartz (black) (stage 2) cemented by later pyrrhotite (Po) and chalcopyrite (Cpy) within a secondary quartz (stage 3). The pyrrhotite - chalcopyrite association is similar to that of pyrrhotite vein (see photo d). Drill-core cutting W4 vein at $93 \mathrm{~m}$ DDH SW4J-2.

f - Clast of arsenopyrite-loellingite (Apy) with bismuth inclusions (Bi) within quartz (black) invaded by later pyrrhotite (Po)-chalcopyrite (Cpy), within quartz (black). The pyrrhotite chalcopyrite association is similar to that of pyrrhotite vein (see photo d). Drill-cores cutting W4 vein at $93 \mathrm{~m}$ (photo e, DDH SW4J-2) and $160 \mathrm{~m}$ (photo f, DDH SW4J-4).

g - Quartz clast with loellingite (Lo) with gold (Au) and bismuth (Bi) inclusions (stage 2) wrapped in pyrrhotite (Po) - chalcopyrite (Cpy) (stage 3). An enlargement of the gold-bismuth patches is shown. Occasional gold grades in rare bulk pyrrhotite-bearing samples is due to such gold-bearing clasts. Drill-core cutting W4 vein at $160 \mathrm{~m}$ (DDH SW4J-4).

$\mathrm{h}$ - Quartz clast with elongated crystals of ferberite $(\mathrm{Fb})$ largely transformed into scheelite $(\mathrm{Sc})$ (stage 1) and residual arsenopyrite (Apy; stage 2), wrapped into pyrrhotite (Po; stage 3). Quartz is very dark grey. Pyrrhotite vein, Signal mine, level 707, sample NK 109. This photograph shows that early oxidized paragenesis of stage 1 can also be present as clast in this vein

\section{4 - Mineral compositions}


Electron microprobe analyses were performed on several minerals (arsenopyrite, loellingite, sphalerite, and pyrrhotite) associated with the various types of $\mathrm{Au}$ mineralization in the Tighza area (Table 1). Scheelite were also analysed (Table 1). These analyses allow to check the similarity of traces elements in mineral from different locations.

Table 1 - Average composition of sulfide minerals. Number of analyses is within brackets. Electron microprobe analyses EPMA-Electron Probe Micro-Analysis) CAMECA SX 50 (BRGMISTO, Orléans, France). Tension acceleration: 20 kV, current: $10 \mathrm{nA}$. Co, Ge, Ag and Ni have not been detected in sphalerite. Sb is under detection limit in arsenopyrite

Arsenopyrite exhibits a wide range of compositions, even at the vein scale (Fig. 8). The arsenopyrite compositions of various ore types widely overlap: 31.53 to 34.26 (average 32.73 at.\% As) in $\mathrm{W} 1$ vein, 33.0 to 36.5 (average 34.95 at. \% As) for $\mathrm{W} 1$ north vein, 33.4 to 37.0 at.\% As for the pyrrhotite vein. In the As-Fe-(Au) disseminations within skarns, stratabound arsenopyrite has a composition (31.5 to 34.6 at.\% As) slightly different from its associated crosscutting arsenopyrite (31.58 to 32.45 at.\% As). Trace elements are more significant. Co is present in low but systematic amounts in $\mathrm{W} 1$ veins (up to $0.89 \mathrm{wt} \% \mathrm{Co}$ in $\mathrm{W} 1$ vein, and up to $1.55 \mathrm{wt} \%$ in $\mathrm{W} 1$ north vein) especially at the surface level, and in the pyrrhotite vein $(0.10$ to $0.20 \mathrm{wt} \% \mathrm{Co})$. Trace elements in arsenopyrite from the $\mathrm{As}-\mathrm{Fe}-(\mathrm{Au})$ disseminations are different: $\mathrm{Co}$ is absent, but $\mathrm{Bi}$ and $\mathrm{Hg}$ are always present in low contents (up to $0.44 \mathrm{wt} \%$ ) in stratabound arsenopyrite. Antimony has not been detected.

Figure 8 - Bivariate plot of the Co versus As content of arsenopyrite (see Table 1). 
Loellingite has a homogeneous composition with constant sulfur content (average 1.65 wt $\% \mathrm{~S}$ ) and occasional $\mathrm{Co}$ and $\mathrm{Ni}$ contents (about $1 \mathrm{wt} \% \mathrm{Co}+\mathrm{Ni})$. As-Fe-( $\mathrm{Au})$ disseminations in the skarn of Kaolin granite are sulfur-poor $(0.5 \mathrm{wt} \% \mathrm{~S})$ with cobalt and nickel-rich loellingite $(4.0 \mathrm{wt} \%$ and 9.6 wt \% respectively). Pyrrhotite has been analyzed in the pyrrhotite vein of the Mispickel granite skarn, the pyrrhotite vein of the mine, the $\mathrm{Au}-\mathrm{W}$ vein and the As-Fe-(Au) dissemination in the skarn of Kaolin granite. The pyrrhotite compositions are very constant, ranging from 38.5 and 40.0 wt $\% \mathrm{~S}$, implying formulas ranging from $\mathrm{Fe}_{6.67} \mathrm{~S}_{8}$ to $\mathrm{Fe}_{7.02} \mathrm{~S}_{8}$. Sphalerite analyses were limited to the pyrrhotite vein and to the W4 vein drill-cores. Compositions are similar at both sites and exhibits a fairly high iron content (5.8 to $12 \mathrm{wt} \% \mathrm{Fe}$, giving 8 to $22.5 \mathrm{wt} \% \mathrm{FeS}$ ), low $\mathrm{Cd}$ content (average $0.28 \mathrm{wt} \%$ ), but no silver. Scheelites from different ore facies (stockwork, skarn, and level $707 \mathrm{~W}$-Mo vein) were also analyzed: $\mathrm{Pb}$ and Mo contents are too low (respectively 0.37 and $0.32 \mathrm{wt} \%$ ) to distinguish different populations of scheelite.

\section{4 - Fluid inclusions}

\section{1 - W-Au system}

The main tungsten and gold-bearing veins were studied for fluid inclusions in quartz $\mathrm{Q}_{1}$ and $\mathrm{Q}_{2}$ (Nerci, 2006, see annex for methodology). All gold and tungsten bearing-quartz exhibits a twophase infilling with an earlier hyaline quartz $\mathrm{Q}_{1}$ and a later saccharoidal quartz $\mathrm{Q}_{2}$. As mentioned above, $\mathrm{Q}_{2}$ derived in part from $\mathrm{Q}_{1}$ by microfracturing but also comprise neo-formed crystals resulting from silica-rich hydrothermal flows. Two types of fluid inclusions have been identified in $\mathrm{Au}-\mathrm{W}$-type veins and within the quartz-scheelite stockworks of the Mine and Mispickel granites: 
i) low-salinity aqua-carbonic inclusions (type IF1); ii) high-salinity inclusions with at least one solid phase (type IF2) (Fig. 9).

The IF1 type corresponds to sparse pseudo-secondary aqua-carbonic inclusions, only obseryed within the $\mathrm{Q}_{1}$ quartz from the $\mathrm{W}-\mathrm{Au}$ quartz veins. IF1 ranges between 5 and $40 \mu \mathrm{m}$, and are frequently three-phased $\left(\mathrm{L}_{\mathrm{H} 2 \mathrm{O}}+\mathrm{L}_{\mathrm{CO} 2}+\mathrm{V}_{\mathrm{CO} 2}\right.$, Fig. 9A). Generally, by visual estimate, IF1 contain $>50 \%$ vol. of aqueous liquid with respect to $\mathrm{CO}_{2}$ phases. Large portions of these inclusions are exploded or decrepitated and present various morphologies (e.g. lobate, dendritic, half ring....). Very few solid are observable within this inclusion type. The hyaline $\mathrm{Q}_{1}$ quartz being well preserved in the W1 north vein, hereafter are presented mean and range values from 15 studied inclusions. Only six accurate $\mathrm{T}_{\mathrm{h}}$ measures were possible yielding a $240^{\circ}-310^{\circ} \mathrm{C}$ range with homogenization in vapor. $\mathrm{Tm}_{\mathrm{CO} 2}$ ranges between $-57.1^{\circ} \mathrm{C}$ and $-56.7^{\circ} \mathrm{C}$, whereas $\mathrm{Th}_{\mathrm{CO} 2}$ ranges between $22.5^{\circ} \mathrm{C}$ and $27.5^{\circ} \mathrm{C}$ in vapor. These temperatures have been reported in the $\mathrm{V}-\mathrm{X}$ projection of Thiéry et al. (1994) for the $\mathrm{CO}_{2}-\mathrm{CH}_{4}$ system: $\mathrm{X}_{\mathrm{CH} 4}$ is about $0.5-3.2 \%$ mol and the molar volume of volatile phase ranges between 143 and $169 \mathrm{~cm}^{3} / \mathrm{mol}$. Raman spectroscopy confirmed the presence of $\mathrm{CH}_{4}$. Although $\mathrm{Tm}_{i c e}$ is difficult to determine for each inclusion, we obtain a mean value of $-3.7^{\circ} \mathrm{C}$ on three inclusions. Assuming a $\mathrm{CO}_{2}$ contribution of $-1.48^{\circ} \mathrm{C}$ (ice melting temperature in the $\mathrm{H}_{2} \mathrm{O}-\mathrm{CO}_{2}$ system), the $\mathrm{NaCl}$ contribution is estimated around $-2.22^{\circ} \mathrm{C}$. This yields a salinity of 3.7 wt $\% \mathrm{NaCl}$ from $\mathrm{H}_{2} \mathrm{O}-\mathrm{NaCl}$ equiv. system equation (Bodnar, 1993). Molar fractions and global density have been estimated with the method developed by Ramboz et al. (1985): compositions are homogenous with $1 \mathrm{~mol} \% \mathrm{NaCl}, 17-19 \mathrm{~mol} \% \mathrm{CO}_{2}, 80-82 \mathrm{~mol} \%$ $\mathrm{H}_{2} \mathrm{O}$ and traces of $\mathrm{CH}_{4}$, for a global density of $0.53 \pm 0.1 \mathrm{~g} / \mathrm{cm}^{3}$. Finally, using isochores from the equation of Bowers and Helgeson (1986) for the $\mathrm{CO}_{2}-\mathrm{H}_{2} \mathrm{O}-\mathrm{NaCl}$ system, the trapping temperature and pressure were evaluated in ranges of $400-600^{\circ} \mathrm{C}$ and $640-1490$ bars. Because the $\mathrm{Q}_{1}$ quartz hosts the W-bearing minerals, the IF1 type, pseudo-secondary inclusions, are considered to be 
associated with the early wolframite-scheelite stage. On the scale of the district, the IF1 inclusions are characterized by deformation, re-equilibration and explosions, coeval with a cataclasis of hyaline quartz $\mathrm{Q}_{1}$, and appearance of “dry” microcracks, without fluid inclusion.

Figure 9 - Fluid inclusions types and isochores obtained for the second generation of fluid inclusions (IF2) in the $\mathrm{Au}-\mathrm{W}(\mathrm{A}, \mathrm{B}, \mathrm{C}$ and $\mathrm{D})$ and for the $\mathrm{Pb}-\mathrm{Ag}$ mineralizing systems (isochores only). A: typical biphased inclusion with liquid and vapor phases; B: fluid inclusion planes within Q1; C and D: high-salinity inclusions with hyalite cube $(C)$ and hyalite cubes and dark inclusion of chalcopyrite . All isochores are constructed in the $\mathrm{H} 2 \mathrm{O}-\mathrm{NaCl}$ system. Lithostatic and hydrostatic gradient were constructed using a reasonable geothermal gradient of $50^{\circ} \mathrm{C}$ per $\mathrm{km}$ with mean densities of 2.5 and 1 for rocks and water-rich fluids respectively. For IF2 fluids trapping PT conditions are bracketed between $200 \mathrm{Mpa} / 400^{\circ} \mathrm{C}$ in lithostatic regime and $42 \mathrm{Mpa} / 267^{\circ} \mathrm{C}$ in hydrostatic regime. This very large range is discussed in further section in text. For mineralizing brines of the $\mathrm{Pb}-\mathrm{Ag}$ systems, textures diagnostic of hydrostatic conditions favor trapping conditions at $27 \mathrm{Mpa} / 242^{\circ} \mathrm{C}$

The IF2 type is found: i) within $\mathrm{Q}_{1}$ along numerous fluid inclusion planes (12 studied IF2, Fig. 9B); ii) as primary inclusions within $\mathrm{Q}_{2}$ neo-grains (Fig. 9C); iii) within fractured quartz of quartzscheelite stockworks (20 studied IF2, Fig. 9D). They clearly post-date IF1. IF2 are multiphased inclusions with liquid and vapor phases (max $15 \%$ vol. ratio) still in the presence of solids ( $\max$ $30 \%$ vol. ratio). Halite crystals are easily recognizable by their cubic geometry and refringence. Raman spectroscopy allows us to identify refringent solids such as carbonates (calcite), micas, and chalcopyrite (Fig. 9D), $\mathrm{Ts}_{\mathrm{NaCl}}$ (dissolution temperature) ranges between $220.5^{\circ} \mathrm{C}$ and $282.2^{\circ} \mathrm{C}$. These dissolution temperatures yield salinity range of 33.65-36.80 wt $\% \mathrm{NaCl}$ equiv. in the $\mathrm{H}_{2} \mathrm{O}$ - 
$\mathrm{NaCl}$ system (Bodnar and Vityk, 1994). Homogenization temperatures (gas bubble resorption) give a $257-284^{\circ} \mathrm{C}$ range with $\mathrm{T}_{\mathrm{h}}>\mathrm{Ts}_{\mathrm{NaCl}}$. Because $\mathrm{Q}_{2}$ quartz is associated with the gold-bearing stage 2 (see above), it is likely that these IF2 fluids were rich in Au-Te-Bi-Cu (and possibly $\mathrm{Si}$ ).

\section{2 - Pb-Ag-Zn system}

In order to facilitate a comparison with the W-Au deposition system, a limited study was carried out on fluid inclusions within calcite associated with the $\mathrm{Pb}-\mathrm{Ag}-\mathrm{Zn}$ mineralization in the Sidi Ahmed vein (15 IF measurements). The banded and geodic textures of quartz and carbonates suggest a shallow deposition process under hydrostatic fluid pressures. Most of the inclusions are liquid-dominated and show a gas and a solid phase (carbonate or salt cube). Two families of fluid could be distinguished based on Te at $-50^{\circ} \mathrm{C}$ and $-70^{\circ} \mathrm{C}$ (secondary inclusions). The first one reflect $\mathrm{Na}-\mathrm{Ca}$ enriched brines whereas the complex melting and freezing behavior (irreversible) of the second suggest presence complex fluid system, implying organic compounds for instance. $\mathrm{Ts}_{\mathrm{NaCl}}$ determined for the first type presenting salt cubes, yield salinities around $31 \mathrm{wt} \% \mathrm{NaCl}$ equiv. in the $\mathrm{H}_{2} \mathrm{O}-\mathrm{NaCl}$ system (Bodnar and Vityk, 1994). Homogenization temperatures are rather dispersed between $165^{\circ}$ and $217^{\circ} \mathrm{C}$ for the primary generation and around $180^{\circ} \mathrm{C}$ for the second. Both homogenize in liquid phase.

\section{3 - Trapping conditions}

Several isochores have been traced using the Loner 32 program (Bakker, 2003) in the $\mathrm{H}_{2} \mathrm{O}-\mathrm{NaCl}$ system (Knight and Bodnar, 1989; Bodnar, 1993; Bodnar and Vityk, 1994) (Fig. 9E). To estimate a true trapping temperature, a pressure correction was applied to the homogenization temperatures based on a mean thermobarometric gradient of $50^{\circ} \mathrm{C}$ and $25 \mathrm{Mpa}$ per $\mathrm{km}$ for the district when 
granitic magmatism and hydrothermal events occurred. For the W-Au system, IF2 type fluids were trapped at maximum conditions near $200 \mathrm{Mpa}$ and $400^{\circ} \mathrm{C}$ (Fig. 9E: intersection between the lithostatic gradient and the isochore calculated from the maximum $\mathrm{Th}$ ) and minimum conditions near $40 \mathrm{Mpa}$ and $265^{\circ} \mathrm{C}$. In the $\mathrm{Pb}-\mathrm{Ag}-\mathrm{Zn}$ system, accounting for veins textures which are diagnostic of large permeabilities and hydrostatic conditions, minimal trapping conditions are estimated around $30 \mathrm{Mpa}$ and $250^{\circ} \mathrm{C}$ (Fig. 9E).

\section{5 - Isotopic geochemistry}

${ }^{40} \mathrm{Ar} /{ }^{39} \mathrm{Ar}$ dating was done to better constrain the age of magmatic and hydrothermal events. $\mathrm{Pb}$ isotope analyses were performed in order to constrain the origin and relationship of the various types of ores, and the possible link between $\mathrm{Pb}-\mathrm{Ag}-\mathrm{Zn}$ veins and granites. Similarly, $\mathrm{Sm}-\mathrm{Nd}$ and $\mathrm{Sr}$ isotopes of scheelite from various ore types were performed to constraint the relationship of the different ore systems.

\section{$5.1-{ }^{40} \mathrm{Ar}{ }^{39} \mathrm{Ar}$}

Two biotites/phlogopites from the Mine granite and W1 vein and two muscovites were dated using $\mathrm{a}^{40} \mathrm{Ar}^{39}{ }^{39} \mathrm{Ar}$ laser probe (see annexes for methodology). The Mine granite biotite (NK 211) yielded an age of $286.0 \pm 0.4 \mathrm{Ma}$, whereas the W-skarn (NK 222) and W-Mo vein (NK 220) from level 707 in Signal mine dated using muscovite yielded 285.3 $\pm 0.5 \mathrm{Ma}$ and 285.6 $\pm 0.5 \mathrm{Ma}$ respectively (all uncertainties: $1 \sigma$ level) (Table 2 and Fig. 10).

These new data are consistent with and provide further constraints to the previous K-Ar dating by Cheilletz (1984) who dated the Mine granite at 287.9 \pm 5.1 Ma and 291.1 \pm 15.2 Ma, the W-skarn 
at $285.3 \pm 3.0 \mathrm{Ma}$ and $284.1 \pm 4.2 \mathrm{Ma}$, and the $\mathrm{W}$-vein at $288.4 \pm 3.1 \mathrm{Ma}$. The W-Au mineralization is therefore strictly coeval with the cooling of the Permian-aged Mine granite.

It is noteworthy that a fresh phlogopite sampled at the surface on the W1 north vein (NK 313) gave an age of $291.8 \pm 0.3 \mathrm{Ma}$, slightly older than the above ages, older than the $\mathrm{K}$-Ar age obtained on the W1 by Cheilletz (1984) at $285.0 \pm 3.8 \mathrm{Ma}$, and also older that the Mine granite. This apparent discrepancy will be discussed later (see Discussion). Dating of associated muscovite (NK 312) did not yield a viable spectrum.

Table $2-{ }^{40} \mathrm{Ar} /{ }^{39} \mathrm{Ar}$ analytical data. ${ }^{40} \mathrm{Ar}_{\mathrm{atm}}=$ atmospheric ${ }^{40} \mathrm{Ar} .{ }^{40} \mathrm{Ar} *=$ radiogenic ${ }^{40} \mathrm{Ar} . \mathrm{Ca}=$ produced by $\mathrm{Ca}$-neutron interferences. $\mathrm{K}=$ produced by $\mathrm{K}$-neutron interferences. Age $(\mathrm{Ma})=$ the date is calculated using the decay constants recommended by Steiger and Jäger (1977). The errors are at the $1 \sigma$ level and do not include the error in the value of the $\mathrm{J}$ parameter. Correction factors for interfering isotopes produced by neutron irradiation in the McMaster reactor were $\left({ }^{39} \mathrm{Ar} /{ }^{37} \mathrm{Ar}\right) \mathrm{Ca}=7.06 \times 10^{-4},\left({ }^{36} \mathrm{Ar} /{ }^{37} \mathrm{Ar}\right) \mathrm{Ca}=2.79 \times 10^{-4},\left({ }^{40} \mathrm{Ar} /{ }^{39} \mathrm{Ar}\right) \mathrm{K}=2.97 \times 10^{-2}$

Figure $10-{ }^{39} \mathrm{Ar}-{ }^{40} \mathrm{Ar}$ age spectra. The age error bars for each temperature steps are at the $1 \sigma$ level and do not include errors in the J-values. The errors in the J-values are included in the plateau age calculations

\section{2 - Lead}

Twenty-one sulfide samples, mainly galena, were collected from the different mineralized structures, and two K-feldspars from the Mine and the Mispickel granites have been analyzed. These data are complemented by $\mathrm{Pb}$ isotope data from the Signal $\mathrm{Pb}-\mathrm{Ag}-\mathrm{Zn}$ vein (Watanabe, 
2002). The lead isotope data are widely dispersed, ranging from 18.25 to $18.90\left({ }^{206} \mathrm{~Pb} /{ }^{204} \mathrm{~Pb}\right.$ ratio), suggesting the interaction of several sources (Table 3 and Fig. 11)

The ${ }^{206} \mathrm{~Pb} /{ }^{204} \mathrm{~Pb}$ isotope ratios of galena from gold-bearing veins (W-Au quartz veins) define a fairly wide range from 18.29 to 18.42 and are independent of vein location or proximity to the Mine granite. The isotopic compositions of the pyrrhotite vein and of the Mispickel pyrrhotite deposit overlap the least radiogenic ${ }^{206} \mathrm{~Pb} /{ }^{204} \mathrm{~Pb}$ of the $\mathrm{W}$ veins, although $\mathrm{As}-\mathrm{Fe}-(\mathrm{Au})$ skarn compositions fall within field for the W-Au quartz veins (18.299 to 18.343 for ${ }^{206} \mathrm{~Pb} /{ }^{204} \mathrm{~Pb}$ ratio).

There is no distinction between northern (Mispickel granite) and southern (Kaolin granite) skarns. Nevertheless, the $\mathrm{Pb}$ isotope compositions of sulfides (pyrrhotite+sphalerite) of the W-skarn associated with the Mine granite yield more highly radiogenic and dispersed ratios (18.27 to 18.90 ${ }^{206} \mathrm{~Pb} /{ }^{204} \mathrm{~Pb}$ ratios) and are reminiscent of sulfides associated with black shales or limestones. The K-feldspar compositions are close to $18.30\left({ }^{206} \mathrm{~Pb} /{ }^{204} \mathrm{~Pb}\right.$ ratio $)$ and are similar to values of Hercynian granites (Marcoux, 1987). Thus these granites are not likely a major source for the WAu mineralization.

The lead isotopic compositions of the $\mathrm{Pb}-\mathrm{Ag}-\mathrm{Zn}$ major veins are clustered in a relatively narrow field $\left(18.265 \pm 0.035\right.$ for ${ }^{206} \mathrm{~Pb} /{ }^{204} \mathrm{~Pb}$ ratio $)$ and overlap the lowest ${ }^{206} \mathrm{~Pb} /{ }^{204} \mathrm{~Pb}$ ratios of the $\mathrm{W}-\mathrm{Au}$ mineralization (Fig. 11). The new analyses performed for this study are identical $( \pm 3 \sigma)$ to those published by Watanabe (2002).

The results show what can be considered as a short fractionation line with Sidi Ahmed $\mathrm{Pb}-\mathrm{Ag}-\mathrm{Zn}$ veins forming the least radiogenic end-member at $18.232\left({ }^{206} \mathrm{~Pb} /{ }^{204} \mathrm{~Pb}\right)$ and $15.68\left({ }^{207} \mathrm{~Pb} /{ }^{204} \mathrm{~Pb}\right)$. Although these veins are the youngest in the district, they exhibit the least radiogenic ratios. 
As a whole, the lead isotopic compositions of Tighza district are characterized by high ${ }^{207} \mathrm{~Pb} /{ }^{204} \mathrm{~Pb}$ ratios, indicating a source in the upper continental crust (Stacey and Kramers, 1975; Doe and Zartman, 1979).

Figure 11 - Pb-Pb diagram of the various type of mineralization. Stacey-Kramers (1975) growth curve and Doe and Zartman (1979) orogen curve are mentioned (see Table 3)

Table 3 - Lead isotope compositions of Tighza ores. Samples analyzedAg-Zn veins (galenas) and K-feldspars. Analyses performed by J.J. Peucat (University of Rennes France), except (1) by Watanabe (2002). Analytical uncertainties see annexes

\section{3 - Sr and Sm/Nd}

$\mathrm{Sr}$ and $\mathrm{Nd}$ isotope data for scheelite and whole-rock samples from the Tighza area are presented in Table 4 and Figure 12. The $\mathrm{Sr}$ isotope compositions of the scheelites are considered initial ratios due to the very Sr rich $(>1000 \mathrm{ppm})$ and $\mathrm{Rb}$-poor $(<5 \mathrm{ppm})$ nature of the mineral. The analyses of the scheelites yield $\mathrm{Sr}$ isotope compositions that vary from 0.7089 to 0.7136 . These results are, for the most part, less radiogenic and more variable than the $\mathrm{Sr}$ isotope data obtained from siderite of $\mathrm{Pb}-\mathrm{Ag}$ veins analyses by Castorina and Masi (2000). The greater variability obtained in this study likely reflects the more widespread sampling of this study and the less radiogenic Sr isotope ratios are evidence of the contribution of a less radiogenic fluid component. The variation in the scheelite Sr isotope ratios at Tighza is also independent of sample localities in the granite and the overall vein structures/types. For example, two different, but closely spaced gold veins (W4 and W5) 
yield different $\mathrm{Sr}$ isotope ratios of 0.710 and 0.713 , respectively. Although the Tighza scheelites partially overlap the initial Sr isotope compositions of the Mine Granite, Mispickel granite and granites from Castorina and Masi (2000), the granites are generally exhibit the least radiogenic (most primitive) compositions. Nd isotope analyses of the granitic and rhyolitic rocks yield typical crustal Nd contents $(21-31 \mathrm{ppm})$ and ${ }^{147} \mathrm{Sm} /{ }^{144} \mathrm{Nd}$ ratios $(0.096-0.122)$. The scheelites are much richer in $\mathrm{Nd}(215-636 \mathrm{ppm})$ and have near chondritic ${ }^{147} \mathrm{Sm} /{ }^{144} \mathrm{Nd}$ ratios $(0.186-0.218)$. The initial $\varepsilon \mathrm{Nd}$ values (at $300 \mathrm{Ma}$ ) of the granites and rhyolite range from -3.6 to -6.6 and are more radiogenic (and thus more primitive) than the range of initial $\varepsilon N d$ values $(-2.4$ to -8.2$)$ found in the scheelites.

Table 4 - Sr and Nd results (analyses: R. Stevenson, GEOTOP/UQAM Montréal, Canada)

Figure 11 - Plots of $\varepsilon N d$ versus 87/86Sr (a) and 87/86Sr versus Sr concentration (b) for lithologies and mineral deposits of the Tighza district. Field for Cambrian basement (sedimentary rocks) from Schaltegger et al. (1994), and additional granite and siderite data from Castorina and Masi (2000). The $\mathrm{Sr}$ and $\mathrm{Nd}$ isotope data argue for an interaction between basement sedimentary fluids and primitive granite-derived fluids

\section{6 - Genesis of the Tighza polymetallic district}

Until now, each of the different styles of mineralization has been interpreted separately (Cheilletz and Giuliani, 1988; Castorina and Masi, 2000, Watanabe, 2002). The above data allows us to propose an integrated model for the emplacement of the successive mineralizing events in the Tighza area. 


\section{1 - Plutonic events and igneous metallogeny}

The $286.0 \pm 0.4 \mathrm{Ma}{ }^{40} \mathrm{Ar}-{ }^{39} \mathrm{Ar}$ age obtained on biotite from the Mine granite confirms the previous published ages (Cheilletz, 1984). The emplacement of the granitic stocks is strongly controlled by wrench faulting. Particularly, the Mine granite, which corresponds to an apex of a larger underlying plutonic complex (Eldursi et al., 2009), is emplaced along a dilational horsetail termination of the dextral W-veins system, during the D2 tectonic event. Such setting indicates that the structural level corresponds to the brittle/ductile transition in high geothermal regime.

The geochemistry of the three Permian granitic stocks is relatively homogeneous (Table 1). The degree of fractionation with respect to the degree of oxidation of the parent magmas is shown on the $\mathrm{Rb} / \mathrm{Sr}$ vs. $\mathrm{Fe}_{2} \mathrm{O}_{3} / \mathrm{FeO}$ plot for the three main stocks and is clearly located on the boundary of the IRGD domain with the W domain (Fig. 13). The parent granitic magma is moderately oxidized and fractionated close to the clan of the "Intrusion-related gold deposits" associated with a W-Mo metal assemblage, as defined by Blevin et al. (1996) and Blevin (2004). Such a moderate state of oxidation and fractionation may be interpreted as a mantle origin of the magma partly reduced by the abundant crustal organic matter within the Paleozoic rocks.

Figure 12 - Oxidation and fractionation state of the three main Permian stocks of the Tighza area (black square: Mine granite; white square: Kaolin granite; gray square: Mispickel granite). Oxidation and fractionation of magmas associated with different dominant metal assemblage are schematically represented. Area limited by red dash line corresponds to the magma composition from the Intrusion-related Gold Deposits (IRGD) (from Blevin et al., 1996, and Blevin, 2004)

\section{2 - W-Au events}


Three paragenetic events can be distinguished among the Tighza W-Au occurrences.

Stage 1 consists of an early association of wolframite followed by scheelite, represented by early stratabound lenses of skarns and $\mathrm{W}$ (not yet $\mathrm{Au}$ ) quartz veins; the early $\mathrm{W}$-only association reflects clear sub-magmatic conditions typical of a reduced skarn environment (Einaudi et al., 1981). Initial temperatures of the hydrothermal system reach $580^{\circ} \mathrm{C}$ and $1.8 \mathrm{~Kb}$ during early skarn mineralization and $400^{\circ}$ to $450^{\circ} \mathrm{C}$ and $100 \mathrm{MPa}$ for vein-style deposits (Cheilletz and Isnard, 1985). The IF1 $\mathrm{CO}_{2}$-rich fluids are interpreted to be coeval with stage 1 (Fig. 9). These $\mathrm{CO}_{2}$-rich fluids are occluded as primary or pseudo-secondary inclusions within $Q_{1}$ quartz which is coeval with $\mathrm{W}$ minerals. Therefore, the spatial link of $\mathrm{W}$ mineralization with the Mine granite (i.e. the inner $\mathrm{W}$ circle) strongly suggests that $\mathrm{CO}_{2}$ was exsolved from felsic melts as demonstrated in numerous modern systems (Etiope and Martinelli, 2002). Exsolution of early $\mathrm{CO}_{2}$-rich fluids from felsic melts is well established as $\mathrm{CO}_{2}$ is much less soluble than $\mathrm{H}_{2} \mathrm{O}$ in melts (e.g. Fogel and Rutherford, 1990).

Stage 2 consists of an intermediary gold-bearing stage with native gold, bismuth and tellurides, and a few sulfides, mostly loellingite and arsenopyrite; W-rich quartz veins reflect the transition from a pervasive metasomatic process with a limited permeability to circulation in connected fractures, therefore implying a transition from an aseismic to a seismic environment. The zoning in the W1 vein from the Au-rich to the As-rich zones could be the result of both temperature and fugacity, where the center of the hydrothermal system is located on the Mine granite with high temperature, and $\mathrm{fS}_{2}$ increase outward in the shale-hosted host-rocks. The temperature of deposition of this gold stage can be deduced from the paragenetic association, specifically the presence of rare Bi-Te minerals. According to Afifi et al. (1988) and Dimitrova and Kerestedjian (2006), the bismuth+hedleyite association exists only below $266^{\circ} \mathrm{C}$. A minimum temperature for 
presence of pyrrhotite and bismuthinite is $235^{\circ} \mathrm{C}$ (Afifi et al., 1988). With a decreasing temperature, loellingite development and disappearance of bismuthinite correspond to a decrease in the $\mathrm{S}_{2}$ fugacity (Fig. 14). The presence of Te minerals is probably an indication of the condensation of evolving magmatic fluids as Te has a low solubility in this type of fluids (Cook and McPhail, 2001; Tombros et al., 2010). The presence of nickeline could reflect enhanced $\mathrm{Ni}$ mobility in sulfur poor systems under approximately neutral to acidic conditions (Bermanec et al., 2000). These results confirm the measured $T_{h}$ values for fluid inclusions (IF2), between 257 to $284^{\circ} \mathrm{C}$. A pressure of $20 \mathrm{MPa}$ for a hypersaline fluid can be determined from the $\mathrm{NaCl}$ fluid stability diagram (Liebscher, 2007). As mentioned above the trapping pressure for the IF2 inclusions is difficult to pinpoint (Fig. 9E), homogenization being achieved by bubble disappearance rather than by halite dissolution $\left(\mathrm{T}_{\mathrm{h}}>\mathrm{Ts}_{\mathrm{Nacl}}\right)$. However, a low trapping pressure for IF2 fluids is also consistent with the small differences in temperatures determined from mineral. This would imply therefore a large decrease in pressure from the previous W stage. Such decrease may have been facilitated by a transition from lithostatic to hydrostatic pressure. Indirect spatial and temporal constraints on IF2 trapping conditions will be implied and discussed in the next section.

Stage 3 consists of massive pyrrhotite - chalcopyrite and sphalerite, and accessory Sn minerals (cassiterite, stannite). The third stage appears after a fracturing event, and either cements quartzgold-sulfides clasts of the previous stages (W veins), or more often forms independent deposits (the Pyrrhotite vein and sulfide vein that crosscut the skarn of the Mispickel granite). Late $\mathrm{Zn}-\mathrm{Cu}$ (Sn) stage 3 deposition of massive pyrrhotite - chalcopyrite - sphalerite is characterized by lower sulfur fugacity $\left(\log \mathrm{fS}_{2}<-11\right)$ as indicated by the composition of the sphalerite $(8-22.5$ at.\% $\mathrm{Fe})$ coeval with pyrrhotite crystallization. 
The Tighza W-Au system is pyrite-depleted, pyrrhotite-rich, with numerous As-sulfides that, when combined with the presence of $\mathrm{Bi}-\mathrm{Te}$ minerals and the low homogenization temperature, demonstrate that the system as a whole is sulfur-deficient.

Figure 13 - Evolution of the conditions of deposition in a $\mathrm{fS}_{2}-\mathrm{t}^{\circ} \mathrm{C}$ diagram (grey arrow), established from fluid inclusion and paragenetic studies. Scheelite-skarn temperature formation $\left(580^{\circ} \mathrm{C}\right.$, Cheilletz and Isnard, 1985) has been considered as the starting conditions. Stage 1 conditions are deduced from $\mathrm{CO}_{2}$-rich IF1 fluid inclusion studies, paragenetic assemblages and As at.\% of arsenopyrite. Stage 2 conditions $\left(265-400^{\circ} \mathrm{C}\right)$ take into account paragenetic equilibrium observed and IF2 fluid inclusions. Stage $3\left(<265^{\circ} \mathrm{C}\right)$ drastical change in $\mathrm{fS}_{2}$ is a result of sphalerite iron content. Deposition conditions of late $\mathrm{Pb}-\mathrm{Zn}$ veins are not figured. Equilibrium curves and stability fields are from Kretschmar and Scott, 1976, Vaughan and Craig, 1997, and Barnes, 1997

The spatial setting of these three stages defines a perigranitic zoning model, with an inner W circle, a middle circle up to $400 \mathrm{~m}$ with $\mathrm{Bi}, \mathrm{Te}, \mathrm{Au}$ and As. From the granite border outward, loellingite is replaced by arsenopyrite and gold grade shows a clear decrease from 21 ppm within the $200 \mathrm{~m}$ closest to the granite to $5 \mathrm{ppm}$ over the next $500 \mathrm{~m}$ (see Fig. 4). The most economic gold target, the Au-W quartz veins, displays these three paragenetic stages with stages 1 and 2 being the most representative.

\section{3 - Pb-Ag-Zn events}

$\mathrm{Pb}-\mathrm{Ag}-\mathrm{Zn}$ veins record a different hydrothermal event compared to that of the $\mathrm{W}-\mathrm{Au}$ quartz veins. The structural style is clearly associated with the regional left-lateral wrenching D3 event. Fluid inclusion microthermometry suggests a minimum temperature around $230^{\circ} \mathrm{C}$ in the Sidi Ahmed 
$\mathrm{Pb}-\mathrm{Ag}-\mathrm{Zn}$ vein and geodic textures and collapse breccias suggest emplacement at a shallow level in a low hydrostatic pressures environment.

\section{4 - Fluids and metals sources}

The radiogenic isotope studies $(\mathrm{Pb}, \mathrm{Sr}, \mathrm{Nd})$ indicate that there is a strong link between the different mineralization stages and magmatic/crustal fluids. The initial $\mathrm{Sr}$ and $\mathrm{Nd}$ isotope ratios associated with the early $\mathrm{W}$ mineralization overlap the field of isotopic compositions from the Cambrian shales/schists of the Moroccan basement (Schaltegger et al., 1994), and extend towards the primitive $\mathrm{Sr}$ and $\mathrm{Nd}$ isotope ratios of defined by the Hercynian granites. This suggests a convective cell involving fluids from the granites (Mine and Mispikel) and fluids from the enclosing rocks (Cambrian basement) led to the deposition of the early W (and gold) mineralization. This model can explain the presence of a more crustal fluid in the formation of the siderites (Castorina and Masi, 2000) and is consistent with the model of hydrothermal W deposits of Heinrich (2007). This strongly suggests that the fluids responsible for the formation of Tighza W-Au mineralization were a mixture of fluids remobilized from the underlying Cambrian basement and fluids derived from juvenile granitic magmas.

The compositional field of the different ore types can be interpreted representing mixing between a less radiogenic component (the local granite intrusions) and a more radiogenic component often found in black shales and carbonated rocks.

A plot of the lead isotope data on usual $\mathrm{Pb}$ diagram suggests that the different mineralization events were linked to two different hydrothermal systems (Fig. 11). The earlier mainly advective system was associated with the vein type W-Au mineralization, while the second convective system was associated with the later $\mathrm{Pb}-\mathrm{Ag}-\mathrm{Zn}$ veins mineralization. Both advective and 
convective systems appear to share a common magmatic component as defined by the K-feldspars from the local granites, but diverge at higher ${ }^{206} \mathrm{~Pb} /{ }^{207} \mathrm{~Pb}$ ratios towards the values defined by the W-skarnoids (Fig. 15).

\section{7 - Discussion}

\section{1 - An integrated structural-hydrothermal model}

With the exception of the Sb-Ba veins that were not studied in this paper, the Tighza polymetallic district appears to be the result of the superposition of two major metallogenic events (Fig. 15):

1) An early $\mathrm{W}-\mathrm{Au}-(\mathrm{Cu}-\mathrm{Zn}-\mathrm{Mo})$ mineralization event related to a late-Hercynian (286 Ma) magmatic event and;

2) A late event with $\mathrm{Pb}-\mathrm{Ag}-\mathrm{Zn}$ veins that are independent of, and crosscut granite and previous W-Au mineralization.

The location of the gold system is restricted to the proximity of three small granite apexes (Mispickel, Mine and Kaolin granites). The termination of the W1 north vein at the contact of the Mine granite and its strike extension along a hydrothermalized faulted corridor with greisen alteration (see Fig. 2 and 3f) strongly suggests that it predates granite emplacement (Fig. 15A). This interpretation is supported by the younger age of the granite (286 Ma), relative to the phlogopite of W1 north vein $(291.8 \pm 0.3 \mathrm{Ma}$, Table 2 and Fig. 10). There is clear evidence that the $\mathrm{W}$-structures were active during the three stages of the $\mathrm{W}$-Au mineralizing event (e.g. the fracturing and brecciation between the different stages). This occurred during the D2 right-lateral transtensive tectonic event. Furthermore, structural patterns and chronological constraints strongly 
argue for emplacement of the Mine granite stock within the transtensional zone constituted by the horsetail termination (W1 north, WO3, W4, W5, W6, see Fig. 2) of the W-structures during the D2 right-lateral wrenching (Fig 15B). The structural context indicates that this $\mathrm{W}-\mathrm{Au}$ was related to a compressive D2 stress pattern, with the main principal stress oriented NW-SE. Therefore, the intrusive process that generate an Herzian concentric stress pattern with a vertical main principal stress during granite emplacement was already ended.

Movements associated with the formation of the "greisen" corridor resulted in the crushing of $\mathrm{Q}_{1}$ wolframite-quartz (stage I), generating a more saccharoidal, porous quartz $\left(\mathrm{Q}_{2}\right)$, that was more favorable to a diffusion of gold and sulfides-bearing fluids (stage 2). This supports the hypothesis of the release of magmatic gold-bearing fluids during the late-crystallization stage of the magma in pre-existing E-W corridors, including the major W1 and W1 north veins, and their WO3, W4 and W5 associated structures (Fig. 15B). These corridors were thus reactivated and invaded by fluids as long as there was magmatic activity in the district, i.e. at least for $5 \mathrm{Ma}$ (291.8 Ma to $285 \mathrm{Ma})$. A strong mineralogical and geochemical zoning is apparent around the pluton, with a decreasing gold content and an increasing As association (Fig. 4, 15C). Such zoning was a result of a thermal gradient during gold-tungsten deposition.

The variation in the depth of the mineralizing system between stage I (W) and 2 (Au bearing) is difficult to estimate because IF2 fluid inclusions do not yield unequivocal minimum trapping pressures. The numerous exploded inclusions observed among the IF1 inclusions argue for rapid depressurization of the system. However, the concentric geochemical and mineralogical zonation between the $\mathrm{W}$ and $\mathrm{Au}$ stages around the Mine granite, the strong genetic relationships between granites and $\mathrm{W}-\mathrm{Au}$ event, the lack of a telescoping intrusion and the short time span for the emplacement of granitic stocks of similar composition in general (no more than 100000 years, e.g. 
Petford et al., 2000) strongly argue for deposition of W and Au stage (and probably the pyrrhotite bearing stage 3 too) at approximately the same depth. Explosion and decrepitation of IF1 inclusions might be then result either from late large-scale rapid uplift after the $\mathrm{W}$-Au mineralizing event (e.g. during the $\mathrm{Pb}-\mathrm{Zn}-\mathrm{Ag}$ event), or from rapid decompression caused by severe D2 incremental fracturing along the $\mathrm{W}$-structures between the $\mathrm{W}$ and the $\mathrm{Au}$ stages. This last hypothesis is favored because it fits well with the strike slip movements observed in $\mathrm{Pb}-\mathrm{Zn}-\mathrm{Ag}$ veins and the absence of exploded or decrepitation features in the IF2 inclusions. This would suggest a transition from lithostatic to hydrostatic fluid pressure between W stage and Au stage. Thereafter, if $\mathrm{CO}_{2}$-rich fluids (IF1) were trapped around $1.5 \mathrm{kbar}$ during the lithostatic regime (i.e. depth of $5.5 \mathrm{~km}$, Cheilletz and Isnard, 1985), the minimum trapping pressure for saline $\mathrm{H}_{2} \mathrm{O}$-rich fluids (IF2) would be the hydrostatic value at this depth, i.e. around 550 bars. Such transition from lithostatic to hydrostatic fluid pressure regime has been frequently documented in many nonporphyry intrusion-related ore deposits (e.g. the skarn-related iron deposits of Vegas Peladas; Pons and Franchini, 2009).

Figure 14 - 3D and polyphased genetic model for Tighza

Stage 1 - Incipient right-lateral transtensive D2 event, responsible for the formation of premagmatic "W" structures. Primary hydrothermal fluids (dash line arrows) have likely percolated along those faults and are responsible for phlogopite deposition around 291 Ma. Mineral phases associated with phlogopite have not been recognized in this study.

Stage 2 - Global Au-W stage (ca $285 \mathrm{Ma}$ ). Veins emplaced under pressures of $1.5 \mathrm{kbar}$, i.e. at 5-6 $\mathrm{km}$ depth. On the right, upper drawing shows emplacement detail during early W-stage, subcoeval of intrusion, lower drawing detail during cooling, coeval of stage 2 (gold deposition) and stage 3 (pyrrhotite deposition). 
Stage 3 - Pb-Zn-Ag stage following uplift at ca 265 Ma. This stage occurred at least after tonalite intrusion, under 200 bars at hydrostatic pressure

Because IF2 fluid inclusions clearly postdate the IF1 inclusions, they do not represent co-existing fluids and therefore do not suggest immiscibility or boiling during the W-Au event at Tighza. Increasing salinities from IF1 to IF2 inclusions do not favor mixing and dilution by meteoric fluids. The succession from $\mathrm{CO}_{2}$-rich IF1 fluid to $\mathrm{H}_{2} \mathrm{O}$ rich IF2 fluids could be explain by two models:

1) $\mathrm{CO}_{2}$-rich IF1 fluid represents metamorphic fluid associated to contact metamorphism and decarbonatation of the calcareous rocks; $\mathrm{H}_{2} \mathrm{O}$-rich moderate to high salinity IF2 fluids would represent magmatic fluids associated to the $\mathrm{Au}-\mathrm{W}$ mineralizing events; However, it seems unlikely that $\mathrm{CO}_{2}$-rich fluids, liberated by decarbonation reactions during contact metamorphism would precede exsolved magmatic brines from melt.

(2) $\mathrm{CO}_{2}$-rich and $\mathrm{H}_{2} \mathrm{O}$-rich fluids represent the sequential release of an evolving magmatic fluid: as $\mathrm{CO}_{2}$ solubility in silicate melts is very low, fluids exsolved from the crystallizing magma (IF1 and $\mathrm{W}$ stage) were initially $\mathrm{CO}_{2}$-rich followed by $\mathrm{H}_{2} \mathrm{O}$-rich fluids that carried chlorine and $\mathrm{Au}$ associated metals (IF2 and Au/Bi/Te/As stage; Fig. 15D). This process ws already proposed by Baker and Lang (2001) on the. Emerald Lake and Dublin Gulch gold deposits (Yukon).

Outside E-W corridors and horsetail termination of "W" structures, magmatic fluids circulated along permeable horizons and reacted with specific reactive stratigraphic levels, mainly Visean carbonates, forming skarns with disseminated gold and sulfides. 
Results from radiogenic isotope analyses $(\mathrm{Pb}, \mathrm{Sr}, \mathrm{Nd})$ indicate that the metals were derived from various sources that included the local granites and the surrounding Paleozoic rocks. The mobilization of lead from these rocks would have been facilitated by the large fracturing event related to the late $\mathrm{Pb}-\mathrm{Ag}-(\mathrm{Zn})$ mineralization. Although the granites may have been a minor contributor to the formation of lead mineralization, they were likely a major source for W, Mo, Te, $\mathrm{Au}$ and $\mathrm{Sn}$. Whether the basement contribution to the $\mathrm{W}$-Au event was the result of remobilization by magma genesis or residual "crustal" metamorphic fluids remains uncertain. However, a "crustal" fluid flow might have been triggered by convection cells induced by the emplacement of the underlying pluton (Eldursi et al., 2009) (Fig. 15C).

The $\mathrm{Pb}-\mathrm{Ag}-\mathrm{Zn}$ veins reflect a convective system that was emplaced long after the $\mathrm{Au}-\mathrm{W}$ mineralization (Jébrak, 1984; Wadjinny, 1998). The size of the convective system was large, extending over an area that was more than 10 times the size of the earlier three stages, and reflects a convective system large enough to homogenize lead isotope signatures at the district scale.

The superposition of the $\mathrm{Pb}-\mathrm{Zn}-\mathrm{Ag}$ hydrothermal system on the early $\mathrm{W}$ - $\mathrm{Au}$ system could be explained (1) by local uplift marked by their emplacement in a low hydrostatic pressure environment. The transtensional component of the D3 event is in need of more study, but major faults, such as the Tighza fault (Fig. 1, 3i), present numerous criteria of north-vergent normal sense of slip which might explain part of the observed uplift, or (2) by focusing of the fluid at the top of the solidified and cold intrusion, in relation with either a contrast of permeability or a contrast of thermal conductivity between the pluton and its host rocks. In the first hypothesis, gravity-induced circulation would move a single-pass fluid outward towards the periphery of the district, whereas multiple-pass fluids would circulate in-ward. The high salinity of the fluid and the lead isotopic signature are more compatible with the second model. 


\section{2 - Comparisons with the R-IRG model}

This study of the Tighza district provides a better understanding of the conditions of emplacement and the dynamics of the formation of a late-Hercynian, polymetallic $\mathrm{Au}-\mathrm{As}-\mathrm{W}-\mathrm{Pb}-\mathrm{Zn}-\mathrm{Ba}$ district. It has numerous characteristics that have been considered typical of R-IRG ore deposit model (Lang and Baker, 2001; Blevin, 2004; Hart, 2005).

\subsection{1 - Comparison of the geological setting}

The geology of IRG-type mineralization varies as a function of depth of emplacement resulting in a large diversity of geological environments including breccia, skarn, disseminated and vein-style deposits. They are associated with the presence of weakly reduced to moderately oxidised, intermediate to felsic fractionated I-type magmatism, either intermediate (i.e. granodiorite) or felsic. Granites generally fall into the field between ilmenite- and magnetite-series granites. They have subequal quartz, plagioclase and alkali feldspar with minor biotite, amphibole (biotite > amphibole), and apatite. Magnetite is rare or absent, due to low relative Fe content and/or weak oxidation state. High level rhyolites are strongly porphyritic. Granites are equigranular to porphyritic. Both are typically texturally variable and may present unidirectional solidification textures, miarolitic textures, pegmatites, vein dykes, all indicative of volatile saturation during crystallisation at mid to high crustal levels. Magmas are weakly reduced to moderately oxidised (FMQ to NNO). Alkali feldspars may be pinkish, but commonly white to greenish due to phyllic alteration proximal to mineralisation.

The Tighza district displays the same system of rapidly cooled polyphased intrusions as described in the IRG model. For example, the W-Mo event is directly associated with the Mine granite 
$(286.0+/-0.4 \mathrm{Ma})$ which is also the source of the $\mathrm{W}$ - skarns $(285.3+/-0.5 \mathrm{Ma})$ and scheelite molybdenite veins $(285.6+/-0.5 \mathrm{Ma})$.

Both the host rocks and old structures within these rocks can constrain the deposition of the metals; reduced host rocks act as traps for oxidized hydrothermal fluids; existing structures may be reactivated during granite emplacement leading to the interplay of reactivated older structures and the evolving magmatic-hydrothermal system.

\subsection{2 - Au Mineralization}

Mineralisation is marked by an association of gold with $\mathrm{Bi}$, As, W, Mo, Sb, Te. Base metal contents are highly variable; alteration is variable in both style and intensity. Zonation from the intrusion is from high temperature W-Mo (proximal) to later, lower temperature Au-As-Bi assemblages (distal). This latter assemblage occurs in vertically zoned porphyry systems and in longitudinal vein systems. Zonation on a pluton to district scale is also apparent. Gold mineralization in the Tighza district is restricted to the end of the magmatic stage. Moreover, its association with late sulfidic conditions may reflect either boiling of the hydrothermal fluids related to a change from lithostatic to hydrostatic pressure constraints, or an increase in sulfur released by the interaction of the host-rocks. Alteration styles comprise mostly a potassic (Kfeldspar, muscovite and phlogopite) locally forming greisen with $\mathrm{W}$-Au veins, and an intense silicification with skarn and skarnoid.

\subsection{3 - Genesis}

Fluid compositions are highly saline and of magmatic origin during early, pre-Au mineralisation stages. Gold mineralisation is typically associated with lower temperature, lower salinity fluids which are commonly $\mathrm{CO}_{2}$ bearing, ranging from magmatic to dominantly magmatic with variable amounts of external fluids, probably introduced into the hydrothermal system during cooling. 
Gold is typically associated with brines. Frank et al. (2002) demonstrated that gold is transported as $\mathrm{AuCl}_{2} \mathrm{H}$ and $\mathrm{Au}(\mathrm{OH})$ in a sulfur-free magmatic volatile phase exsolved from haplogranite melts at $100 \mathrm{MPa}$ and $800^{\circ} \mathrm{C}$. Gold concentrations of magmatic vapor and brine converge as the critical pressure is approached along a given isotherm (Simon et al., 2005). The depth at which a melt undergoes volatile exsolution plays therefore a critical role in the mass transfer of gold between melt and magmatic volatile phases. Low S magmas of intermediate to felsic compositions with intermediate oxidation states favour neither early sulfide or magnetite precipitation, or early $\mathrm{SO}_{2}$ formation. The absence of these conditions should be conducive to the preservation of Au in the melt fraction of granite magmas.

Table 5 - Comparison of major features between Tighza district and Hart's R-IRG model (2005)

Granite emplacement was preceded by reactivation of a shear-stress corridor that was invaded by fluids throughout the period of magmatic activity in the area, i.e. for at least $6 \mathrm{Ma}$ (291.8 to 285 Ma). This suggests a context similar to that of Clear Creek, Yukon (Stephens et al., 2000). The long duration of cooling $(291.8-285.3=6.5 \mathrm{Ma})$ implies conductive cooling of the pluton in a zone of low permeability (Cathles 1981).

\section{8 - Conclusion}

Mineralization within the Tighza polymetallic district was a multiphase process. Although the early gold-tungsten system and the large $\mathrm{Pb}-\mathrm{Zn}-\mathrm{Ag}$ vein-style system are both located at the top of a late-Hercynian plutonic system, they are clearly the product of two disconnected hydrothermal stages. This leads to propose some changes in the Lang and Baker model (2001) in its application 
to the Tighza district, such as the coeval age of $\mathrm{Au}$ and $\mathrm{Pb}-\mathrm{Zn}-\mathrm{Ag}$ mineralization in most districts. In the Tighza district, the first stage was produced over a time span of at least $5 \mathrm{Ma}$ by successive magmatic and hydrothermal pulses.

The geometry of the ore bodies is strongly dependent on the style of permeability induced in, and the reactivity of, the host rocks. For example, the $\mathrm{Au}-\mathrm{W}$ quartz veins were deposited in veins formed by sinistral movement along a fault, while fluids reacting with limestone host-rock gave birth to the As-Fe-(Au) dissemination within skarns. Deposition of tungsten and molybdenum in veins and skarns is coeval with emplacement and cooling of the Mine granite at $286 \pm 1 \mathrm{Ma}$.

This polyphased emplacement was accompanied by uplift of the basement. This conclusion is supported by field observation of deformed host-rocks, re-equilibration and spectacular explosion of early water-carbonic inclusions of the tungsten phase. This uplift is coeval with the appearance of saccharoidal quartz with multiphase fluid inclusions oversaturated in $\mathrm{NaCl}$. This second stage is a late-magmatic mineralized episode that precedes the emplacement of large hydrothermal convective cells of regional extent, responsible for the genesis of huge $\mathrm{Pb}-\mathrm{Ag}-(\mathrm{Zn})$ veins, likely during the upper Permian.

The late-Hercynian gold veins of central Morocco differ from gold-veins associated with the Hercynian terranes of France in multiple aspects: structural context, fluid origins, isotopic signatures, and younger ages (Bouchot et al., 1997, 2000, 2005). Centered on a calc-alcaline reduced intrusion, the Tighza district thus appears to be the missing link which allows an association to be made between three apparently disconnected types of ore deposits within a single district: 1) W-greisens, somewhat acid and less -developed; 2) reduced gold deposits; and 3) leadzinc-silver deposits in sediments (Beaudoin and Sangster, 1992). 


\section{Acknowledgments}

We gratefully acknowledge T. Skalli and A.Wadjinny, managers of CMT mining Company, for free access to mine and mining documents. On the mine site, we are indebted to M. Ouchtouban, H. Bounajma and M. Nasloubi for field and logistic assistance. Many thanks to A. Cheilletz for fruitful discussions. We are indebted to James Lang, whose abundant and pertinent remarks greatly improved the paper.

\section{References}

Afifi, A., Kelly, W.C., and Essene, E.J. 1988, Phase relations among tellurides, sulfides, and oxides; I, Thermochemical data and calculated equilibria: Economic Geology, v. 83, p. 377-394.

Agard, J., Balcon, J.M., and Morin, Ph., 1958, Étude géologique et métallogénique de la région minéralisée du Jbel Aouam (Maroc Central) : Notes et Mémoires du Service Géologique du Maroc, v. 132, 126 p.

Baker, T. and Lang, JR, 2001, Fluid inclusion characteristics of intrusion-related gold mineralization, Tombstone tungsten magmatic belt, Yukon Territory, Canada. Mineralium Deposita, v. 36, p. 477-489.

Bakker, R.J., 2003, Computer programs for analysis of fluid inclusion data and for modelling bulk fluid properties: Chemical Geology, 194, 1, p. $3-23$

Barbero, L., Jabaloy, A., Gomez-Ortiz, D., Perez-Pena, J.V., Rodriguez-Peces, M.J., Tejero, R., Estupinan, J., Azdimousa, A., Vazquez, M., and Asebriy, L., 2011. Evidence for surface uplift of the Atlas Moutains and the surrounding peripheral plateaux: Combining apatite fission-track results and geomorphic indicators in the Western Moroccan Meseta (coastal Variscan Paleozoic basement). Tectonophysics, v. 502, p. 90-104.

Barnes, H.L., 1997, Geochemistry of hydrothermal ore deposits. $3^{\text {rd }}$ edition, New York, John Wiley and Sons, $992 \mathrm{p}$.

Beaudouin, G., and Sangster, D.F., 1992, A descriptive model for silver-lead-zinc veins in clastic metasedimentary terranes: Economic Geology, v. 87,p. 1005-1021.

Bennasser, M., 1996, Lithostratigraphie, tectonique Hercynienne, paléochamps de contraintes tardi-hercyniennes et relation fracturation-minéralisation de la région de l'Aouam (Maroc Central oriental): Thèse $3^{\text {ème }}$ cycle, Université Mohamed V, Rabat, 300 p.

Bermanec, V., Sijaric, G., Kniewald, G. and Mandarino J.A., 2000, Gaspeite and associated Nirich minerals from veins in altered ultrabasic rocks from Dubostica, Bosnia and Herzegovina: The Canadian Mineralogist, v. 38, nº 6 , p. 1371-1376 
Blevin, P.L., 2004, Redox and compositional parameters for interpreting the granitoid metallogeny of eastern Australia: Implications for gold-rich ore systems: Resource Geology, v. 54, p. 241-252.

Blevin P.L., Chappell, B.W. and Allen, C.M., 1996, Intrusive metallogenic provinces in eastern Australia based on granite source and composition: Transactions of the Royal Society of Edinburgh, Earth Sciences, v. 87, p. 281-290.

Bermanec, V., Sijaric, G., Kniewald, G. and Mandarino J.A., 2000, Gaspeite and associated Nirich minerals from veins in altered ultrabasic rocks from Dubostica, Bosnia and Herzegovina: The Canadian Mineralogist, v. 38, nº 6 , p. 1371-1376

Bodnar, R.J., 1993. Revised equation and table for determining the freezing point depression of $\mathrm{H}_{2} \mathrm{O}-\mathrm{NaCl}$ solutions: Geochimica et Cosmochimica acta, v.57, p. 683-684.

Bodnar , J.B., and Vityk, M.O., 1994, Interpretation of microthermometric data for $\mathrm{H}_{2} \mathrm{O}-\mathrm{NaCl}$ fluid inclusions: Benedetto De Vivo and Maria Luce Frezzotti ed. Short Course of the Working Group (IMA) "Inclusions in Minerals", Pontignano-Siena, 1-4 september, p. 117-130.

Bouchot V., Milési J-P., Lescuyer J-L., Ledru P. (1997) - Les minéralisations aurifères de la France dans leur cadre géologique autour de 300 Ma. Chronique de la Recherche Minière, 528, 1362

Bouchot V., Milési J-P., Ledru P. (2000) - Crustal-scale hydrothermal palaeofield and related Variscan Au, Sb, W orogenic deposit at 310-305 Ma (French massif Central, Variscan belt). SGA News, n¹0, december 2000, 6-12

Bouchot , V., Ledru, P., Lerouge, C., Lescuyer J.L., and Milési, J.P., 2005, Late Variscan mineralizing systems related to orogenic processes: The French Massif Central: Ore Geology Reviews, v. 27, p. 169- 197.

Bowers T.S., and Helgeson, H.C., 1986, FORTRAN programs for generating fluid inclusion isochors and fugacity coefficients for the system $\mathrm{H}_{2} \mathrm{O}-\mathrm{CO}_{2}-\mathrm{NaCl}$ at high pressures and temperatures: Computer and geosciences, v. 11, p. 203-213.

Castorina, F., and Masi, U., 2000, Sr-isotopic composition of siderite for assessing the origin of mineralizing fluids: the case study from the Jebel Awam deposit (Central Morocco): Ore Geology Reviews, v.17, p. 83-89.

Cathles, L.M., 1981, Fluid flow and genesis of hydrothermal ore deposits. In: Skinner, B. J. (ed.), Economic Geology: $75^{\text {th }}$ anniversary volume, p. 424-457.

Cheilletz, A., 1983, Le contrôle structural des minéralisations filoniennes en tungstène du Djebel Aouam (Maroc Central); application au système filonien. Pb-Zn-Ag. Comptes Rendus Académie des Sciences. Paris, v. 297, p. 417-420.

Cheilletz, A., 1984, Contribution à la géologie du district polymétallique (W-Mo-Cu-Pb-Zn-Ag) du Jbel Aouam, Maroc Central : Thèse d'état, I.N.P.L., C.R.P.G., E.N.S.G. Nancy, 250 p.

Cheilletz, A. and Zimmermann, J.L., 1982, Datations par la méthode K-Ar du complexe intrusif et des minéralisations en tungstène du Djebel Aouam (Maroc central): Comptes Rendus Académie des Sciences. Paris, t. 295, série II, p. 255-258.

Cheilletz, A., and Giuliani, G., 1988, Les Skarns tungstifères stratiformes du Djebel Aouam (Maroc Central) : modèle de développement métasomatique en deux étapes. In Johan, Z. and 
Ohnenstetter, D. (coord.), Gisements métallifères dans leur contexte géologique. PIRSEM. Document BRGM 158, v.1, p. 151- 173.

Cheilletz, A., and Isnard P., 1985, Contribution à la prospection des gisements hydrothermaux de tungstène sur l'exemple du district polymétallique W-Pb-Zn-Ag du Jbel Aouam (Maroc central) : Mineralium Deposita, v. 20, p. 220-230.

Cheilletz, A., Gasquet, D., Filali, F., Archibald, D.A., and Nespolo, M., 2010, A late Triassic ${ }^{40} \mathrm{Ar} /{ }^{39} \mathrm{Ar}$ age for the El Hammam high-REE fluorite deposit (Morocco) mineralization related to the Central Atlantic Magmatic Province: Mineralium Deposita, v. 45, p. 323-330.

Cook, D.R., and McPhail, D.C., 2001, Epithermal Au-Ag-Te Mineralization, Acupan, Baguio District, Philippines: Numerical Simulations of Mineral Deposition: Economic Geology, v. 96, p. 109-131.

Desteucq, C., 1974, Le système filonien du Jbel Aouam (Maroc central); essai d'interprétation structural: Thèse $3^{\text {ème }}$ cycle, Université Paul Sabatier de Toulouse.

Dimitrova, D., and Kerestedjian, T., 2006, Bismuth minerals in the postskarn sulphide-arsenide mineralization in the Martinovo iron deposit, NW Bulgaria: Geochemistry, Mineralogy and Petrology, Sofia, v. 44, p. 19-32.

Doe, B.R., and Zartman, R.E., 1979, Plumbotectonics, the Phanerozoic. In: Geochemistry of hydrothermal ore deposits, edited by Barnes, H.L.; John Wiley and Sons, New York, p. 22-70.

Einaudi M., T., Meinert, L.D., and Newberry, R.J., 1981, Skarn deposits. Economic Geology $75^{\text {th }}$ anniversary volume, p. 317-391

El Hadi, H., Simancas Cabrera, F., Tahiri, A., González Lodeiro, F., Azor Pérez, A., and Martínez Poyatos, D.J., 2006, Comparative review of the Variscan granitoids of Morocco and Iberia: proposal of a broad zonation: Geodinamica Acta, v. 19, p. 103-116.

Eldursi, K., Branquet, Y., Guillou-Frottier, L. and Marcoux, E., 2009, Numerical investigation of transient hydrothermal processes around intrusions: Heat-transfer and fluid-circulation controlled mineralization patterns: Earth and Planetary Science Letters, v. 288, p. 70-83.

Etiope, G., Martinelli, G., 2002, Migration of carrier and trace gases in the geosphere; an overview. Physics of the Earth and Planetary Interiors, v. 129, p. 185-204.

Fogel R.A., and Rutherford M.J., 1990, The solubility of carbon dioxide in rhyolitic melts; a quantitative FTIR study: American Mineralogist, v. 75, p. 1311-132.

Frank, M.R., Candela P.A., Piccoli P.M., and Glascock, M.D., 2002, Gold solubility, speciation, and partitioning as a function of $\mathrm{HCl}$ in the brine-silicate melt-metallic gold system at $800^{\circ} \mathrm{C}$ and 100 MPa: Geochimica et Cosmochimica Acta, v. 66, 21, p. 3719-3732

Gasquet, D., Stussi, J.M., and Nachit, H., 1996, Les granitoïdes hercyniens du Maroc dans le cadre de l'évolution géodynamique régionale: Bulletin de la Société Géologique de France, v. 4, p. 517528.

Giuliani, G., Cheilletz, A., and Zimmermann, J.L, 1989, The emplacement, geochemistry and petrogenesis of two central Morocco Hercynian granites. Geotectonic implications: Journal of African Earth Sciences, v. 9, p. 617-629. 
Gloaguen, E., Chauvet, A., Branquet, Y., Gerbeaud, O., Ramboz, C., Bouchot, V., Lerouge, C., Monié, P., Cathelineau, M., Boiron M.C., Marignac, C., Pourraz, N., Fourcade, S., Ruffet, G., and Iglesias Ponce de León, M., 2003, Relations between Au/Sn-W mineralizations and late Hercynian granite: preliminary results from the Schistose Domain of Galicia-Trás-os-Montes Zone, Spain, in: Eliopoulos D. et al. (eds), 7th biennal SGA meeting - Mineral Exploration and Sustainable Development, Athens, Greece, p. 271-274.

Ghorbal, B., Bertolli, G., Foeken, J., and Andriessen, P., 2008, Unexpected Jurassic to Neogene vertical movements in 'stable' parts of NW Africa revealed by low temperature geochronology: Terra Nova, v. 20, p. 355-363.

Groves, D.I., Bierlein, F.P., Meinert, L.D., and Hitzmann, M.W., 2010, Iron oxide copper-gold (IOGC) deposits through Earth history: Implications for origin, lithospheric setting, and distinction from other epigenetic iron oxide deposits: Economic Geology, v. 105, p. 541-554.

Hart, C.J.R., 2005, Classifying, distinguishing and exploring for intrusion-related gold systems: The Gangue, v. 87, p. 1, 4-9.

Heinrich, C.A., 2007, Fluid-fluid interactions in magmatic-hydrothermal ore formation: Reviews in Mineralogy and Geochemistry, Mineralogical Society of America, v. 65, p. 361-387.

Hoepffner, C., Soulaimani, A., and Piqué, A., 2005, The Moroccan Hercynides: Journal of African Earth Sciences, v. 43, p. 144-165.

Hollister, V.F., 1992, On a proposed plutonic porphyry gold deposit model: Non-renewable Resources, v. 1, pp. 293-302.

Jébrak, M., 1984, Contribution à l'histoire naturelle des filons F-Ba des Hercynides françaises et marocaines : Document BRGM, N99,510 p.

Jébrak, M., 1984, Le district filonien à $\mathrm{Pb}-\mathrm{Zn} \mathrm{Ag}$ et carbonates du J. Aouam : Bulletin de Minéralogie, v. 108, p. 487-498.

Kempe, U., Belyatsky, B.V., Krymsky, R.S., Kremenetsky, A.A., and Ivanov, P.A. 2001, Sm-Nd and $\mathrm{Sr}$ isotope systematics of scheelite from the giant $\mathrm{Au}(-\mathrm{W})$ deposit Muruntau (Uzbekistan): implications for the age and sources of Au mineralization: Mineralium Deposita, v. 36, p. 379-392.

Knight, C.L., and Bodnar, R.J., 1989, Synthetic fluid inclusions: IX. Critical PVTX properties of NaCl- $\mathrm{H}_{2} \mathrm{O}$ solutions: Geochimica et Cosmochimica Acta, v. 53, p. 3-8.

Kretschmar, C.L. and Scott, S.D., 1976, Phase relations involving arsenopyrite in the system Fe-As-S and their applications. Canadian Mineralogist, 14: 364-386

Lang, J.R., Baker, T., Hart, C., and Mortensen, J.K., 2000, An exploration model for intrusionrelated gold systems: Society of Economic Geologists Newsletter, v. 40, p. 1, 6-14.

Lang, J.R., and Baker, T., 2001, Intrusion-related gold systems. The present level of understanding: Mineralium Deposita, v. 36, p. 477-489.

Liebscher, A., 2007, Experimental studies in model fluid systems: Review of Mineralogy and Geochemistry, v. 65, p. 15-47.

Mao, J., Konopelko, D., Seltmann, R., Lehmann, B., Chen, W., Wang, Y., Eklund, O., and Usubaliev, T., 2004, Postcollisional age of the Kumtor gold deposit and timing of Hercynian events in the Tienhan, Kyrgyztan: Economic Geology, v. 99, p. 1771-1780. 
Marcoux, E., 1987, Isotopes du plomb et paragenèses métalliques, traceurs de l'histoire des gîtes minéraux. Illustration des concepts de source, d'héritage et de régionalisme dans les gîtes français. Applications en recherche minière : Thèse Doctorat d'État, Université de Clermont-Ferrand II. Mémoire BRGM, n 117, 289 p. + annexes.

Michard, A., Soulaimani, A., Hoepffner, C., Ouanaimi, H., Baidder, L., Rjimati, E.C., and Saddiqi, O., 2010, The South-Western Branch of the Variscan Belt: Evidence from Morocco: Tectonophysics, v. 492, p. 1-24.

Morelli, R., Creaser, R.A., Seltmann, R., Stuart, F.M., Selby, D., and Graupner, T., 2007, Age and source constraints for the giant Muruntau gold deposit, Uzbekistan, from coupled Re-Os-He isotopes in arsenopyrite: Geology, v. 35, p. 795-798.

Mrini, Z., Rafi, A., Duthou, J.L., and Vidal, P., 1992, Chronologie Rb/Sr des granitoïdes hercyniens du Maroc, conséquences : Bulletin de la Société Géologique de France, v. 3, p. 281291.

Nerci, K., 2006, Les minéralisations aurifères du district polymétallique de Tighza (Maroc central): un exemple de mise en place périgranitique tardihercynienne: Thèse Université d'Orléans - Université du Québec à Montréal, 302 p.

Ntarmouchant, A., 1991, Le magmatisme hercynien de la région de Mrirt : Thèse de $3{ }^{\text {ème }}$ cycle, Université Sidi Mohamed Ben Abdellah, Fès, 169 p.

Petford, N., Cruden, A.R., McCaffrey, K.J.W. and Vigneresse J.L., 2000, Granite magma formation, transport and emplacement in the Earth's crust: Nature, p. 669-673

Piqué, A., Bossière, G., Bouillin, J.P., Chalouan, A., and Hoepffner, C., 1993, Southern margin of the Variscan belt: the north-western Gondwana mobile zone (eastern Morocco and Northern Algeria): Geologische Rundschau, v. 82, p. 432-439.

Pons, J.M. and Franchini M., 2009, Iron skarns of the Vegas Peladas District, Mendoza, Argentina: Economic Geology, v. 104, 2, p. 157-184

Ramboz, C., Schinapper, D., and Dubessy J., 1985, The P-V-T-X-fO $\mathrm{f}_{2}$ evolution of $\mathrm{H}_{2} \mathrm{O}-\mathrm{CO}_{2}-\mathrm{CH}_{4}$ bearing fluid in a wolframite vein: reconstruction from fluid inclusion studies: Geochimica et Cosmochimica Acta, v. 49, p. 205-219.

Renne, PR., Swisher, C.C., Deino, A.L., Karner, D.B., Owens, T.L., and DePaolo, D.J. 1998, Intercalibration of standards, absolute ages and uncertainties in ${ }^{40} \mathrm{Ar} /{ }^{39} \mathrm{Ar}$ dating: Chemical Geology, v. 145, p. 117-152.

Ruffet, G., Féraud, G., Ballèvre, M., and Kienast, J.R., 1995, Plateau ages and excess argon on phengites: ${ }^{40} \mathrm{Ar} /{ }^{39} \mathrm{Ar}$ laser probe study of alpine micas (Sesia zone): Chemical Geology, v. 121, p. 327-343.

Saidi, A., Tahiri, A., Aït Brahim, L., and Saidi, M., 2002, Etats de contraintes et mécanismes d'ouverture et de fermeture des bassins permiens du Maroc hercynien. L'exemple des bassins des Jebilet et des Rehamna : C.R. Géosciences, v. 334, p. 221-226.

Schaltegger, U., Stille, P., Rais, N., Piqué, A., and Clauer N., 1994, Neodymium and strontium isotopic dating of diagenesis and low-grade metamorphism of argillaceous sediments): Geochimica et Cosmochimica Acta, v. 58, p. 1471-1481. 
Sillitoe, R.H., 2000. Gold-rich porphyry deposits: descriptive and genetic models and their role in exploration and discovery: Reviews in Economic Geology, Gold in 2000. v 13, p. 315-346.

Sillitoe, R.H., and Thompson, J.F.H., 1998, Intrusion-related vein gold deposits: types, tectonomagmatic setting and difficulties of distinction from orogenic gold deposits: Resources Geology, v. 48 , p. $237-250$.

Simon, A.C., Frank, M.R., Pettke T., Candela P.A., Piccoli P.M., and Heinrich C.A., 2005 Gold partitioning in melt-vapor-brine systems: Geochimica et Cosmochimica Acta, v. 69, p. 3321-3336.

Stacey, J.D. and Kramers, J.D., 1975, Approximation of terrestrial lead isotope evolution by a twostage model: Earth and Planetary Science Letters, v. 26, p. 207-221.

Steiger, R.H., and Jäger, E., 1977, Subcommission on geochronology: convention on the use of decay constants in geo- and cosmochronology: Earth and Planetary Science Letters 36, 359-362.

Stephens, J.R., Oliver, N.H.S., Baker, T., and Hart C.H., 2000, Structural evolution and controls on gold mineralization at Clear Creek, Yukon. Yukon and Exploration Geology 1999, p. 151 - 164

Tahiri, A., Simancas, J.F., Azor, A., Galindo-Zaldivar, J., Lodero, F.G., El Hadi, H., Poyatos, D.M., and Ruiz-Constan, A. 2007, Emplacement of ellipsoid-shaped (diapiric?) granite: Structural and gravimetric analysis of the Oulmes granite (Variscan Meseta, Morocco): Journal of African Earth Sciences, v. 48, p. 301-313.

Tatsumoto, M., Knight, R.J., and Delevaux, M.H., 1972. Uranium, thorium, and lead concentrations in three silicate standards and a method of lead isotopic analysis: USGS Professional Paper, v. 800-D, p. 111-115.

Thiery, R., Vidal, J., and Dubessy, J., 1994, Phase equilibria modelling applied to fluid inclusions: liquid-vapour equilibria and calculation of the molar volume in the $\mathrm{CO}_{2}-\mathrm{CH}_{4}-\mathrm{N}_{2}$ system: Geochimica et Cosmochimica Acta, v. 58, p. 1073-1082

Thompson, J.F.G., Sillitoe, R.H., Baker, T., Lang, J.R., and Mortensen, J.K., 1999, Intrusionrelated gold deposits associated with tungsten-tin provinces: Mineralium Deposita, v. 34, p. 323344.

Todt, W., Cliff, R.A., Hanser, A., and Hofmann, A.W., 1984, ${ }^{202} \mathrm{~Pb}-{ }^{205} \mathrm{~Pb}$ spike for $\mathrm{Pb}$ isotopic analysis: Terra Cognita, v. 4, p. 209.

Tombros, S., Seymour, K.S., and Williams-Jones, A.E., 2010, Controls of Tellurium in Base, Precious and Telluride Minerals in the Panormos Bay Ag-Au-Te deposits, Tinos island, Cyclades, Greece: Economic Geology, v. 105, p. 1097-1112.

Vaughan, D.J., and Craig, J.R., 1997, Sulfide ore mineral stabilities, morphologies and intergrowth textures, In: Geochemistry of hydrothermal ore deposits, edited by Barnes, H.L.; 3rd edition, New York, John Wiley and Sons, p. 367-434

Voicu, G., Bardoux, M., Stevenson, R., and Jébrak., M. 2000, Nd and Sr isotope study of hydrothermal scheelite and host rocks at Omai, Guiana Shield: implications for ore fluid source and flow path during the formation of orogenic gold deposits: Mineralium Deposita, v. 35, p. 302314.

Wadjinny, A., 1998, Le plomb au Maroc: cas des districts de Touissit et de Jbel Aouam: Chronique de la Recherche Minière, v. 531-532, p. 9-28. 
Wall, V.J., and Taylor, J.R., 1991, Thermal aureole gold - Victoria and elsewhere. Selwyn Memorial lecture. Series; Melbourne. http://www.vic.gsa.org.au/Selwyn/past_symposiums/Selwyn1991/Selwyn1991Wall/Selwyn1991 Wall.pdf. 4 p.

Watanabe, Y., 2002, ${ }^{40} \mathrm{Ar} /{ }^{39} \mathrm{Ar}$ Geochronologic Constraints on the Timing of Massive Sulfide and Vein-Type Pb-Zn Mineralization in the Western Meseta of Morocco. Economic Geology, v. 97, p. 145-157.

Whalen, J.B. and Chapell, B.W., 1988, Opaque mineralogy and mafic mineral chemistry of I- and S-type granites of the Lachlan fold belt, Southeast Australia: American Mineralogist, v. 73, p. 281296. 


\section{Annexe 1: Methodologies}

\section{Fluid inclusions}

\section{Methodology}

Fluid inclusions were carried out using a Chaix-Meca system. Low temperature standards included Campeirio quartz, sea-water and pure synthetic fluid inclusions whereas high temperature standards consisted of lead orthophosphate and a critical water biphasic fluid inclusion in a synthetic quartz. After calibration, precision is $<0.1{ }^{\circ} \mathrm{C}\left(-60^{\circ}-0^{\circ} \mathrm{C}\right.$ range) for low temperatures whereas it is $<1^{\circ} \mathrm{C}$ for high temperatures $\left(200^{\circ}-400^{\circ} \mathrm{C}\right.$ range $)$. Cycled heating and cooling were used for observing clathrate formation and dissolution. Raman spectroscopy was used for the determination of solids, fluids and gas within fluid inclusions.

\section{Radiogenic isotopes}

\section{Rb-Sr, Sm-Nd}

$\mathrm{Rb}-\mathrm{Sr}, \mathrm{Sm}-\mathrm{Nd}$ isotopic data were obtained from scheelite and whole-rock samples analyzed at the GEOTOP Radiogenic Isotope Laboratories at the Université du Québec à Montréal (UQAM) in order to constrain the sources of the mineralization (Voicu et al., 2000, Kempe et al., 2001). Scheelite was concentrated from vein material by passing crushed vein material through heavy liquids, magnetic separation and, finally hand-picking under a binocular microscope. The resulting mineral fraction was washed in dilute hydrochloric acid $(\mathrm{HCl})$ to remove any carbonate material, then rinsed in distilled water to remove the acid and left to dry. The scheelite fractions were ground to a fine powder in an agate mortar and whole-rock samples were similarly ground in an agate puck-mill. Chemical separation procedures for $\mathrm{Nd}$ and $\mathrm{Sr}$ isotopes were conducted under clean lab conditions and all acids were distilled. In each case, between 50 and $100 \mathrm{mg}$ of powdered 
sample were weighed out into a Teflon Parr-bomb and spiked with a ${ }^{150} \mathrm{Nd}-{ }^{149} \mathrm{Sm}$ tracer solution for the determination of $\mathrm{Sm}$ and $\mathrm{Nd}$ concentrations. A mixture of $\mathrm{HF}-\mathrm{HNO}_{3}$ acids was added and the mixture placed in an oven in order to dissolve the samples under pressure at a temperature of $150^{\circ} \mathrm{C}$. After one week, the samples were removed from the furnace and evaporated. The samples were subsequently evaporated in perchloric acid to break up the fluoride salts and redissolved in 6 M HCL in the oven again for 12 hours. The resulting $6 \mathrm{M} \mathrm{HCL}$ solution was loaded onto ionexchange columns containing AG1X8 resin that retained the Fe in the sample but allowing the other elements to be eluted with $6 \mathrm{M} \mathrm{HCL}$. The samples were evaporated and $0.5 \mathrm{ml}$ of $14 \mathrm{M}$ $\mathrm{HNO}_{3}$ was added to change the $\mathrm{HCl}$ salts into nitrates. The REE and $\mathrm{Sr}$ separation requires an $\mathrm{Fe}-$ free solution. This was achieved using by passing the $6 \mathrm{~N} \mathrm{HCl}$ solutions through an anion exchange resin (AG X-1) that retains the iron. Sr and REE fractions were then concentrated using Eichrom TRU Spec resin. Sr was subsequently purified using Eichrom Sr Spec resin and Sm and Nd separation was achieved using columns containing Eichrom LN Spec resin.

The isotopic composition and concentration of $\mathrm{Nd}, \mathrm{Sm}$, and $\mathrm{Sr}$ were analysed by thermal ionisation mass spectrometry (TIMS). $\mathrm{Nd}$ and $\mathrm{Sm}$ were measured using a triple filament assemblage with the samples evaporated on Ta side filaments and ionized by a Re centre filament. Sr samples were loaded and analysed on a single Re centre filament. The $\mathrm{Nd}$ and $\mathrm{Sr}$ samples were measured in dynamic mode and normalized to ${ }^{146} \mathrm{Nd} /{ }^{144} \mathrm{Nd}=0.7219$ and ${ }^{86} \mathrm{Sr} /{ }^{88} \mathrm{Sr}=0.1194$ assuming exponential fractionation behaviour while $\mathrm{Sm}$ was measured in static mode. During the period of this study, repeated measurements of the Nd International Standard JNdi yielded a value of ${ }^{143} \mathrm{Nd} /{ }^{144} \mathrm{Nd}=0.512148 \pm 11(\mathrm{~N}=11)$ compared to the published value of $0.512115 \pm 7$ (Tanaka et al., 2000). Our samples were corrected by 0.000033 for taking into account the shift of the measured standard. Repeated analysis of the NBS $987 \mathrm{Sr}$ standard yielded a value of ${ }^{87} \mathrm{Sr} /{ }^{88} \mathrm{Sr}=$ $0.710263 \pm 17(\mathrm{~N}=7)$. Epsilon $\mathrm{Nd}$ values were calculated using the present day CHUR value of 
0.512635 for ${ }^{143} \mathrm{Nd} /{ }^{144} \mathrm{Nd}$ and a ${ }^{147} \mathrm{Sm} /{ }^{144} \mathrm{Nd}=0.1967$. The typical combined procedure blanks for $\mathrm{Nd}$ and $\mathrm{Sm}$ are $<150 \mathrm{pg}$.

\section{Ar/Ar}

Four samples of phyllosilicates, two muscovites from a scheelite skarn (NK 222) and a molybdenite-scheelite vein (NK 220), both from underground works, and two biotites from Mine granite (NK 211) and W1 north vein (NK 313) were analysed with a ${ }^{39} \mathrm{Ar}-{ }^{40} \mathrm{Ar}$ laser probe $\left(\mathrm{CO}_{2}\right.$ Synrad®). Two other samples (muscovite from W1 north vein and from greisen intragranite) gave no exploitable results.

Individual mineral grains were handpicked under a binocular microscope from crushed rocks (0.3$2 \mathrm{~mm}$ fraction). Selected grains were wrapped in A1 foil to form packets $(11 \mathrm{~mm} \times 11 \mathrm{~mm} \times 0.5$ $\mathrm{mm})$. These packets were stacked up to form a pile, within which packets of flux monitors were inserted every 10 samples. The stack was inserted in an irradiation can and was irradiated at the McMaster reactor (Hamilton, Canada). The irradiation standard was sanidine TCR-2 (28.34 Ma according to Renne et al., 1998). The sample arrangement allowed us to monitor the flux gradient with a precision of $\pm 0.2 \%$.

The step-heating experimental procedure is described in detail in Ruffet et al. (1995, 1997). Blanks are performed routinely each first or third run, and are subtracted from the subsequent sample gas fractions. Analyses are performed on a Map215® mass spectrometer. To define a plateau age, a minimum of three consecutive steps are required, corresponding to a minimum of $70 \%$ of the total ${ }^{39} \mathrm{ArK}$ released, and the individual fraction ages should agree to within $1 \sigma$ or $2 \sigma$ with the integrated age of the plateau segment. All discussed ${ }^{39} \mathrm{Ar}-{ }^{40} \mathrm{Ar}$ results are displayed at the $1 \sigma$ level. Pseudo-plateau ages, with less than $70 \%$ of ${ }^{39}$ ArK released, can also be defined (Table 2). 


\section{$\mathbf{P b}$}

Analytical procedures are summarized herein. Between 10 and 20 milligrams of sulfide powder

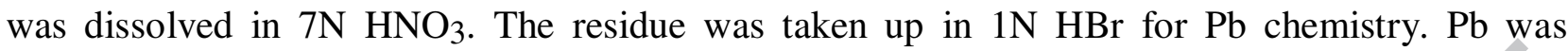
separated in Bio-Rad 10-ml polyethylene columns and Dowex AG1-8X anion resin, using 1N HBR to elute other elements and $6 \mathrm{~N} \mathrm{HCl}$ to elute $\mathrm{Pb}$. Total procedural blanks for $\mathrm{Pb}$ are $<250$ picograms. Samples were loaded onto single Re filaments with $\mathrm{H}_{3} \mathrm{PO}_{4}$ and silica gel, and were run at filament temperatures of $1175-1225^{\circ} \mathrm{C}$. Analysis of USGS Standard BCR-1 yields $\mathrm{Pb}=13.56$ ppm, $\mathrm{U}=1.70 \mathrm{ppm}, \mathrm{Th}=5.86 \mathrm{ppm},{ }^{206} \mathrm{~Pb} /{ }^{204} \mathrm{~Pb}=18.818,{ }^{207} \mathrm{~Pb} /{ }^{204} \mathrm{~Pb}=15.633$, and ${ }^{208} \mathrm{~Pb} /{ }^{204} \mathrm{~Pb}=38.633$ (average of 2 runs, see Tatsumoto et al., 1972). All mass spectrometer runs were corrected for fractionation using NIST SRM981. The average ratios measured for SRM981 on the new Triton Mass spectrometer are ${ }^{206} \mathrm{~Pb} /{ }^{204} \mathrm{~Pb}=16.892 \pm 0.010,{ }^{207} \mathrm{~Pb} /{ }^{204} \mathrm{~Pb}=15.432 \pm$ 0.013 , and ${ }^{208} \mathrm{~Pb} /{ }^{204} \mathrm{~Pb}=36.512 \pm 0.038$ (2 s.d.), based on 15 runs. The fractionation correction, based on the values of Todt et al. (1984) is $+0.13 \%$ amu.

Annexe 2 - Microprobe analysis of arsenopyrite, pyrrhotite, loellingite and sphalerite from Tighza. Microprobe CAMEBAX SX 50, ISTO - BRGM laboratory, Orléans, France 


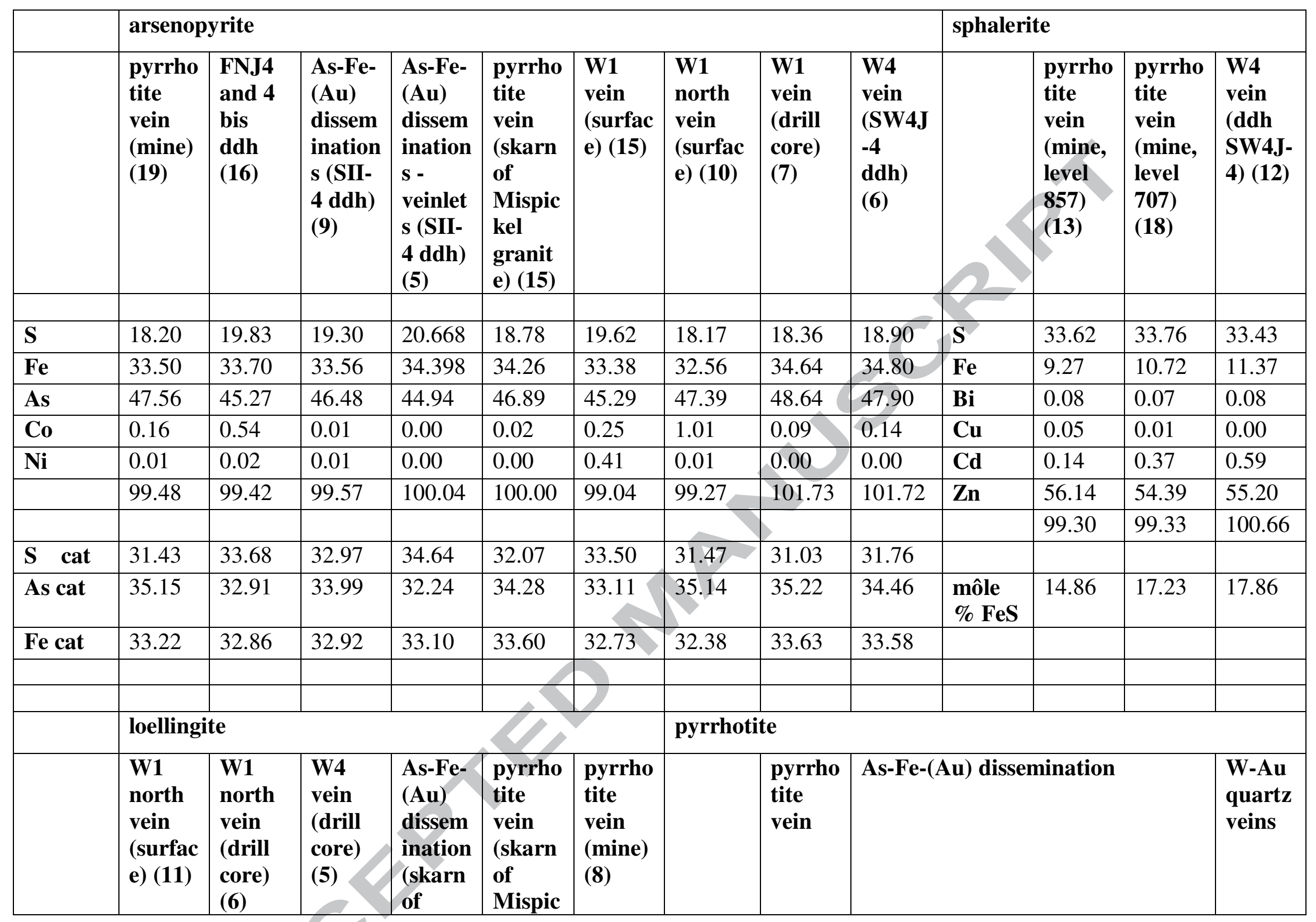




\begin{tabular}{|c|c|c|c|c|c|c|c|c|c|c|c|c|c|}
\hline & & & & $\begin{array}{l}\text { Kaolin } \\
\text { granit } \\
\text { e) (4) }\end{array}$ & $\begin{array}{l}\text { kel } \\
\text { granit } \\
\text { e) (3) }\end{array}$ & & & & & & & & \\
\hline & & & & & & & & $\begin{array}{l}\text { mine } \\
(29)\end{array}$ & $\begin{array}{l}\text { Skarn } \\
\text { of } \\
\text { Kaolin } \\
\text { granit } \\
\text { e (ddh } \\
\text { S II-4) } \\
\text { (12) }\end{array}$ & $\begin{array}{l}\begin{array}{l}\text { skarn } \\
\text { of }\end{array} \\
\text { Kaolin } \\
\text { granit } \\
\text { e } \\
\text { (surfac } \\
\text { e) (4) }\end{array}$ & $\begin{array}{l}\text { Mispic } \\
\text { kel } \\
\text { granit } \\
\text { e (ddh } \\
\text { FNJ-4) } \\
(13)\end{array}$ & $\begin{array}{l}\text { Mispic } \\
\text { kel } \\
\text { granit } \\
\text { e, } \\
\text { surfac } \\
\text { e (9) }\end{array}$ & $\begin{array}{l}\text { surfac } \\
\text { e (13) }\end{array}$ \\
\hline $\mathbf{S}$ & 1.65 & 1.72 & 2.01 & 0.55 & 1.98 & 2.34 & & & & & & & \\
\hline $\mathbf{F e}$ & 26.79 & 28.57 & 28.57 & 14.80 & 28.64 & 27.52 & $\mathrm{~S}$ anion & 54.16 & 54.28 & 54.16 & 54.15 & 53.23 & 53.36 \\
\hline As & 69.64 & 70.81 & 71.09 & 70.12 & 69.28 & 69.80 & $\begin{array}{l}\text { (Fe+Co } \\
+\mathrm{Ni}) \\
\text { cation }\end{array}$ & 45.77 & 45.62 & 45.77 & 45.78 & 46.71 & 46.56 \\
\hline & 99.05 & 101.12 & 102.11 & 99.09 & 99.90 & 100.31 & 1 & & & & & & \\
\hline & & & & & & ( & & & & & & & \\
\hline & \multicolumn{8}{|c|}{ Bismuth sulfides (W1 north vein, ddh SW1N 3b, 56m) } & & & & & \\
\hline & $\begin{array}{l}\text { joséite } \\
\text { B }\end{array}$ & $\begin{array}{l}\text { joséite } \\
\text { B }\end{array}$ & $\begin{array}{l}\text { joséite } \\
\text { B }\end{array}$ & $\begin{array}{l}\text { joséite } \\
\text { B }\end{array}$ & $\begin{array}{l}\text { joséite } \\
\text { B }\end{array}$ & $\begin{array}{l}\text { hedleyi } \\
\text { te }\end{array}$ & $\begin{array}{l}\text { hedleyi } \\
\text { te }\end{array}$ & $\begin{array}{l}\text { hedleyi } \\
\text { te }\end{array}$ & & & & & \\
\hline & 2.92 & 2.90 & 2.59 & 2.81 & 2.81 & 0.00 & 0.07 & 0.02 & & & & & \\
\hline $\mathbf{S}$ & 0.24 & 0.10 & 0.09 & 0.24 & 0.07 & 0.22 & 0.28 & 0.22 & & & & & \\
\hline $\mathbf{S b}$ & 0.04 & 0.00 & 0.03 & 0.27 & 0.10 & 0.12 & 0.05 & 0.13 & & & & & \\
\hline Se & 75.33 & 74.06 & 76.62 & 74.89 & 72.99 & 80.42 & 77.51 & 79.87 & & & & & \\
\hline
\end{tabular}




\begin{tabular}{|c|c|c|c|}
\hline Sample & Analysed mineral & \% AP & Conventionnel age \\
\hline $\begin{array}{c}\text { Molybdenite vein } \\
\text { (mine level 707 (NK } \\
\text { 220) }\end{array}$ & Muscovite & 98,3 & $285.6 \pm 0.5 \mathrm{Ma}$ \\
\hline $\begin{array}{c}\text { W-skarnoid (mine } \\
\text { level 707) (NK 222) }\end{array}$ & Muscovite & 97,3 & $285.3 \pm 0.5 \mathrm{Ma}$ \\
\hline $\begin{array}{c}\text { Mine granite } \\
\text { (surface) (NK 211) }\end{array}$ & Biotite & 98,9 & $286.0 \pm 0.4 \mathrm{Ma}$ \\
\hline $\begin{array}{c}\text { W1 north vein } \\
\text { surface gallery) (NK } \\
\text { 313) }\end{array}$ & Biotite & 91.4 & $291.8 \pm 0.3 \mathrm{Ma}$ \\
\hline
\end{tabular}


ACCEPTED MANUSCRIPT

\begin{tabular}{|c|c|c|c|c|}
\hline Sample & Analyzed material & $\begin{array}{l}{ }^{206} \mathrm{~Pb} \\
\rho^{204} \mathrm{~Pb}\end{array}$ & $\begin{array}{l}{ }^{207} \mathrm{~Pb} / \\
{ }^{204} \mathrm{~Pb}\end{array}$ & $\begin{array}{l}{ }^{208} \mathrm{~Pb} / \\
{ }^{204} \mathrm{~Pb}\end{array}$ \\
\hline \multicolumn{5}{|l|}{ Au-W veins } \\
\hline W1 vein & $\begin{array}{l}\text { Pb-rich polymetallic } \\
\text { sulphides }\end{array}$ & 18.298 & 15.668 & 38.497 \\
\hline W1 North vein & $\begin{array}{l}\text { Pb-rich polymetallic } \\
\text { sulphides }\end{array}$ & 18.351 & 15.669 & 38.383 \\
\hline W1 North vein & $\begin{array}{l}\text { Pb-rich polymetallic } \\
\text { sulphides }\end{array}$ & 18.343 & 15.660 & 38.425 \\
\hline W1 North vein & $\begin{array}{l}\text { Pb-rich polymetallic } \\
\text { sulphides }\end{array}$ & 18.335 & 15.629 & 38.329 \\
\hline W5 vein & $\mathrm{Pb}$-rich polymetallic & 18.286 & 15.680 & 38.534 \\
\hline W5 vein & $\begin{array}{l}\text { Pb-rich polymetallic } \\
\text { sulphides }\end{array}$ & 18.417 & 15.653 & 38.428 \\
\hline
\end{tabular}




\section{ACCEPTED MANUSCRIPT}

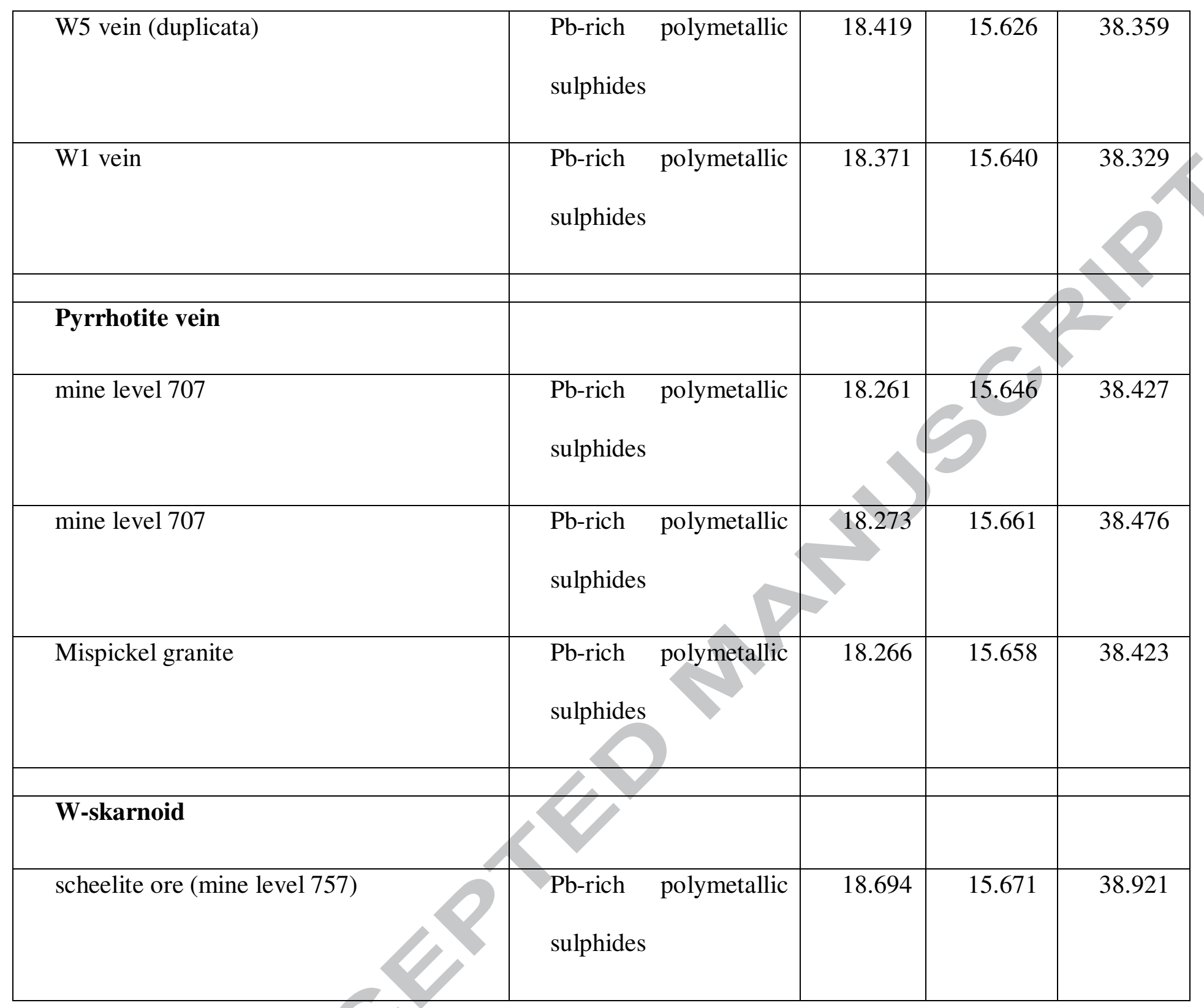




\section{ACCEPTED MANUSCRIPT}

\begin{tabular}{|c|c|c|c|c|}
\hline scheelite ore (mine level 757) & $\begin{array}{l}\text { Pb-rich polymetallic } \\
\text { sulphides }\end{array}$ & 18.875 & 15.686 & 38.613 \\
\hline \multicolumn{5}{|l|}{ As-Fe-(Au) dissemination } \\
\hline Kaolin granite (drill-hole S-II-4 136 m) & $\begin{array}{l}\text { Pb-rich polymetallic } \\
\text { sulphides }\end{array}$ & 18.299 & 15.643 & 38.490 \\
\hline Kaolin granite (drill-hole S-II-4 133 m) & $\begin{array}{l}\text { Pb-rich polymetallic } \\
\text { sulphides }\end{array}$ & 18.323 & 15.636 & 38.568 \\
\hline Kaolin granite (drill hole S-II-4 138 m) & $\begin{array}{l}\text { Pb-rich polymetallic } \\
\text { sulphides }\end{array}$ & 18.297 & 15.642 & 38.504 \\
\hline $\begin{array}{l}\text { Mispickel granite (drill- hole FNJ-4bis } 95 \\
\text { m) }\end{array}$ & $\begin{array}{l}\text { Pb-rich polymetallic } \\
\text { sulphides }\end{array}$ & 18.319 & 15.667 & 38.582 \\
\hline Mispickel granite (drill-hole FNJ-4 298 m) & Pb-rich polymetallic & 18.343 & 15.656 & 38.608 \\
\hline Pb-Ag-Zn veins & & & & \\
\hline
\end{tabular}




\section{ACCEPTED MANUSCRIPT}

\begin{tabular}{|c|c|c|c|c|}
\hline Sidi Ahmed vein & galena & 18.291 & 15.689 & 38.559 \\
\hline Sidi Ahmed vein & galena & 18.264 & 15.676 & 38.519 \\
\hline Sidi Ahmed vein & galena & 18.294 & 15.710 & 38.623 \\
\hline barytine vein & galena & 18.274 & 15.673 & 38.518 \\
\hline & & & & $y$ \\
\hline Signal vein (1) & galena & 18.261 & 15.682 & 38.508 \\
\hline Signal vein (1) & galena & 18.259 & 15.675 & 38.485 \\
\hline Signal vein (1) & galena & 18.248 & 15.661 & 38.439 \\
\hline Signal vein (1) & galena & 18.283 & 15.696 & 38.556 \\
\hline Sidi Ahmed vein (1) & galena & 18.232 & 15.652 & 38.412 \\
\hline Iguer Oujna vein (1) & galena & 18.257 & 15.651 & 38.404 \\
\hline \multicolumn{5}{|l|}{ Rocks } \\
\hline Mine granite & K-feldspar & 18.300 & 15.704 & 38.621 \\
\hline Mispickel granite & K-feldspar & 18.280 & 15.696 & 38.583 \\
\hline
\end{tabular}


ACCEPTED MANUSCRIPT

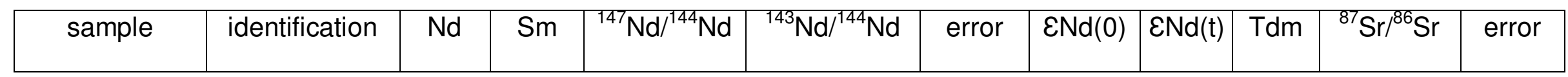

\section{whole rock}

\begin{tabular}{|c|c|c|c|c|c|c|c|c|c|c|c|}
\hline NK216a (b7) & granite mispickel & 28.3 & 5.04 & 0.1078 & 0.512333 & 0.000012 & -6.0 & -2.5 & 1.2 & $0.70420^{a}$ & 0.00002 \\
\hline NK211 (b6) & Mine granite & 21.9 & 4.01 & 0.1109 & 0.512451 & 0.000016 & -3.6 & -0.4 & 1.0 & $0.70997^{0}$ & 0.00001 \\
\hline NK210 (b4) & greisen & 25.0 & 3.98 & 0.0963 & 0.512402 & 0.000008 & -4.6 & -0.8 & 1.0 & & \\
\hline NK206 (b3) & microtrondhjemite & 25.5 & 4.52 & 0.1069 & 0.512416 & 0.000010 & -4.3 & -0.9 & 1.0 & $0.70802^{C}$ & 0.00002 \\
\hline NK204 (b2) & rhyolite & 31.0 & 6.25 & 0.1217 & 0.512302 & 0.000011 & -6.6 & -3.7 & 1.4 & & \\
\hline
\end{tabular}

\section{scheelite}

\begin{tabular}{|c|c|c|c|c|c|c|c|c|c|c|}
\hline NK202 (b31) & W5 Au-W vein & 311 & 103 & 0.1995 & 0.512277 & 0.000007 & -7.0 & -7.2 & 0.71364 & 0.00002 \\
\hline NK203 (b32) & W4 Au-W vein & 380 & 129 & 0.2056 & 0.512220 & 0.000008 & -8.2 & -8.5 & 0.71038 & 0.00001 \\
\hline NK208 (b33) & WO3 Au-W vein & 215 & 77.7 & 0.2183 & 0.512289 & 0.000010 & -6.8 & -7.6 & 0.71219 & 0.00002 \\
\hline NK218 (b34)\# & stockwerk W & 334 & 119 & 0.2145 & 0.512329 & 0.000010 & -6.0 & -6.7 & 0.71118 & 0.00002 \\
\hline NK220 (b35)* & W-Mo quartz vein & 636 & 196 & 0.1862 & 0.512513 & 0.000009 & -2.4 & -2.0 & 0.70897 & 0.00002 \\
\hline NK221 (b36)* & W-skarn vein & 577 & 198 & 0.2071 & 0.512297 & 0.000009 & -6.7 & -7.1 & 0.71122 & 0.00002 \\
\hline NK222 (b37)* & W-skarn vein & 654 & 213 & 0.1971 & 0.512246 & 0.000007 & -7.6 & -7.7 & 0.71194 & 0.00002 \\
\hline
\end{tabular}

a: 297 ppm Sr; 382 ppm Rb; 3.715: ${ }^{85} \mathrm{Rb} /{ }^{86} \mathrm{Sr} ; 0.72006:{ }^{87} \mathrm{Sr} /{ }^{86} \mathrm{Sr}$ measured b: 266 ppm Sr; 124 ppm Rb; 1.356: ${ }^{85} \mathrm{Rb} /{ }^{86} \mathrm{Sr} ; 0.71576:{ }^{87} \mathrm{Sr} /{ }^{86} \mathrm{Sr}$ measured c: $301 \mathrm{ppm}$ Sr; 245 ppm Rb; $2.361:{ }^{85} \mathrm{Rb} /{ }^{86} \mathrm{Sr} ; 0.71809:{ }^{87} \mathrm{Sr} /{ }^{86} \mathrm{Sr}$ measured *Mine level 757; \# mispickel granite age for calculation is in billion years 


\begin{tabular}{|c|c|c|c|}
\hline \multirow[b]{2}{*}{ Features } & \multirow[b]{2}{*}{$\begin{array}{l}\text { Common to R-IRGD } \\
\text { (compiled from Hart, 2005; Lang and Baker, } \\
\text { 2001; Thompson et al., 1999) }\end{array}$} & \multicolumn{2}{|c|}{ Tighza (this study) } \\
\hline & & $Y / N$ & $\begin{array}{l}\text { specific } \\
\text { characteristics and } \\
\text { comments }\end{array}$ \\
\hline Tectonic setting & $\begin{array}{l}\text { Ancient continental margins behind accretionary } \\
\text { or collisional orogens and subduction-related } \\
\text { magmatic arcs } \\
\text { Preferred host strata include reducing basinal } \\
\text { miogeoclinal sedimentary or metasedimentary } \\
\text { rocks } \\
\text { Intrusions are undeformed as they were intruded } \\
\text { millions of years after regional deformation }\end{array}$ & & $\begin{array}{l}\text { Location within the } \\
\text { Mesetan variscan } \\
\text { bloc which } \\
\text { corresponds to an } \\
\text { external zone } \\
\text { (characterized by } \\
\text { HT-LP } \\
\text { metamorphism) of } \\
\text { the variscan } \\
\text { orogeny (Michard } \\
\text { et al., 2008) }\end{array}$ \\
\hline Intrusion & $\begin{array}{l}\text { Metaluminous, subalkalic intrusion of } \\
\text { intermediate to felsic compositions that lie near } \\
\text { the boundary between ilmenite and magnetite } \\
\text { series } \\
\text { Mineralizing plutons have "smoking gun" } \\
\text { characteristics that indicate the likelihood of } \\
\text { generation of hydrothermal fluids. Physical } \\
\text { features and geochemical support should exist } \\
\text { for high volatile contents, fluid exsolution, } \\
\text { evidence of rapid fractionation, zoned plutons, } \\
\text { porphyry textures, presence of aplite and } \\
\text { pegmatite dykes, quartz and tourmaline veins, } \\
\text { greisen alteration, miarolitic cavities and/or } \\
\text { unidirectional-solidification textures, preferably } \\
\text { in the plutons' apexes }\end{array}$ & $\sqrt{ }$ & $\begin{array}{l}\text { Many similarities, } \\
\text { among which calc- } \\
\text { alkaline granite } \\
\text { belong to ilmenite- } \\
\text { series, and greisen } \\
\text { alteration }\end{array}$ \\
\hline
\end{tabular}




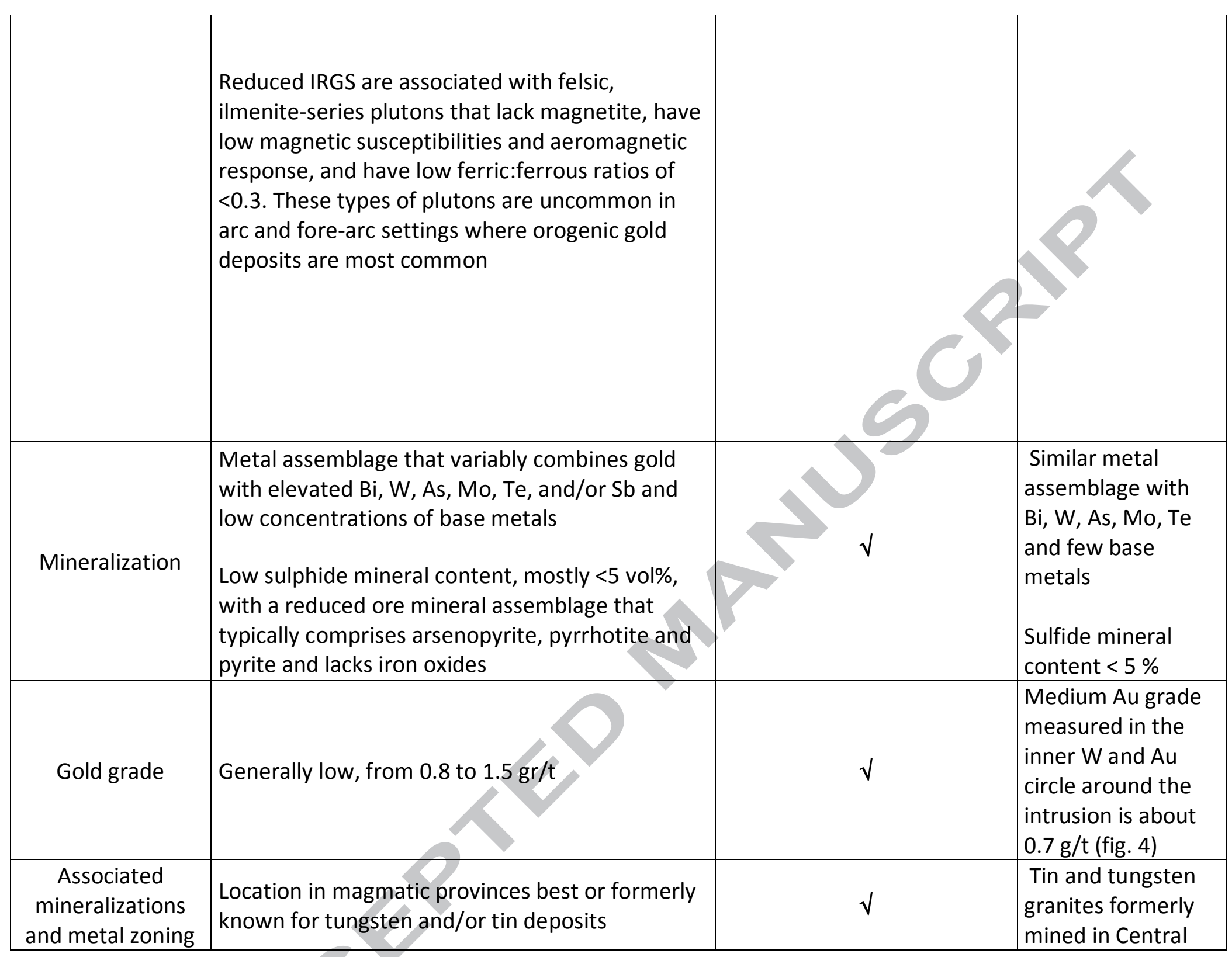




\begin{tabular}{|c|c|c|c|}
\hline & & & Morocco \\
\hline & $\begin{array}{l}\text { Thermal gradients surrounding cooling plutons } \\
\text { are steep and result in temperature-dependent } \\
\text { concentric metal zones that develop outward } \\
\text { from pluton margins for distances up to a few } \\
\text { kilometres, or just beyond the thermal aureole. } \\
\text { Pluton-proximal gold mineralization may be } \\
\text { associated with } \mathrm{Bi}, \mathrm{Te} \text {, and } \mathrm{W} \text { aureole-hosted } \\
\text { mineralization will have an As or } \mathrm{Sb} \text { tenor, and } \\
\text { distal mineralization may be related to } \mathrm{Ag}-\mathrm{Pb}-\mathrm{Zn}\end{array}$ & $\sqrt{ }$ & $\begin{array}{l}\text { Same thermal and } \\
\text { zonation patterns } \\
\text { (fig. } 2,3 \text { ) }\end{array}$ \\
\hline Fluids & Carbonic hydrothermal fluids & $\sqrt{ }$ & idem \\
\hline $\begin{array}{l}\text { Hydrothermal } \\
\text { alteration }\end{array}$ & Weak & & $\begin{array}{l}\text { Weak and of few } \\
\text { extension }\end{array}$ \\
\hline \multirow[b]{2}{*}{$\begin{array}{l}\text { Deposits type and } \\
\text { structures }\end{array}$} & $\begin{array}{l}\text { Wide range of mineralization styles around } \\
\text { and/or within the intrusion: skarns, } \\
\text { replacements, disseminations, stockworks and } \\
\text { veins }\end{array}$ & & $\begin{array}{l}\text { Wide range of } \\
\text { mineralization }\end{array}$ \\
\hline & $\begin{array}{l}\text { Sheeted Veins The most distinctive style of gold } \\
\text { mineralization are sheeted arrays of parallel, } \\
\text { low-sulphide, single-stage quartz veins which are } \\
\text { found over } 10 \text { s to } 100 \text { s of metres and } \\
\text { preferentially located in the pluton's cupola (Fig. } \\
\text { 3). These veins are unlike multidirectional } \\
\text { interconnected stockworks characteristic of } \\
\text { porphyry systems or antithetic tensional vein } \\
\text { arrays typical of orogenic gold deposits }\end{array}$ & $\sqrt{ }$ & $\begin{array}{l}\text { Wide Au-quartz } \\
\text { veins instead of } \\
\text { sheeted Au-veins } \\
\text { due to the pre- } \\
\text { existing presence } \\
\text { of faults }\end{array}$ \\
\hline Timing & $\begin{array}{l}\text { Intrusion-related deposits are coeval ( } \pm 2 \text { m.y.) } \\
\text { with their associated, causative pluton. }\end{array}$ & $\sqrt{ }$ & $\begin{array}{l}\text { Same age for both } \\
\text { intrusion-related } \\
\text { deposit and }\end{array}$ \\
\hline
\end{tabular}




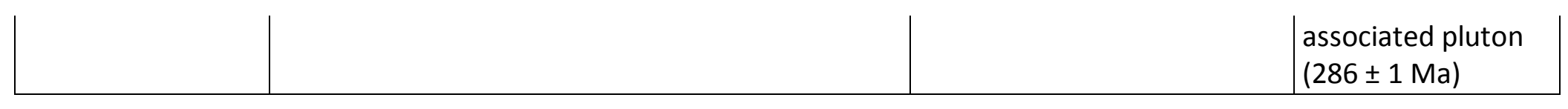




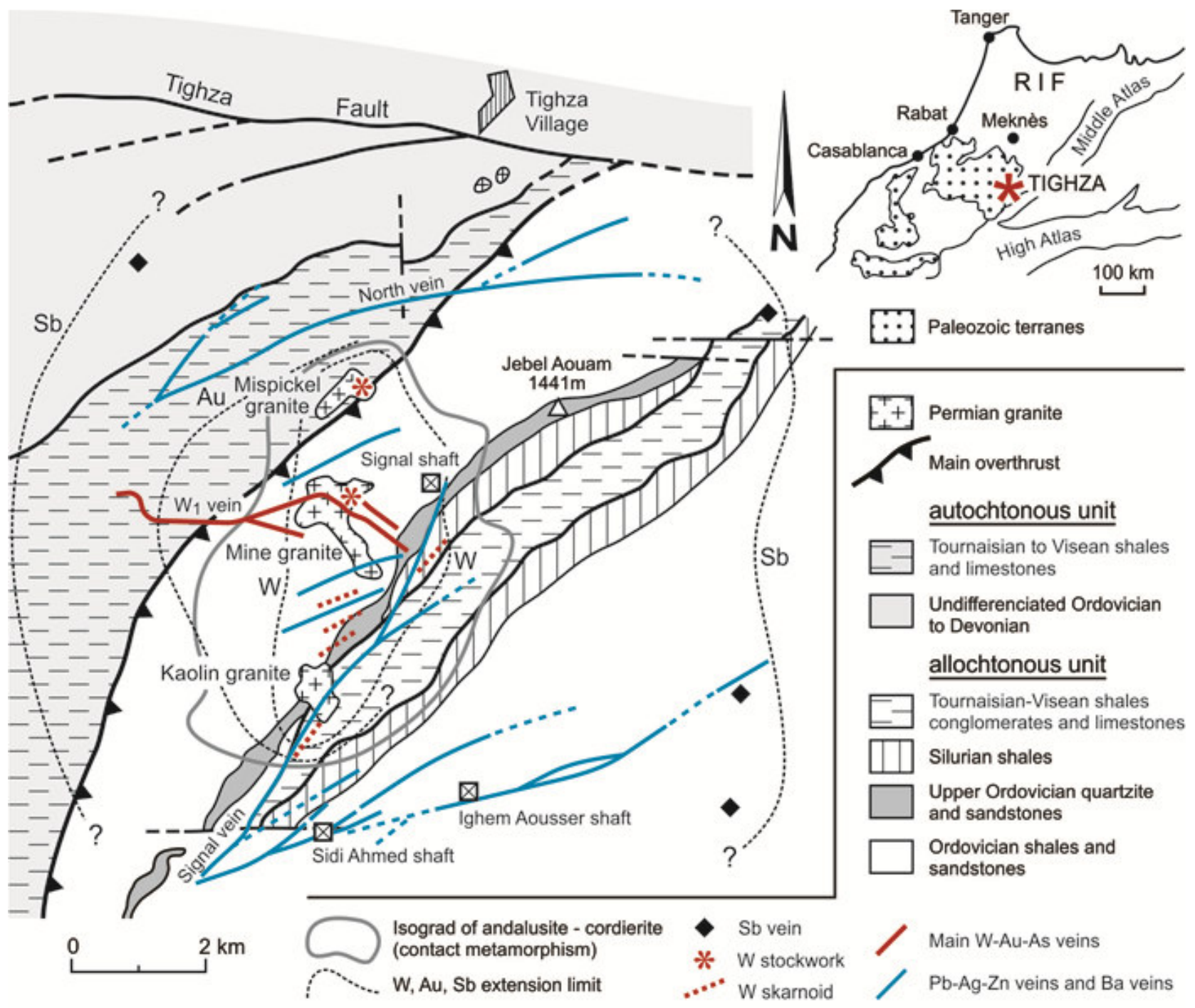

figure $n^{\circ} 1$ 


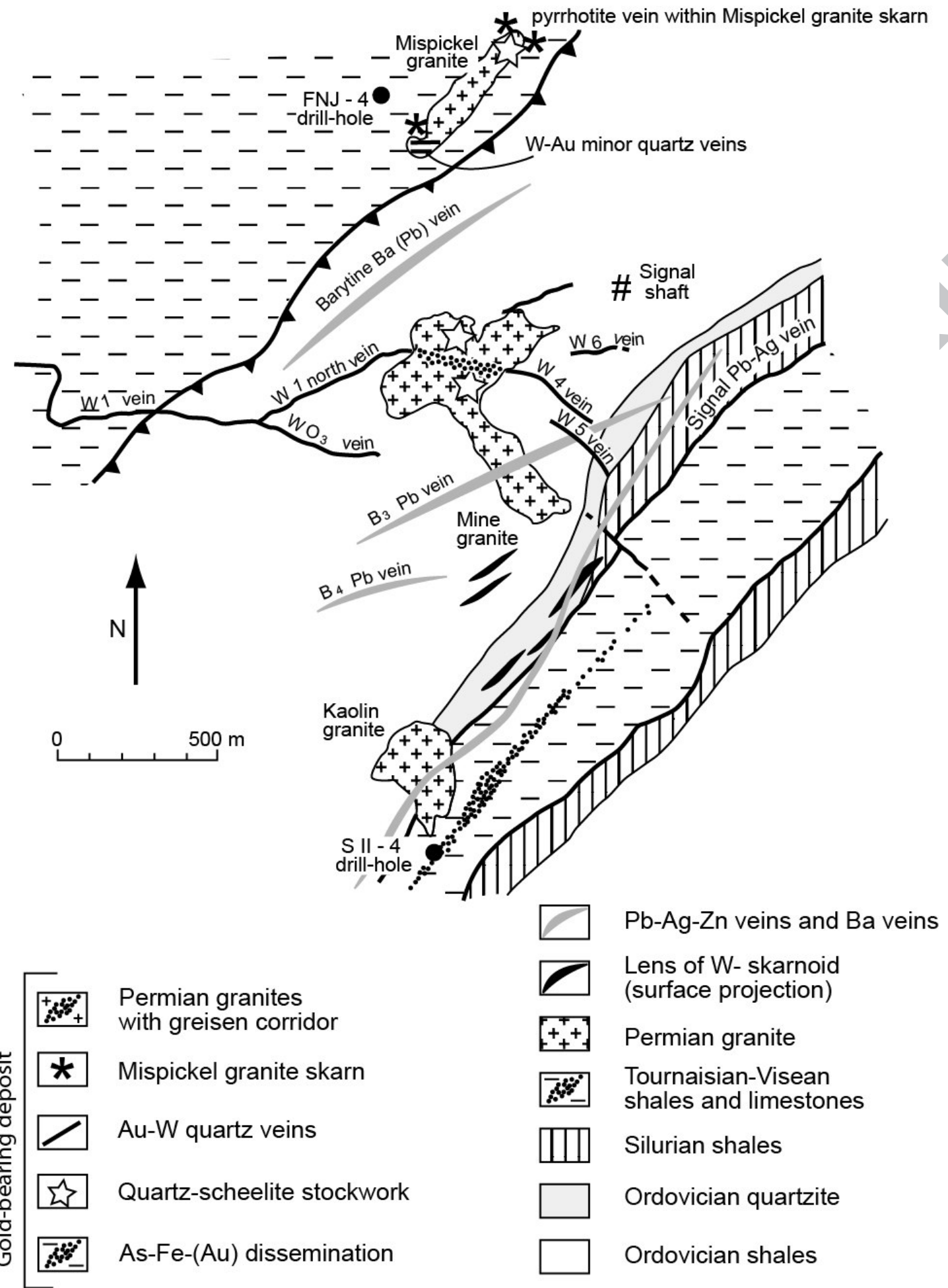

figure $n^{\circ} 2$ 

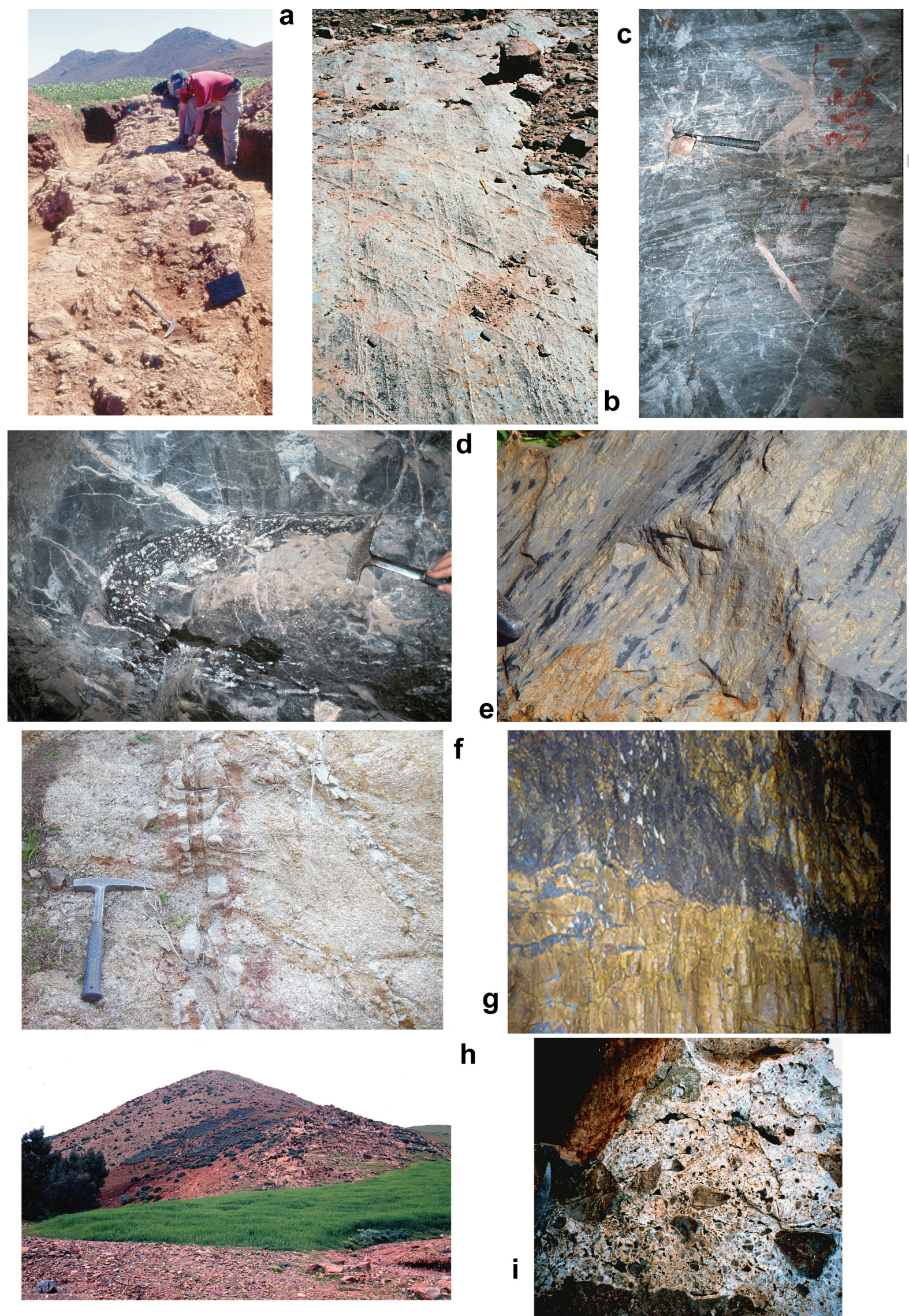


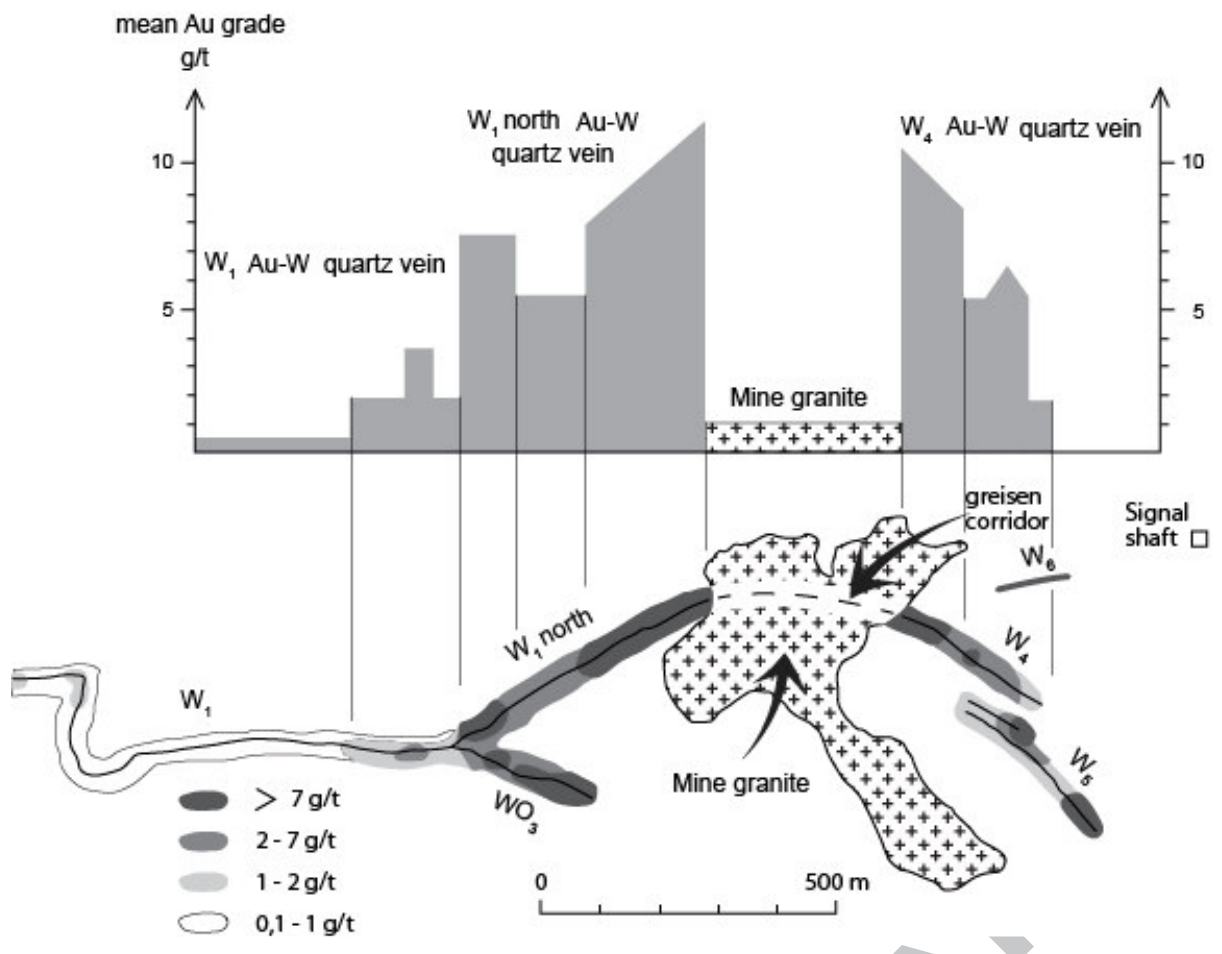




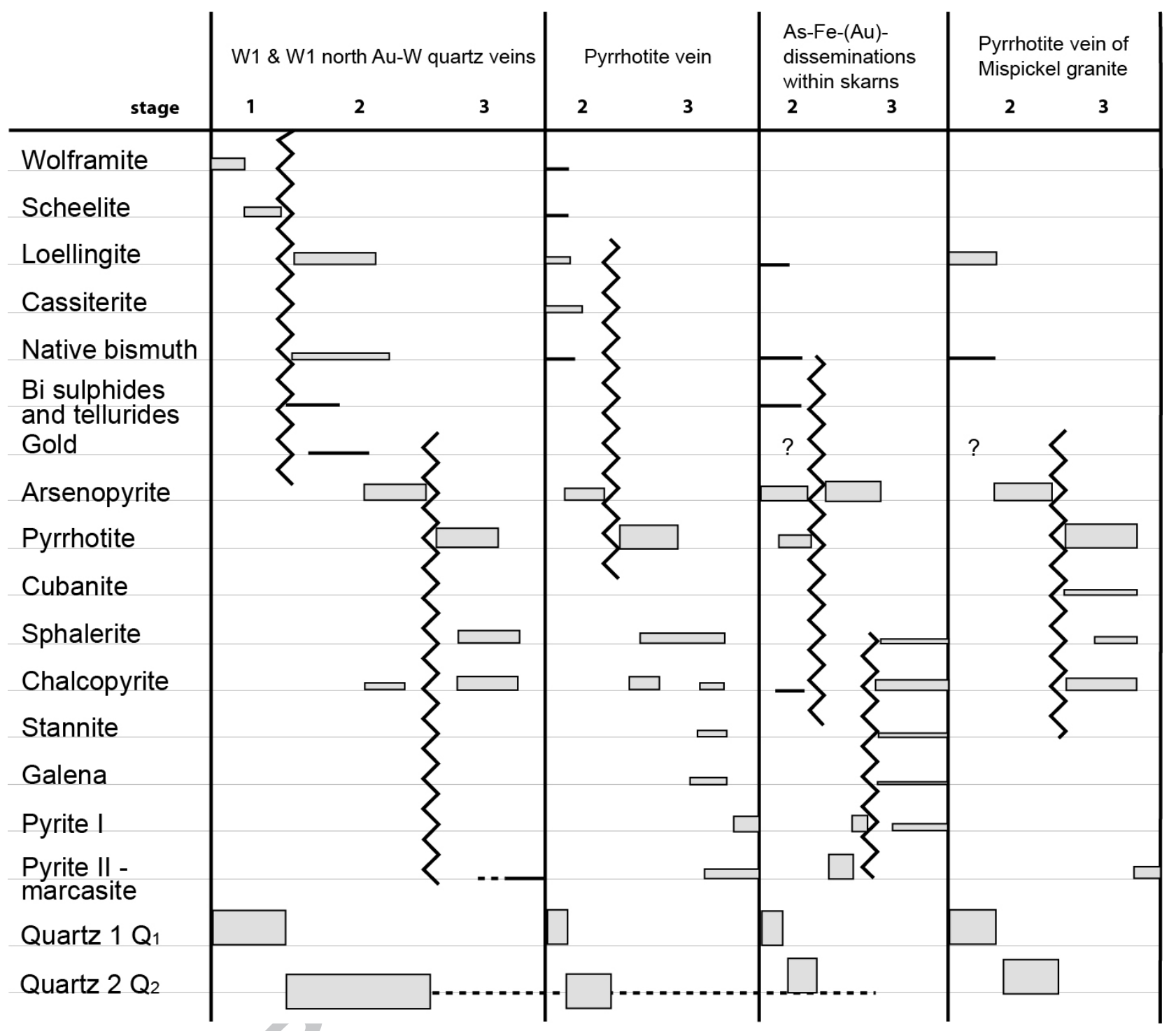




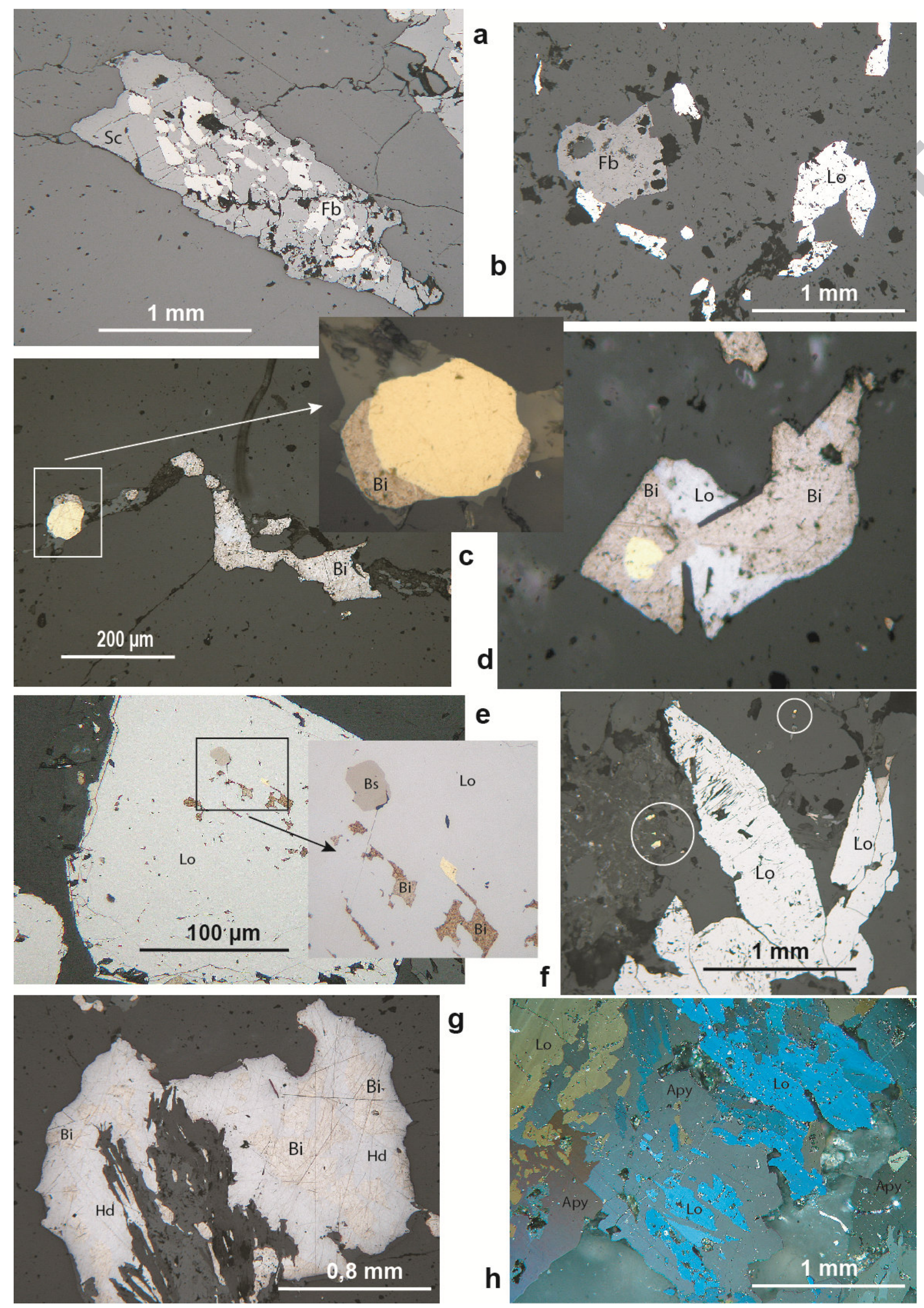



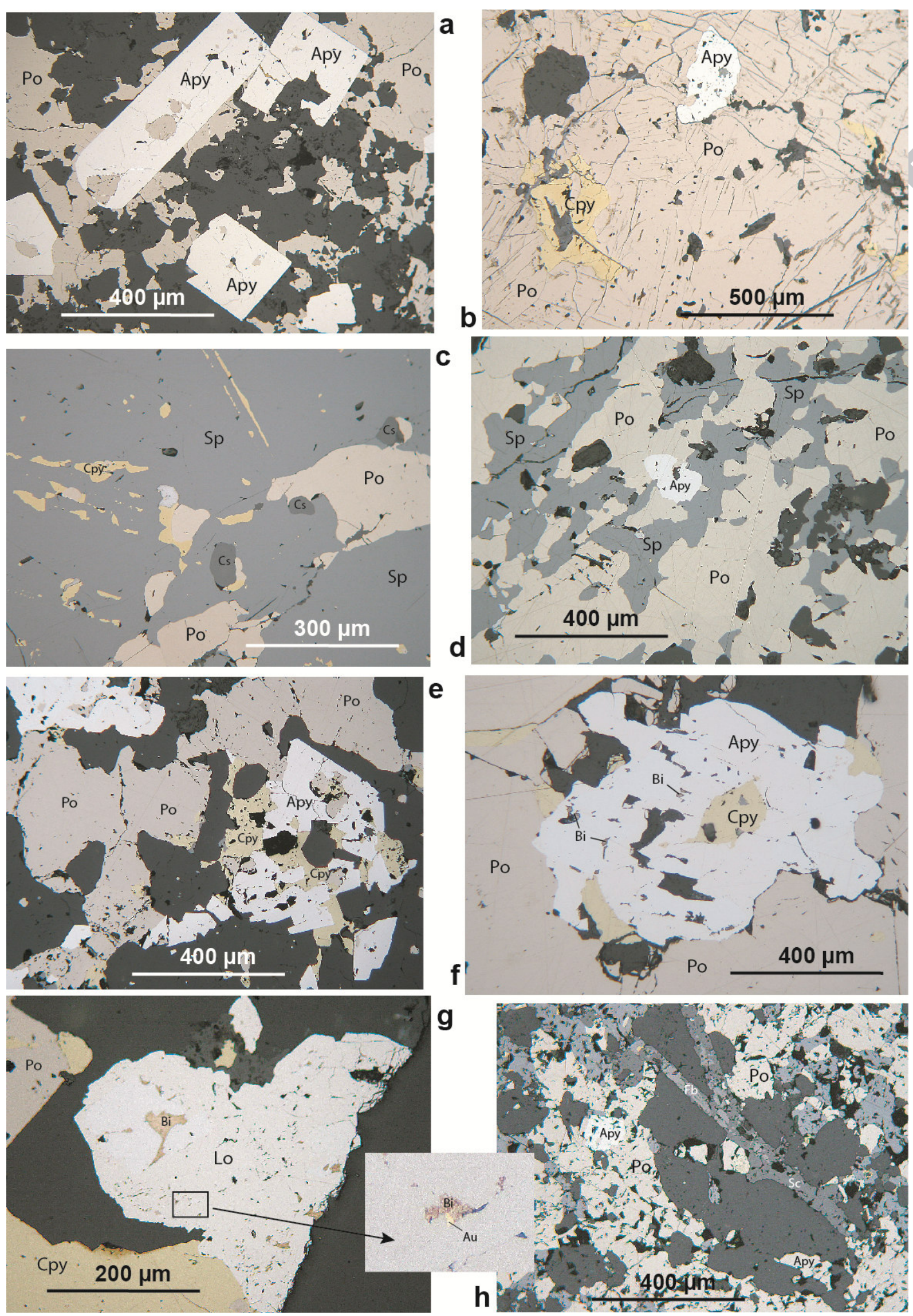

g

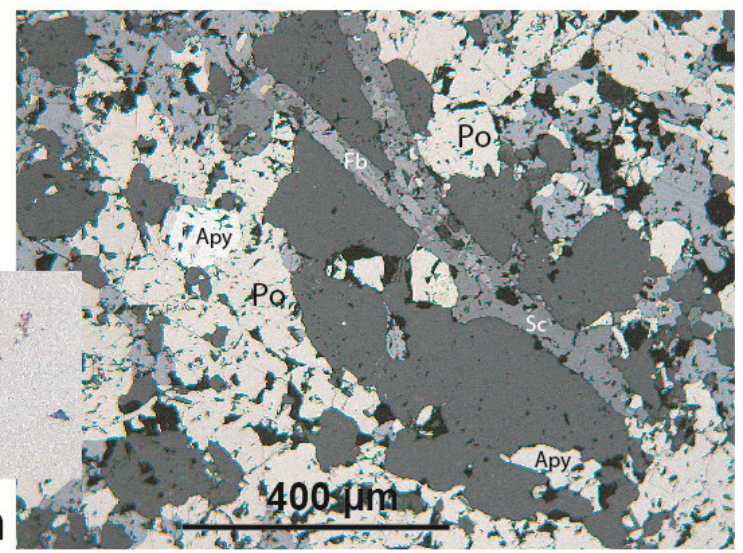




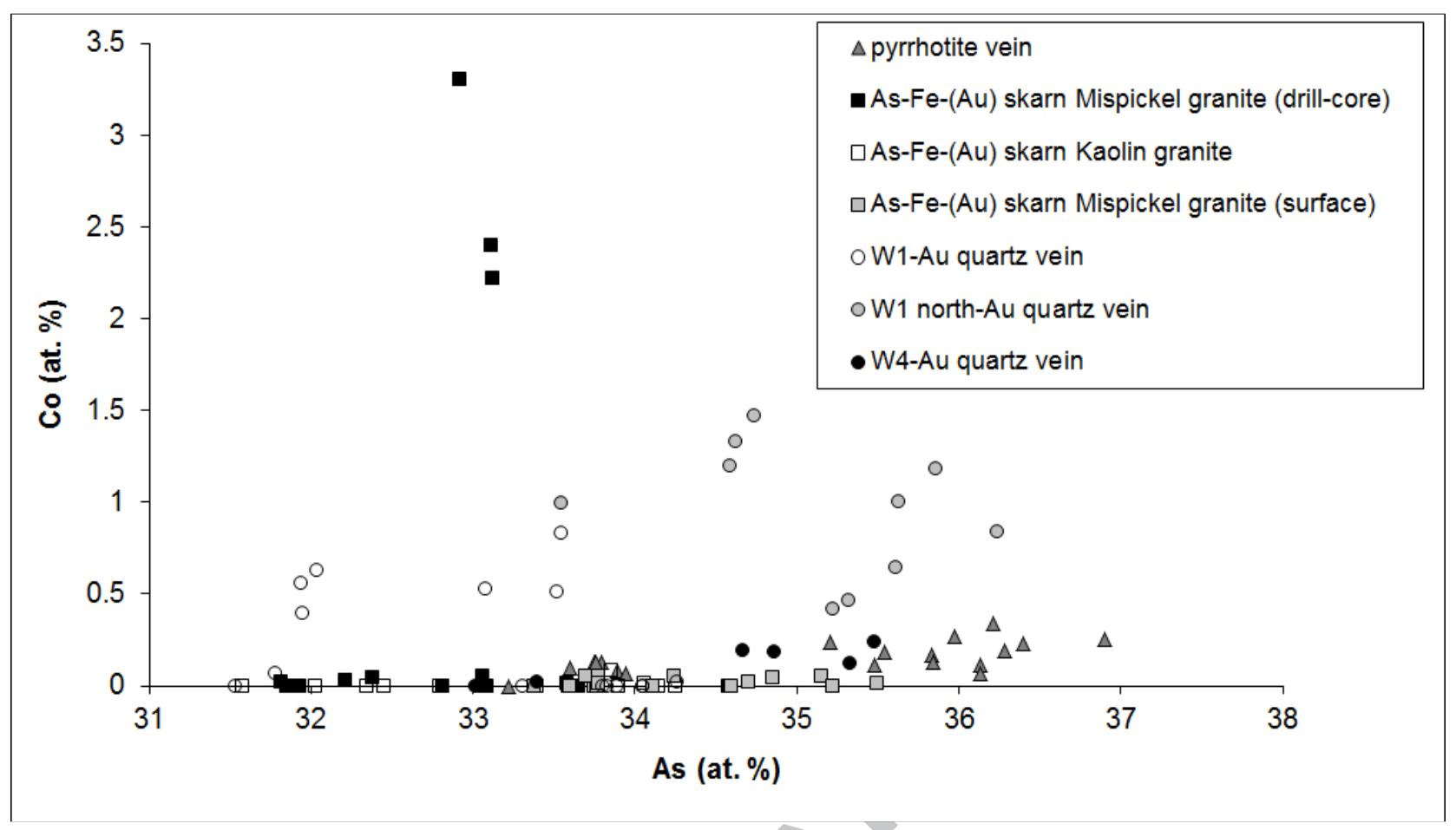




\section{ACCEPTED MANUSCRIPT}
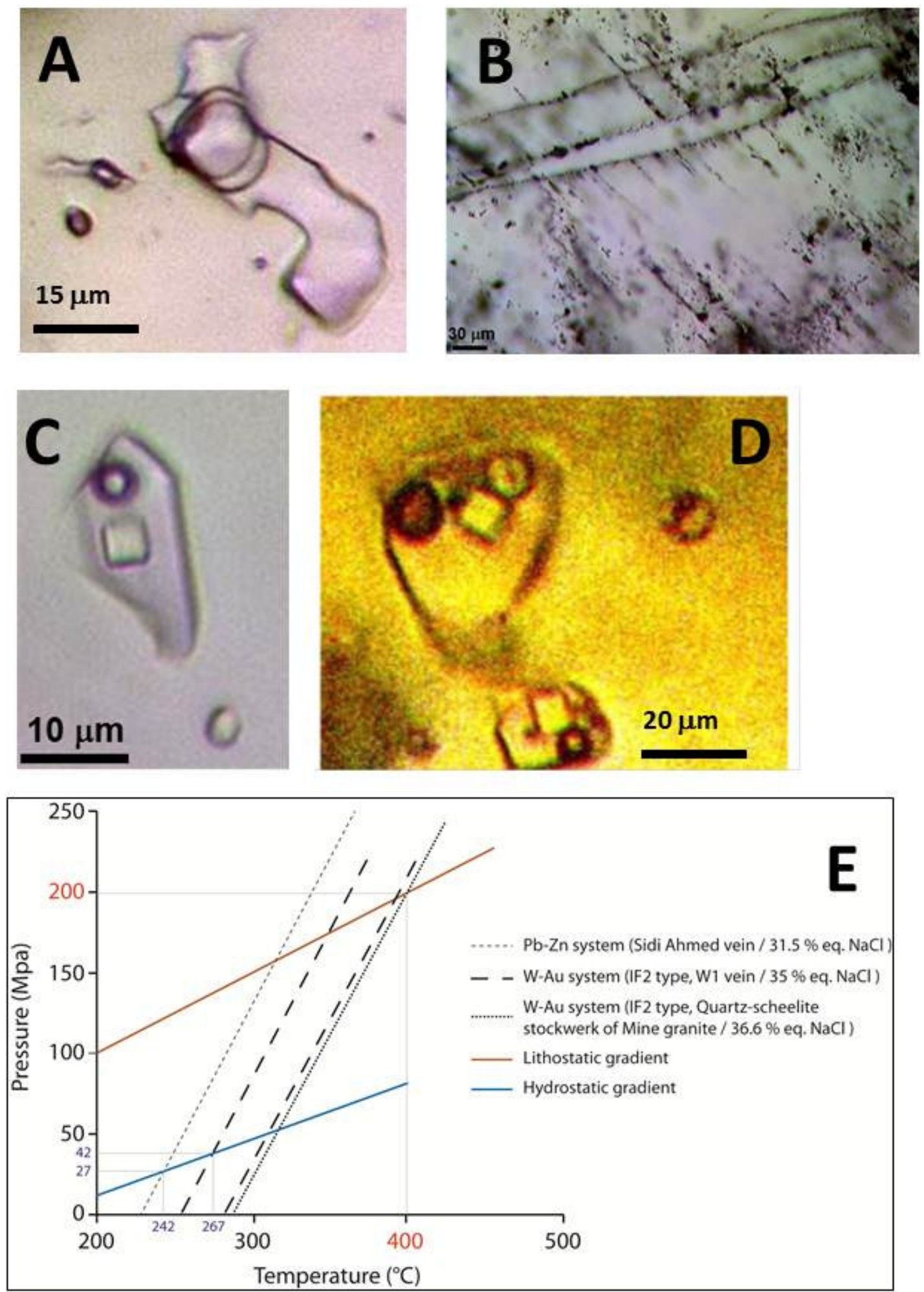


\section{ACCEPTED MANUSCRIPT}
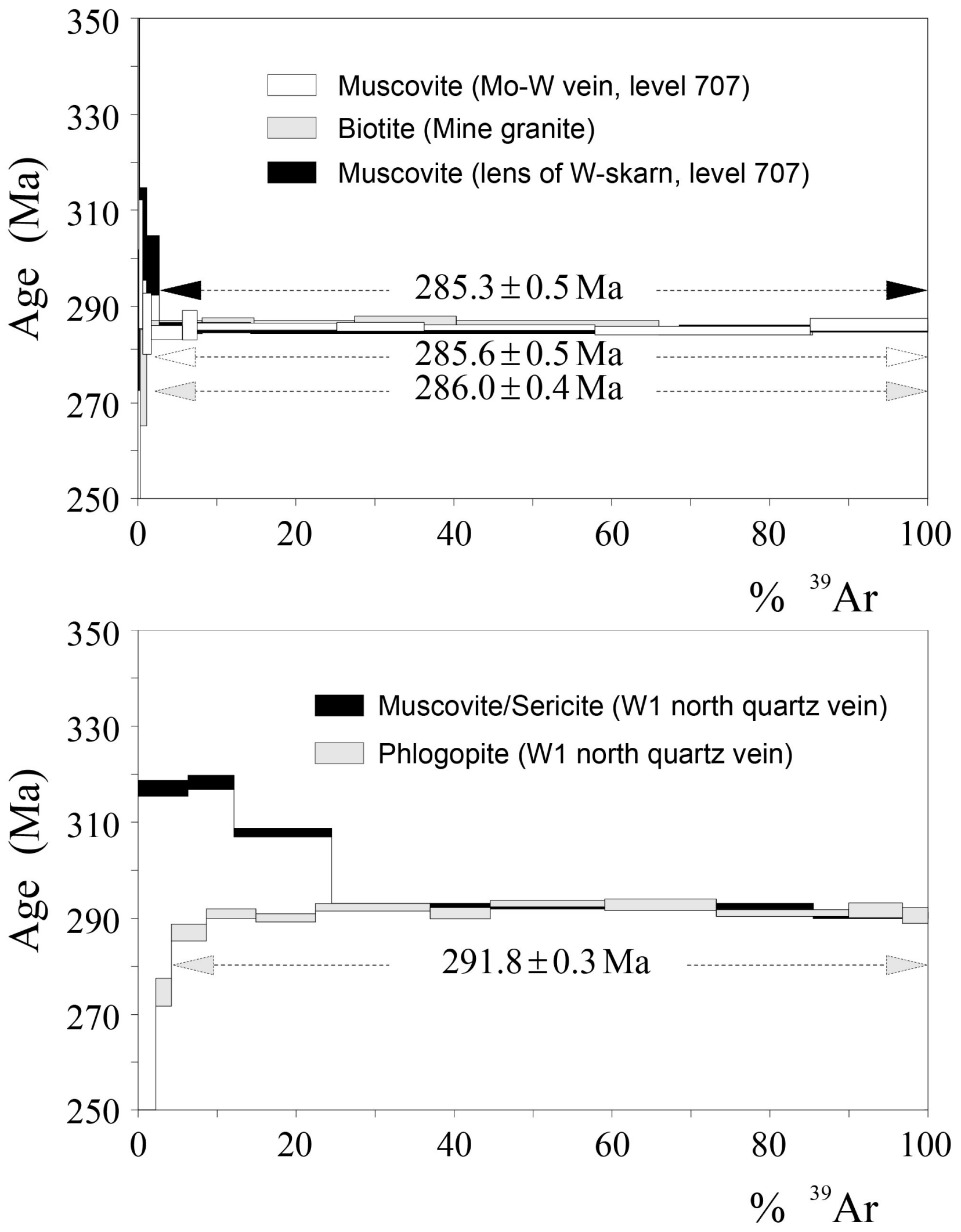


\section{ACCEPTED MANUSCRIPT}
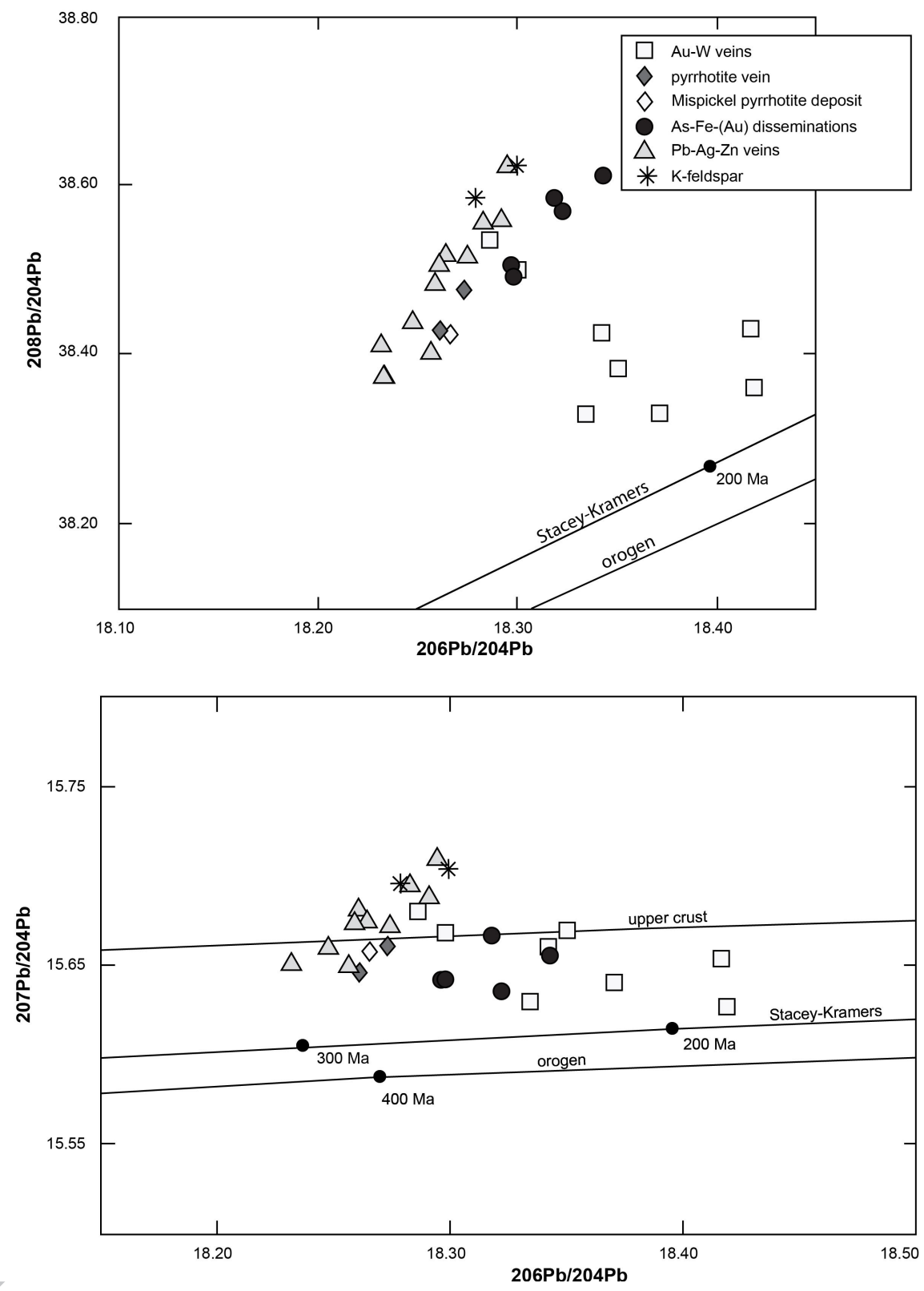

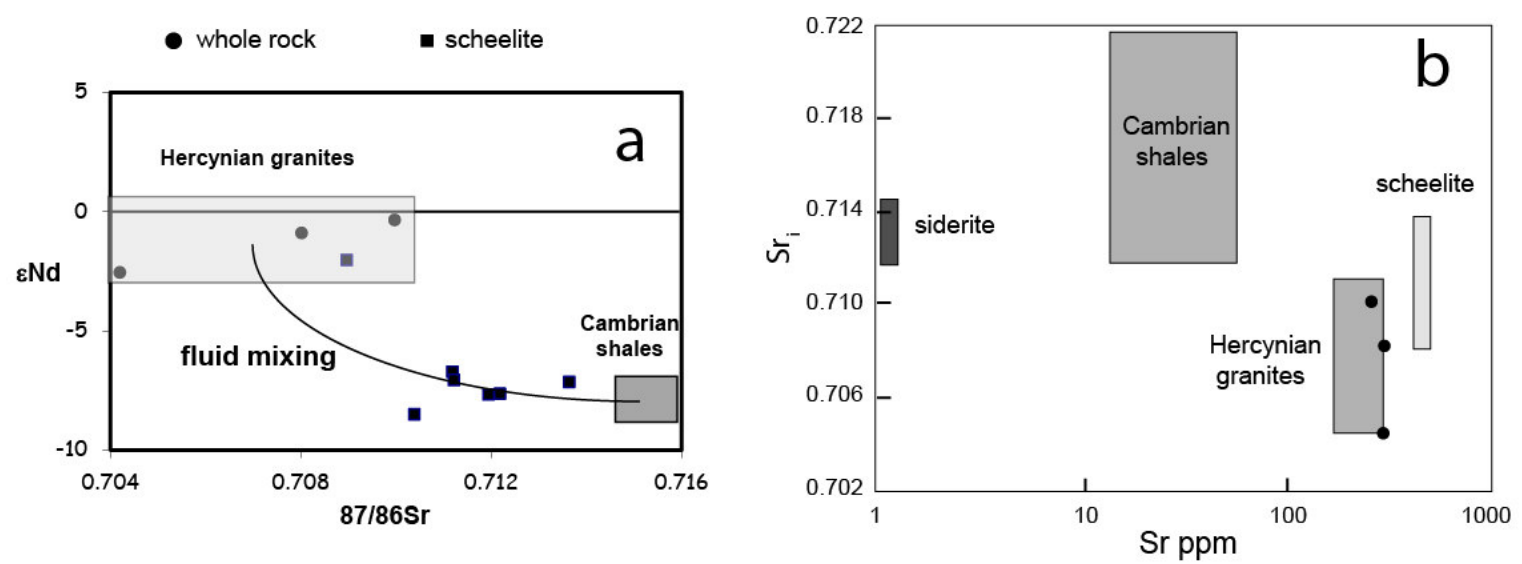

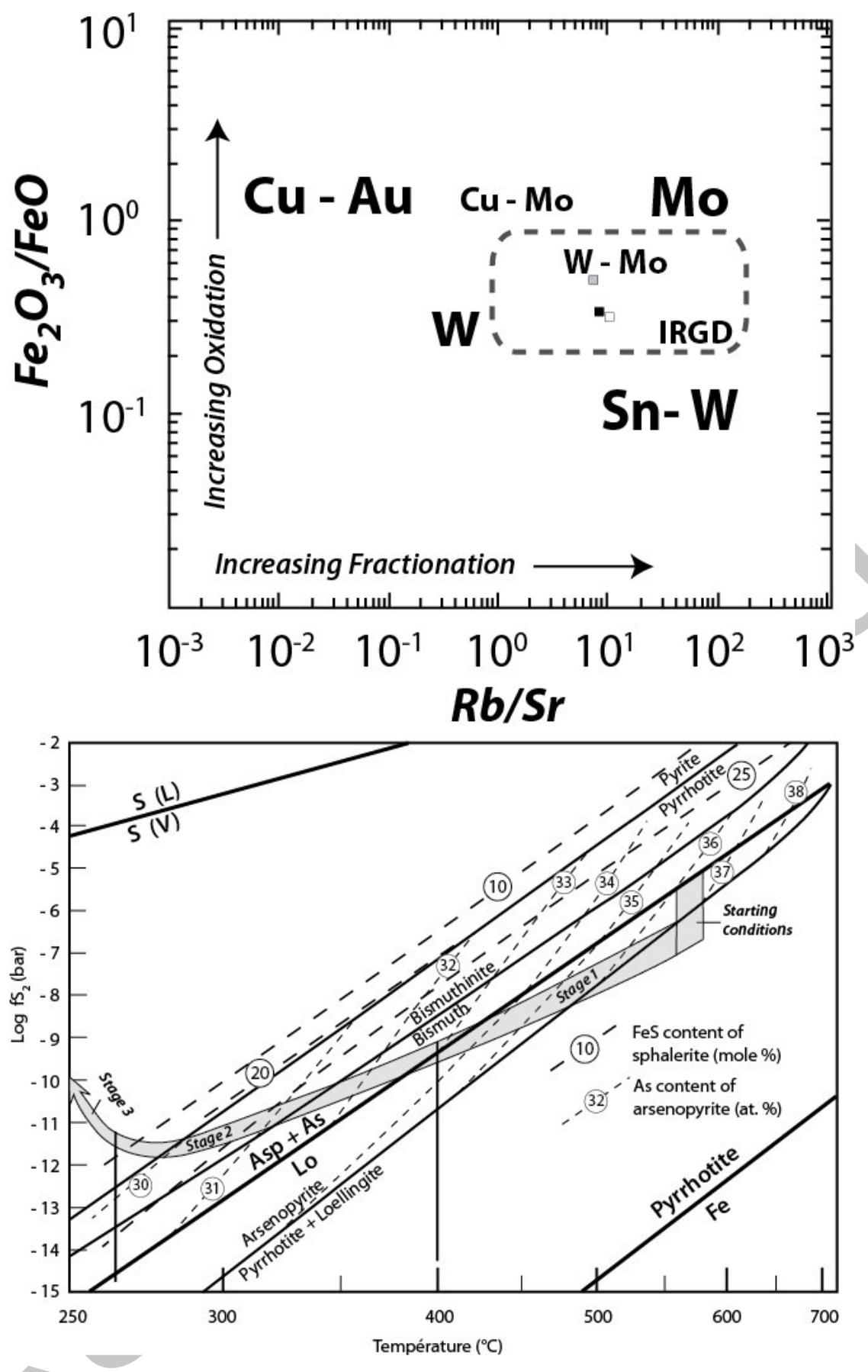
A

(c.a. $292 \mathrm{Ma}$ )

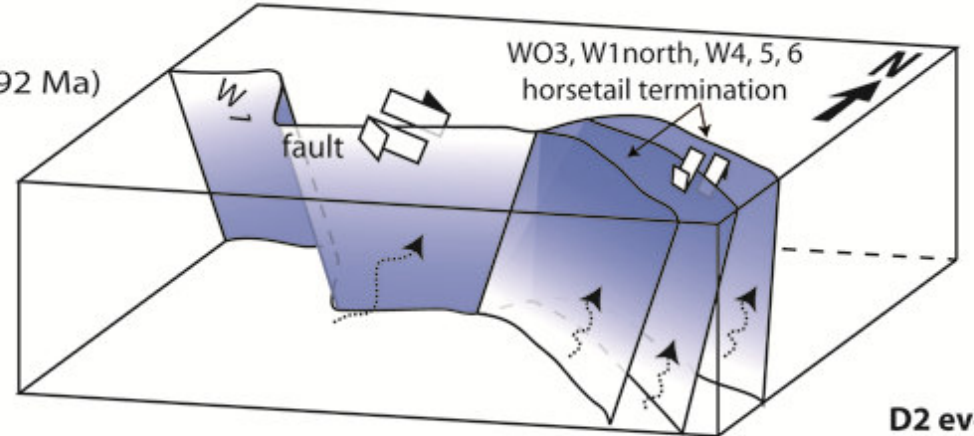

D2 event (right-lateral transtension) (c.a. $286 \mathrm{Ma}$

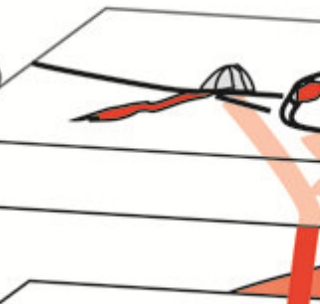

$\sim 5.5 \mathrm{~km}$

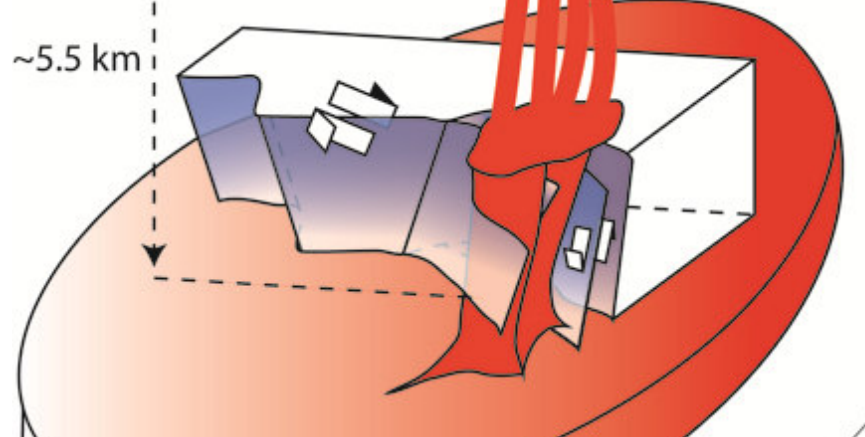

severe D2 incremental

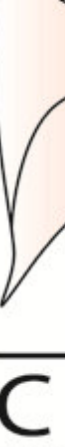

(Late Permian, Triassic?)

\section{D2 event (right-lateral transtension)}

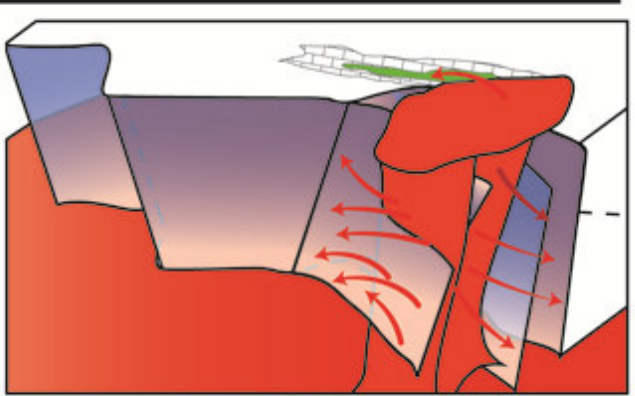

Stage I (W): Quartz1, expulsion from melt of $\mathrm{CO}_{2}$-rich fluids (IF1) (red arrows), lithostatic fluid pressures ( 1.5 kbars), $\sim 580^{\circ} \mathrm{C}$, reduced skarn environement with stratabound lenses (in green).

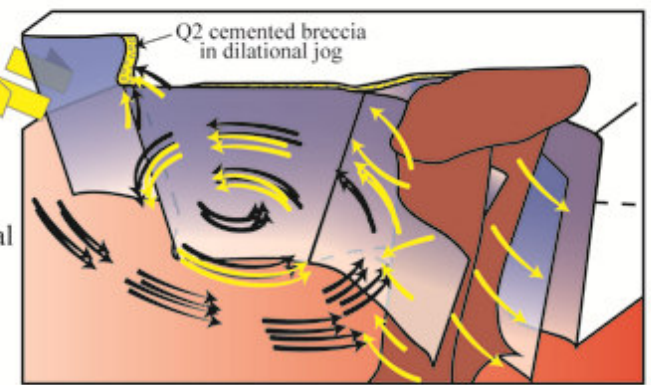

Stage II \&III (Au-As-Bi-Te / Zn-Cu-(Sn)): cooling intrusion, Quartz 2 (yellow), Au-bearing saline $\mathrm{H}_{2} \mathrm{O}$-rich fluids (IF2) expeled from late-crystallization stage of the magma (yellow arrows), hydrostatic fluid pressures ( $\sim 550$ bars), $\sim 300^{\circ} \mathrm{C}$, local scale convection cells with «crustals fluid contibution (black arrows).

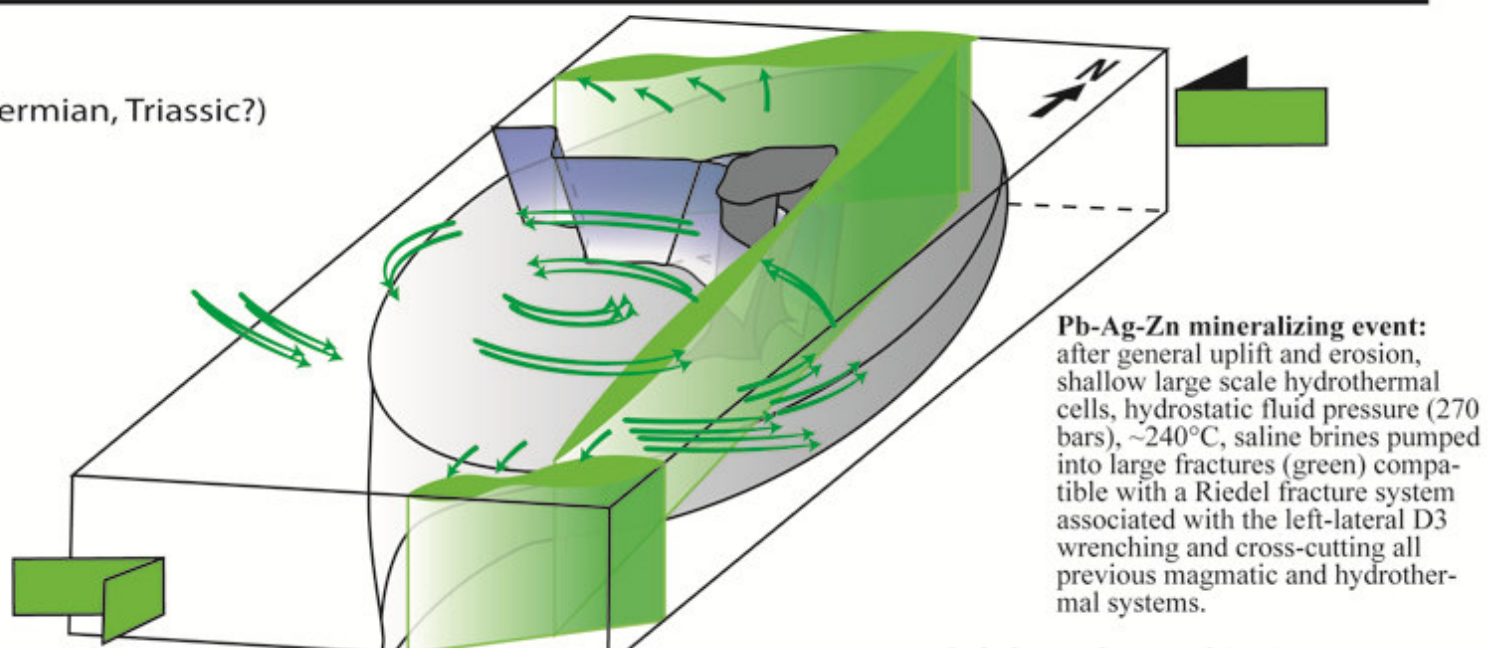

D3 event (left-lateral wrenching) 


\section{Highlights : \\ « Late-Hercynian Intrusion gold-related gold deposits : an integrated model on the Tighza polymetallic district, central Morocco}

Study describes the first R-IRG deposit in North-Africa to our knowledge.

Detailed mineralogical, isotopic $(\mathrm{Pb}, \mathrm{Sr}-\mathrm{Nd})$, chronological and fluid inclusions data are given. Original structural context with pre-granitic corridors explained the shape of the deposits.

3D model is proposed, discarding a genetic relationship of $\mathrm{Pb}-\mathrm{Ag}$ veins with gold deposits. 